FABIAN SÁ

\title{
DISTRIBUIÇÃO E FRACIONAMENTO DE CONTAMINANTES NOS SEDIMENTOS SUPERFICIAIS E ATIVIDADES DE DRAGAGEM NO COMPLEXO ESTUARINO DA BAÍA DE PARANAGUÁ (PR).
}

Dissertação apresentada ao Curso de PósGraduação em Geologia Ambiental do Setor de Ciências da Terra da Universidade Federal do Paraná, como requisito parcial à obtenção dograu de Mestre.

Orientador: Dr. Rodolfo José Angulo

Co-orientadores:

Dr. ${ }^{\text {a }}$ Eunice da Costa Machado

Dr. Nicolai Mirlean 


\title{
TERMO DE APROVAÇÃO
}

\author{
Fabian Sá
}

\section{"DISTRIBUIÇÃO DE ELEMENTOS METÁLICOS NOS SEDIMENTOS SUPERFICIAIS DO COMPLEXO ESTUARINO DA BAÍA DE PARANAGUÁ(PR)".}

Dissertação de Mestrado aprovada como requisito parcial para obtenção do grau de Mestre no Curso de Pós-Graduação em Geologia, área de concentração em Geologia Ambiental, da Universidade Federal do Paraná, Comissão formada pelos Professores:

Professor Doutor Rodolfo José Angulo - UFPR

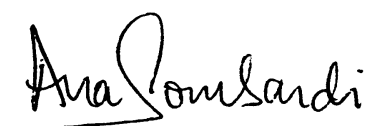

Professora Doutora Ana Tereza Lombardi - UFPR

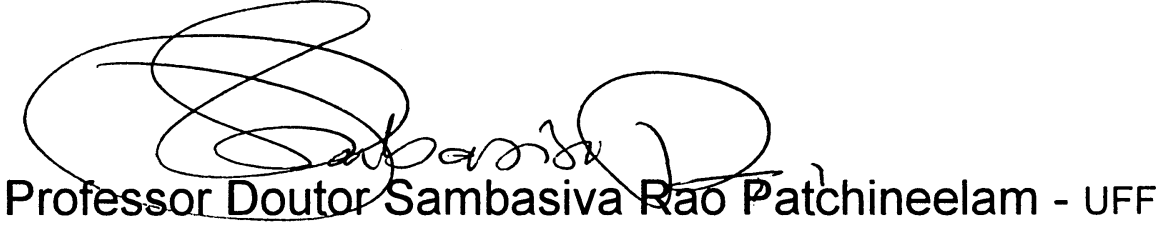

Curitiba, 22 de Abril 2003. 
"Quem tem consciência para ter coragem..." 


\section{Agradecimentos}

À Capes pela concessão da bolsa de estudos.

Ao curso de Pós-graduação em Geologia Ambiental, ao Centro de Estudos do Mar e a Fundação Universidade Federal do Rio Grande pela infra-estrutura.

À indústria de fertilizantes FOSPAR e a APPA (Associação dos Portos de Paranaguá e Antonina), pois sem suas colaborações não seria possível a realização deste trabalho.

À Dra. Eunice C. Machado pela orientação, amizade e constante presença em todos os momentos da dissertação.

Ao Dr. Rodolfo J. Angulo pela orientação, reconhecimento e valorização do projeto inicial. realizadas.

Ao Dr. Maurício Camargo pela grande ajuda nas análises estatísticas

Ao pessoal do Laboratório de Biogeoquímica Marinha, as técnicas Tânia (no início) e Liciane (no fim), os estagiários Kléber, Mariana, Byanka e Adriano (piriquito), em especial à Nilva Brandini pelas grandes ajudas em diversas situações.

Aos colegas do Laboratório de Oceanografia Geológica, Alfredo Araújo, João Carrilho, Marcelo Lamour, Lydio Odreski, Sirlei Guisi (ótimos cafezinhos) e Carlos Soares, pelas contribuições, piadas e risadas de todos os dias.

Aos demais colegas do CEM, André Garraffoni, Ricardo Krull, Cintia, Yargos, Rangel, Michela Carboni ...

À galera do Laboratório de Física Marinha, Maurício (pelos mapas), Luizão, Georgina, e os inflamáveis Murillo e Clécio pelo velho e bom rock'n roll que tocamos nos "pé na areia".

A todo corpo clínico da Clínica Tobias de Macedo (nossa querida replública): Abo, Orlei, Leonardo e Juan pelas festas e diversões que passamos e iremos passar.

Ao pessoal da administração do CEM, Vilminha, Lalá, Rutinha, aos barqueiros Josias, Abraão e Zezé, Raul e Ronei da manutenção.

Aos demais amigos, pois encheria de páginas se escrevesse o nome de cada um, mas estes sabem que estão presentes em minhas lembranças.

Ao meu irmão Gilvan Sá e minha cunhada Karina Salgado, pela compreensão e estadias em Curitiba.

À minha mãe Erna, pelo carinho e atenção que sempre demonstrou em qualquer situação.

$\mathrm{E}$ in memoriam ao meu pai Ivan, que continua iluminando meu caminho. 


\section{SUMÁRIO}

LISTA DE FIGURAS .............................................................

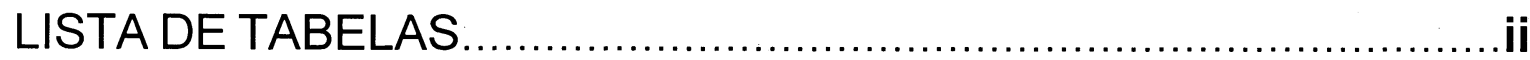

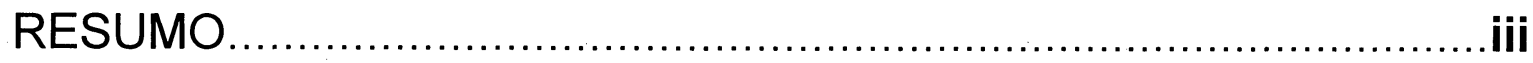

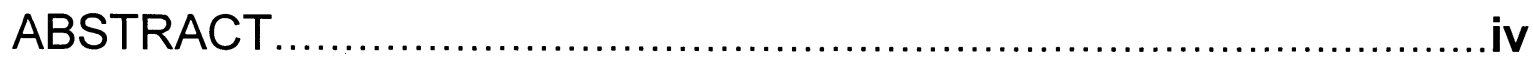

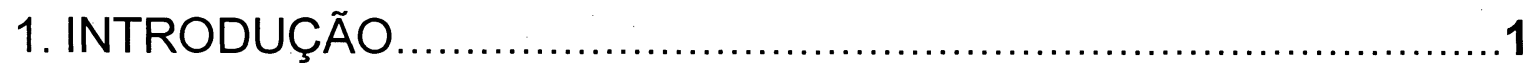

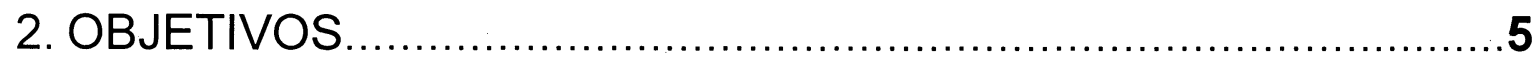

3. CARACTERIZAÇÃO DA ÁREA DE ESTUDO .............................

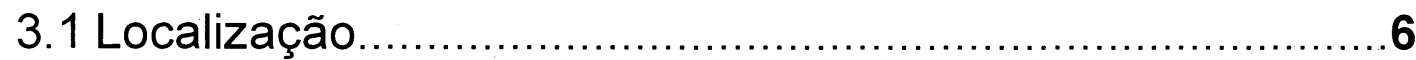

3.2 Caracterização regional e evolução da planície costeira......7

3.3 Clima e características hidrológicas .............................. 7

3.4 Distribuição dos sedimentos de fundo da Baía de

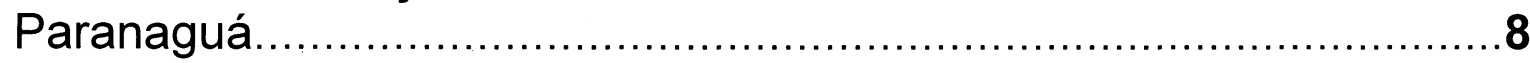

3.5 Aspectos industriais e de impactos ambientais...............10

3.6 Aspectos tecnológicos da dragagem...........................11

3.6.1 Utilização das atividades de dragagem...................11

3.6.2 Tipos de dragas...........................................12

3.7 Dragagens no Complexo Estuarino de Paranaguá...........12

3.7.1 Características técnicas do Porto de Paranaguá.......13

3.7.2 Características técnicas do Porto de Antonina..........13

3.8 Poluição dos sedimentos............................................14

3.9 Processos de ressuspensão.......................................17

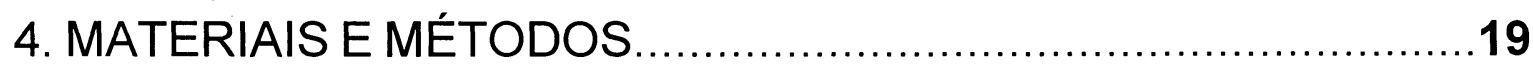

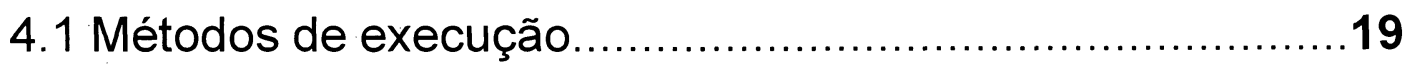

4.2 Instrumentação e métodos de análise de laboratório.........22 
4.3 Tratamento estatístico..............................................23

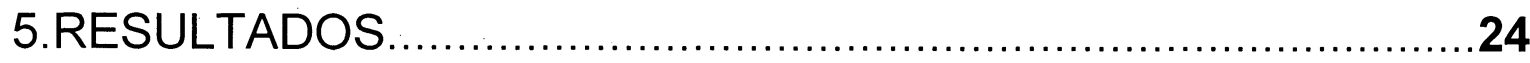

5.1 Avaliação dos impactos das dragagens na área compreendida entre a Baía de Antonina e o Porto de Paranaguá, primeira

etapa .24

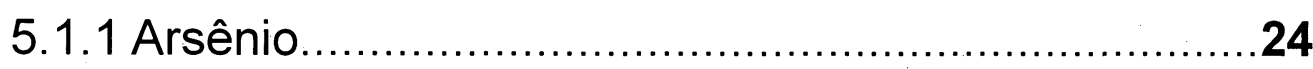

5.1.2 Níquel................................................................

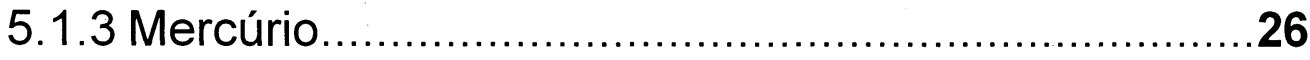

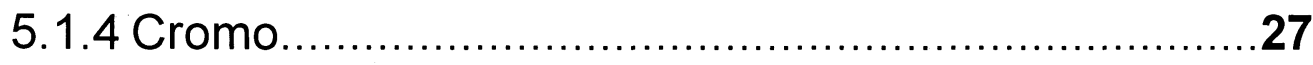

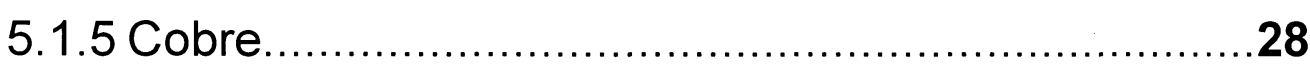

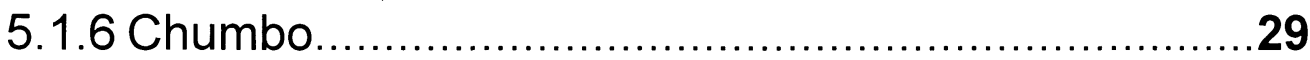

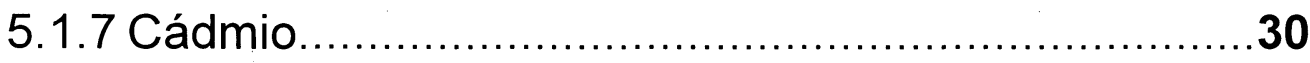

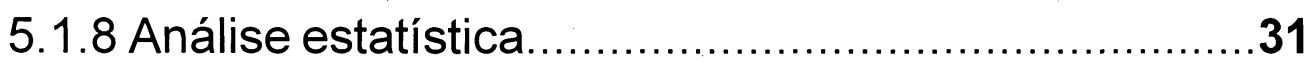

5.2 Avaliação e monitoramento da qualidade do sedimento nas imediações da indústria de fertilizantes FOSPAR - Baía de

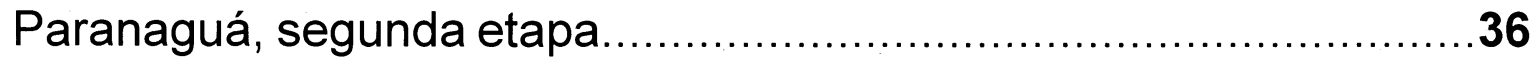

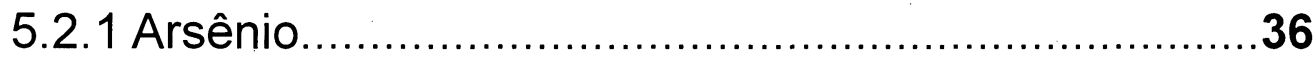

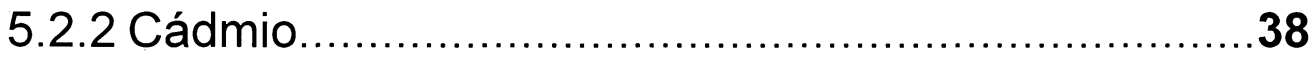

5.2.3 Cromo....................................................... 40

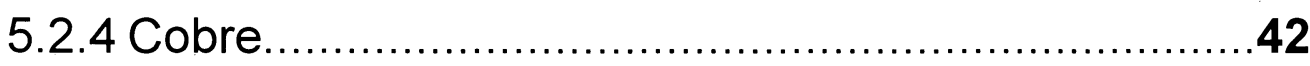

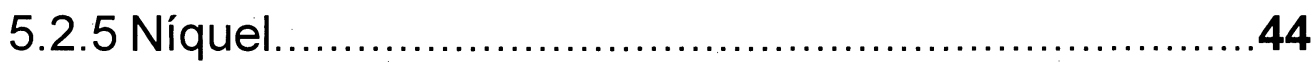

5.2.6 Chumbo.............................................................

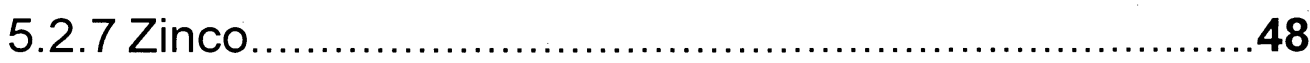

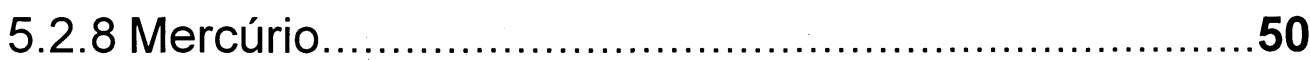

5.2.9 Carbono Orgânico Total......................................51

5.2.10 Análise estatística........................................52 
5.3 Avaliação da qualidade do sedimento na bacia de evolução do porto de Paranaguá, terceira etapa........................................55

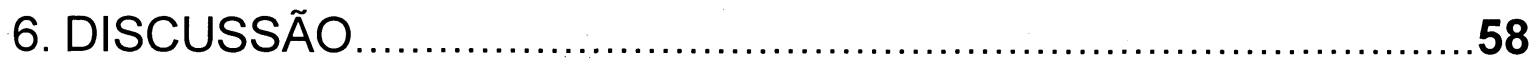

6.1 Elementos metálicos nos sedimentos superficiais............58

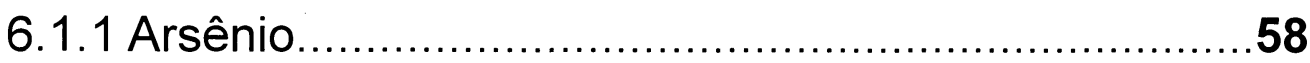

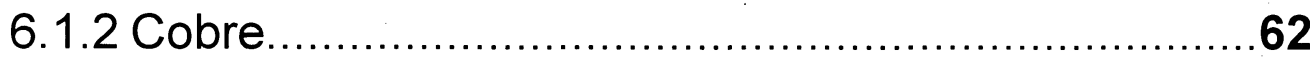

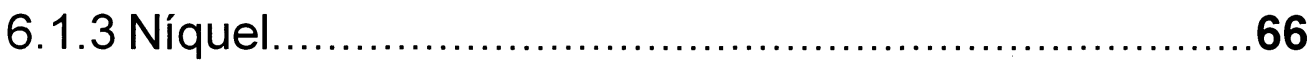

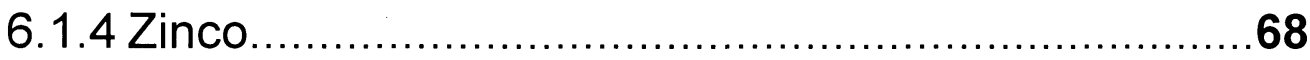

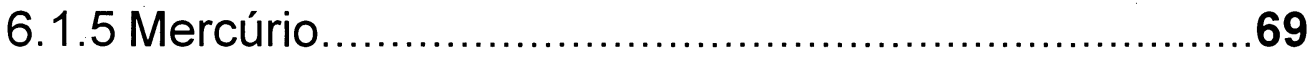

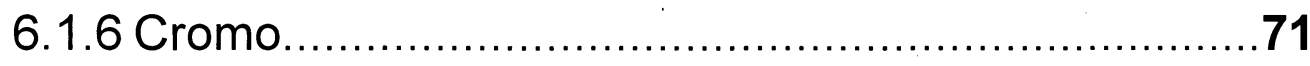

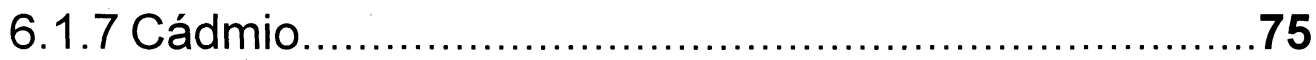

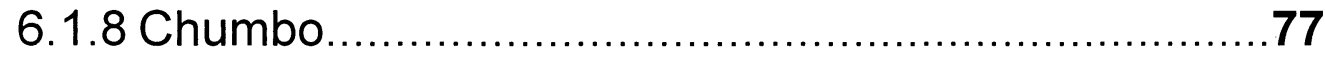

6.2 Legislação Ambiental e atividades de dragagem..............80

6.2.1 Legislação Ambiental...........................................80

6.2.2 Sugestões para monitoramento de dragagem.........82

6.2.3 Estudo de caso: Acompanhamento das atividades de dragagem no canal de acesso ao porto de Antonina......................83

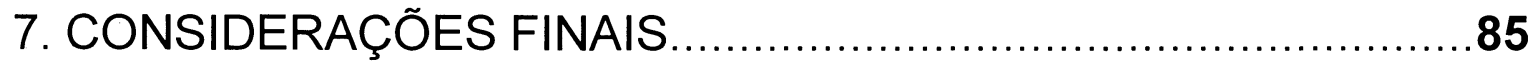

8. REFERÊNCIAS BIBLIOGRÁFICAS ...................................87 


\section{LISTA DE FIGURAS}

Figura 1: Complexo Estuarino da Baía de Paranaguá.

Figura 2 Vista aérea do município de Paranaguá..............................................13

Figura 3: Mapa da localização dos pontos de coleta da primeira etapa...........................20

Figura 4: Mapa da localização dos pontos de coleta da segunda etapa.........................21

Figura 5: Mapa da localização dos pontos de coleta da terceira etapa..........................21

Figura 6: Concentrações de arsênio (ppm) obtidos através de extração total (forte) em amostras de sedimento superficial das estações investigadas nas campanhas Pré-

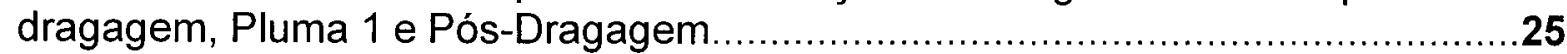
Concentrações de níquel (ppm) obtidos através de extração total (forte) em

Figura 7: amostras de sedimento superficial das estações investigadas nas campanhas Prédragagem e Pós-Dragagem, bem como na campanhas Plumas $1 \ldots \ldots \ldots \ldots \ldots \ldots \ldots .26$ Concentrações de mercúrio (ppm) obtidos através de extração total (forte) em

Figura 8: amostras de sedimento superficial das estações investigadas nas campanhas Pré-

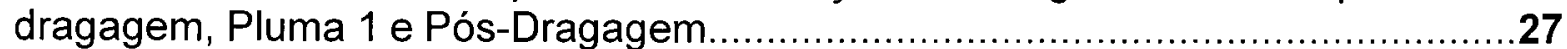
Concentrações de cromo (ppm) obtidos através de extração total (forte) e parcial

Figura 9: (fraca) em amostras de sedimento superficial das estações investigadas nas campanhas Pré-dragagem e Pós-Dragagem, bem como nas campanhas Plumas 1,2 e 3.

Concentrações de cobre (ppm) obtidos através de extração total (forte) e parcial

Figura 10: (fraca) em amostras de sedimento superficial das estações investigadas nas campanhas Pré-dragagem e Pós-Dragagem, bem como nas campanhas Plumas 1,2 e 3. 29

Concentrações de chumbo (ppm) obtidos através de extração total (forte) e parcial

Figura 11: (fraca) em amostras de sedimento superficial das estações investigadas nas campanhas Pré-dragagem e Pós-Dragagem, bem como nas campanhas Plumas 1,2 e 3.

Concentrações de cádmio (ppm) obtidos através de extração total (forte) e parcial

Figura 12: (fraca) em amostras de sedimento superficial das estações investigadas nas campanhas Pré-dragagem e Pós-Dragagem, bem como nas campanhas Plumas 1,2 e 3. 31

Figura 13: Análise de agrupamento (Cluster) relativo à extração fraca. 34

Figura 14: MDS das seções durante as atividades de dragagem relativo à extração fraca....34

Figura 15: Análise de agrupamento (Cluster) relativo à extração forte 35

Figura 16: MDS das seções durante as atividades de dragagem relativo à extração forte.....35

Figura 17: Concentrações de arsênio (ppm) obtidas através de extração total e parcial em amostras de sedimento superficial das 12 estações investigadas. 
Figura 18: Variação temporal das concentrações de arsênio nos sedimento superficiais.

Concentrações de cádmio (ppm) obtidas através de extração total e parcial em amostras de sedimento superficial das 12 estações investigadas.

Figura 20: Variação temporal das concentrações de cádmio nos sedimentos superficiais

Figura 21: Concentrações de cromo (ppm) obtidas através de extração total e parcial em amostras de sedimento superficial das 12 estações investigadas.

Figura 22: Variação temporal dos teores de cromo nos sedimentos superficiais durante o período investigado.

Concentrações de cobre (ppm) obtidos através de extração total e parcial em amostras de sedimento superficial das 12 estações investigadas......

Figura 24: Variação temporal dos teores de cobre nos sedimentos superficiais durante 0 período investigado.

Figura 25: Concentrações de níquel (ppm) obtidos através de extração total e parcial em amostras de sedimento superficial das 12 estações investigadas.

Figura 26: Variação temporal das concentrações de níquel nos sedimentos superficiais.

Figura 27: Concentrações de chumbo (ppm) obtidos através de extração total e parcial em amostras de sedimento superficial das 12 estações investigadas.

Figura 28: Variação temporal das concentrações de chumbo nos sedimentos superficiais....48

Figura 29: Concentrações de zinco (ppm) obtidas através de extração total e parcial em amostras de sedimento superficial das 12 estações investigadas.........................49

Figura 30: Variação temporal das concentrações de zinco nos sedimentos superficiais........50

Figura 31: Concentrações de mercúrio (ppm) obtidos através de extração à vapor frio em amostras de sedimento superficial das 12 estações investigadas.

Figura 32: Variação temporal das concentrações de mercúrio nos sedimentos superficiais...51

Figura 33: Valores das concentrações de carbono orgânico total.

Figura 34: Análise de agrupamento (Cluster) relativo à extração fraca.

Figura 35: MDS das seções durante as atividades de dragagem relativo à extração fraca....53

Figura 36: Análise de agrupamento (Cluster) relativo à extração forte

Figura 37: MDS das seções durante as atividades de dragagem relativo à extração forte.....54

Figura Concentrações dos elementos metálicos analisados na etapa 2, valores Figura 38: apresentados em $\mathrm{mg} / \mathrm{Kg}(\mathrm{ppm})$, obtidos através de extração fraca em amostras de sedimento superficial das 7 estações investigadas.

Figura 39: Distribuição das concentrações de arsênio (ppm) relativo à extração forte na Baía de Antonina e nas cercanias da industria de fertilizantes local. 
Figura 40: Distribuição das concentrações de cobre $(\mathrm{ppm})$ relativo à extração fraca na Baía de Antonina e nas cercanias da industria de fertilizantes local

Figura 41: Distribuição das concentrações de cobre $(\mathrm{ppm})$ relativo à extração forte na Baía de Antonina e nas cercanias da industria de fertilizantes local.

Figura 42: Distribuição das concentrações de níquel $(\mathrm{ppm})$ relativa à extração forte na Baía de Antonina e nas cercanias da industria de fertilizantes local

Figura 43: Distribuição das concentrações de mercúrio $(\mathrm{ppm})$ na Baía de Antonina e nas cercanias da industria de fertilizantes local.

Figura 44: Distribuição das concentrações de cromo $(\mathrm{ppm})$ relativa à extração fraca na Baía de Antonina e nas cercanias da industria de fertilizantes local.

Figura 45: Distribuição das concentrações de cromo $(\mathrm{ppm})$ relativa à extração forte na Baía de Antonina e nas cercanias da industria de fertilizantes local.

Figura 46 Distribuição das concentrações de cádmio $(\mathrm{ppm})$ relativo à extração forte na Baía de Antonina e nas cercanias da industria de fertilizantes local 


\section{LISTA DE TABELAS}

Tabela 1 Qualidade do sedimento na área de influência das atividades do Porto de Paranaguá..............................................................................

Tabela 2 Qualidade do sedimento na área de influência do Porto de Paranaguá...........14

Tabela 3 Fontes de enriquecimento para metais pesados presentes no estuário da Lagoa dos Patos - RS. Modificado de Baisch (1997) ...................................15

Tabela 4 Teores dos elementos traços nos sedimentos superficiais dos pontos 5 e 6 nas fases de pré e pós-dragagem.

Tabela 5 Média das concentrações $(\mathrm{mg} / \mathrm{Kg})$ relativas à extração fraca em todas as seções consideradas (local) antes e depois da atividade de dragagem...........30

Tabela 6 Média das concentrações $(\mathrm{mg} / \mathrm{Kg})$ relativas à extração forte em todas as seções consideradas (local) antes e depois da atividade de dragagem............31

Tabela 7 Análise teste - $t$, relativa à extração fraca, nas diferentes seções da atividade

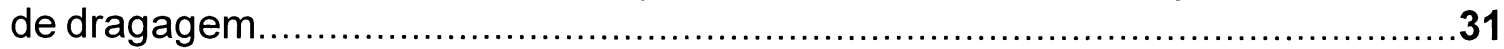

Tabela 8 Análise teste - $t$, relativa à extração forte, nas diferentes seções da atividade de

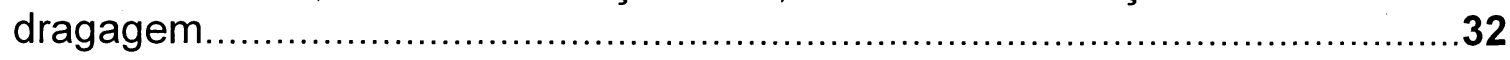

Tabela 9 Qualidade do sedimento na área do estudo, com base nos critérios reportados por Buchman, M.F. 1999.

Tabela 10 Teores para os elementos metálicos investigados expressas em ppm $(\mathrm{mg} / \mathrm{Kg})$ e limites críticos adotados (Buchman M.F.1999). .50 


\begin{abstract}
Most ports require a certain water depth depending on the size of vessels they service. Dredging and disposal of dredged material are sometimes necessary to maintain required water depths in harbours or access channels where shallowing occurs due to sand-drift, delivery of sediment from a river mouth or where breakwaters trap sand This is the case of Paranagua and Antonina harbours. While periodic dredging is required in existing major navigational channels and some smaller channels, disturbance of new areas is minimal. The main concern is that dumping dredged material at the disposal site can introduce toxic substances to the area and can smother estuarine biota. This study aims to investigate contaminant concentrations in two different phases, one strongly and other lightly (more bioavailable) associated to sediment particles of Paranaguá Bay. In this study was addressed not only the impact of dredging activities on the bulk concentration of metal and metalloid but also the effect on the more bioavailable fraction. Moreover, environmental legislation for dredging is also discussed. Three stages have been used in an complementary strategy: 1) Assessment of dredging impacts in the area between Antonina Bay and Paranaguá Harbour, with nine sampling stations; 2) Evaluation and Monitoring of sediment quality close to fertilizer industry (FOSPAR) in the middle sector of Paranagua Bay, with twelve sampling stations; 3) Assessment of sediment quality in the turning basin of Paranaguá Harbour, with seven sampling stations. Superficial sediment samples were taken with a sampler Petit-Ponar. In order to analyse metallic and metalloid elements two extractions were performed, one using $\mathrm{HF}$ and $\mathrm{HNO}_{3}$ with warming and other weak using $\mathrm{HCl} 0.1 \mathrm{~N}$. In each sample arsenic (As), copper $(\mathrm{Cu})$, cadmium $(\mathrm{Cd})$, chromium $(\mathrm{Cr})$, mercury $(\mathrm{Hg})$, nickel $(\mathrm{Ni})$, lead $(\mathrm{Pb})$ e zinc $(\mathrm{Zn})$ were determined by atomic absorption spectroscopy of and cold vapor $(\mathrm{Hg})$. From all analysed elements lead only showed concentrations bellow the critic value, here adopted (Canadian guidelines). High concentrations of $\mathrm{Hg}, \mathrm{Cr}, \mathrm{Cd}$, As and $\mathrm{Ni}$ were registered in Antonina Bay, whereas $\mathrm{Cu}, \mathrm{Zn}, \mathrm{As}$ and $\mathrm{Ni}$, dominated in Paranaguá Bay. Until now, only analyses of bulk concentration of metallic elements in superficial sediments are required by state public authorities for environmental impact studies. As demonstrated here, however, only two extractions are still insufficient for a comphreensive assessment of the dynamics of metallic element, their potential toxicity and to support disposal management of dredged material.
\end{abstract}

Keywords: Dredging, contaminated sediments, Paranaguá Bay, Antonina Bay, environmental monitoring 


\section{Resumo}

As obras de dragagem são essenciais para o desenvolvimento e a manutenção da navegação oceânica e fluvial, para o gerenciamento de outros usos, bem como para a recuperação de ambientes aquáticos. A remoção e disposição final dos sedimentos dragados representam uma parte importante em todo o gerenciamento hídrico. Diferentemente dos trabalhos que verificam o impacto de dragagens, esta pesquisa se distingue por investigar a presença dos elementos químicos em duas frações distintas, uma fracamente ligada e considerada como de maior biodisponibilidade, e outra fortemente ligada às partículas do sedimento. Com isso, é mostrado não somente o efeito da dragagem na concentração total dos metais e metalóide no sedimento, mas também, como a dragagem influencia a fração considerada atualmente de maior biodisponibilidade e toxicidade. Outro aspecto abordado trata da polêmica entre a legislação ambiental e as atividades de dragagem. O estudo foi realizado em três etapas complementares: 1) Etapa 1 Avaliação dos impactos das dragagens na área compreendida entre a Baía de Antonina e o Porto de Paranaguá, com 9 estações amostrais; 2) Etapa 2 Avaliação e monitoramento da qualidade do sedimento nas imediações da indústria de fertilizantes FOSPAR - Baía de Paranaguá, com 12 estações amostrais; 3) Etapa 3 - Avaliação da qualidade do sedimento na bacia de evolução do porto de Paranaguá, com 7 estações amostrais. As amostras foram coletadas com auxílio de um buscador de fundo tipo Petit-Ponar. Foram realizadas duas extrações de elementos metálicos, uma extração forte utilizando $\mathrm{HF}$ e $\mathrm{HNO}_{3} \mathrm{com}$ aquecimento, e outra extração fraca com a utilização de $\mathrm{HCl} 0,1 \mathrm{~N}$. Em cada amostra foram determinados os teores de arsênio (As) e metais cobre $(\mathrm{Cu})$, cádmio $(\mathrm{Cd})$, cromo $(\mathrm{Cr})$, mercúrio $(\mathrm{Hg})$, níquel $(\mathrm{Ni})$, chumbo $(\mathrm{Pb})$ e zinco $(\mathrm{Zn})$ pelo método de espectrofotometria de absorção atômica e vapor frio $(\mathrm{Hg})$. De todos os elementos analisados no presente estudo, apenas o chumbo não apresentou concentrações acima do limite crítico adotado (Legislação Canadense), enquanto os elementos arsênio, cobre, níquel, zinco, mercúrio, cromo e cádmio apresentaram concentrações elevadas. Na Baía de Antonina, foram encontradas concentrações elevadas de mercúrio, cromo, cádmio, arsênio e níquel, enquanto que na Baia de Paranaguá dominaram os elementos cobre, zinco, arsênio e níquel. Até hoje as análises requisitadas pelos órgãos ambientais em estudos e relatórios ambientais relativos à elementos metálicos, são feitas com 1 tipo de extração, a extração forte (concentração total). Como ficou demonstrado neste estudo, utilizar-se de somente os dois tipos de extrações para análises de metais proporciona apenas uma compreensão débil da dinâmica dos elementos metálicos e não gera subsídios suficientes para determinar qual a potencialidade poluidora do local e qual o melhor destino para o material dragado.

Palavres-chave: Atividades de dragagem, Elementos metálicos, Baías de Paranaguá e Antonina, Monitoramento Ambiental. 


\section{INTRODUÇÃO}

O Complexo Estuarino da Baía de Paranaguá é de grande importância para o ecossistema costeiro e desenvolvimento econômico e social do estado do Paraná, uma vez que constitui um espaço geográfico propício a instalações portuárias, industriais, atividades pesqueiras (local de reprodução e crescimento de espécies de interesse comercial) e turísticas. A região da Baía de Antonina, situada na porção mais interna do Complexo Estuarino da Baía de Paranaguá, vem sofrendo reativação de instalações portuárias através do arrendamento de partes das áreas do Porto de Antonina a empresas privadas. Portanto, essa região está submetida aos efeitos impactantes da atividade portuária, atividade urbana e principalmente da atividade industrial.

Com o aumento das atividades portuárias na região, surgiu a necessidade de aumento da profundidade dos canais de acesso ao porto de Paranaguá, havendo consequentemente, dragagens periódicas para a manutenção do calado.

A região de Paranaguá sempre serviu de porta de entrada para mercadorias e aventureiros, tendo sido o principal pólo político do Estado do Paraná até a formação da Vila de Curitiba. Paranaguá sempre manteve sua vocação portuária, apesar de ter havido grande concorrência com o Porto de Antonina no final do século XIX e início do século XX. Situada na poção mais interna da Baía de Paranaguá, Antonina passou a ter maior importância econômica no aspecto portuário do que Paranaguá, tendo localização mais próxima de Curitiba e equipamentos mais sofisticados. Neste período, os principais produtos comercializados eram a madeira, a erva-mate e banana.

Em 1872 um novo projeto foi desenvolvido para o Porto de Paranaguá e com a construção da estrada de ferro Curitiba-Paranaguá, entre 1880-1885, o movimento do Porto de Antonina começou a decrescer. A construção do Porto de Paranaguá começou em 24 de novembro de 1926, e a sua inauguração deu-se em 17 de março de 1933. Atualmente, este porto é economicamente o maior da região sul do Brasil, atuando principalmente na exportação de grãos, sendo também utilizado pelo Paraguai. No que diz respeito à costa brasileira, a localização do Porto de Paranaguá é privilegiada, pois o coloca de forma 
estratégica, permitindo distâncias mínimas de acesso a grandes centros produtores.

Para a avaliação de riscos ambientais e elaboração de planos de gerenciamento de ecossistemas costeiros, tais como o Complexo Estuarino da Baía de Paranaguá, faz-se necessária a investigação da carga de poluentes e de suas características físicas, químicas e biológicas. Para tais estudos, a utilização dos sedimentos apresenta algumas vantagens com relação ao meio hídrico. Por exemplo, os sedimentos correspondem a um dos segmentos ambientais mais estáveis em termos físicos e químicos. Por esta razão, seus parâmetros de qualidade química são ótimos indicadores da qualidade ambiental. Além disso, em virtude dos processos de sedimentação, os sedimentos constituem um registro temporal da contaminação, tanto passada como também recente, além de favorecer estimativa de índices de referência ou níveis de base (background) geoquímico para elementos e compostos não voláteis, tais como os metais. Sua importância reside, ainda, no fato de que os sedimentos são indicadores da qualidade das águas que os circundam (BAISCH, 1994).

Os metais são naturalmente encontrados na maior parte dos diferentes segmentos integrantes dos sistemas aquáticos naturais, tais como rochas, solos, sedimentos, águas e organismos. Contudo, o aumento da concentração destes elementos devido às atividades antrópicas, associado com seu elevado potencial tóxico, podem provocar efeitos adversos aos ecossistemas aquáticos e ao homem (Salomons \& Forstner, 1984), como já ficou demonstrado à humanidade através das doenças de Itai-Itai e doença de Minamata, ambas no Japão (KOBAYASHI, 1970; HARADA, 1978). Em termos de contaminação ambiental, os metais apresentam um risco adicional em relação à maior parte dos contaminantes de origem orgânica, pois eles não sofrem degradação, sendo apenas transferidos de um compartimento ambiental para outro.

Em ambientes aquáticos, a distribuição de elementos e compostos químicos, contaminantes ou não, é controlada por processos químicos, físicos e biológicos, que em última análise determinam sua concentração na coluna de água, nos sólidos suspensos e nos sedimentos. A remoção dos metais da coluna de água e sua deposição nos sedimentos depende portanto de fatores 
como floculação, condições de pH, condições redox, interação com materiais particulados e dissolvidos, orgânicos e inorgânicos (BENNETT, 1987).

Uma vez nos sedimentos, os elementos e compostos químicos podem ser remobilizados para a coluna de água adjacente. A liberação desses compostos pode ser ocasionada por modificações das condições físicoquímicas ambientais, tais como $\mathrm{pH}$, potencial redox, complexos orgânicos e potencial iônico. Nesta situação os sedimentos atuam como fonte de contaminantes (SALOMONS \& FORSTNER, 1984; FORSTNER, 1987; SALOMONS et al., 1988). A hidrodinâmica local é importante quimicamente, pois relaciona-se diretamente com o potencial redox. A perturbação do sedimento pode ocorrer por diversos fatores, tanto de ocorrência natural como ondulações, movimentos turbulentos da água e atividades dos organismos bentônicos (bioturbação), quanto antrópicos como tráfico de navios e trabalhos de dragagens.

As atividades de dragagem, independente do tipo de draga utilizada, causa a ressuspensão do sedimento, modificando suas condições químicas. Esta situação gera a liberação de elementos químicos na coluna de água, aumentando seu potencial de biodisponibilidade. Os metais e metalóides estão presentes nos sedimentos em diversas formas, mas principalmente ligados a sulfetos, os quais quando remobilizados pela atividade de dragagem são oxidados rapidamente liberando esses metais na coluna de água, tormando-os mais disponiveis.

Uma contaminação ambiental ocasionada por metais não está sujeita a processos de biodegradação. Isto significa que, uma vez no ambiente, os metais tendem a sofrer acúmulo, um problema ambiental sem precedentes devido à toxicidade da grande maioria destes elementos.

A ação tóxica dos metais é primariamente o resultado de sua afinidade por grupos quelantes em moléculas biológicas (VALLEE \& ULMER, 1972). Nos seres vivos, incluindo o Homem, os metais reagem com átomos doadores de enxofre das proteínas, resultando em desativação enzimática. Além disso, competem com elementos essenciais tais como cálcio e magnésio e assim desestabilizam a estrutura de biomoléculas, resultando em efeitos tóxicos e até carcinogênicos (NAS, 1977). Assim, a toxicidade de um metal e/ou metalóide 
(arsênio) depende não só de sua concentração no organismo, mas também da fração que realmente atinge os sítios ativos no sistema biológico.

No ambiente, um elemento químico pode ser encontrado em diversas formas ou espécies químicas, consequentemente sua concentração total tem pouca, ou nenhuma, relação com sua disponibilidade biológica. Tanto mais biodisponivel será um elemento, quanto maior facilidade para penetrar em membranas biológicas este apresentar. Com isso, tem-se que espécies fracamente ligadas, ou lábeis, íons livres e íons ligados a moléculas orgânicas pequenas e de baixa polaridade são as formas de maior biodisponibilidade.

Este trabalho procurou identificar o efeito de processos de dragagem na distribuição de alguns elementos químicos, dentre eles metais e metalóide (arsênio), em sedimentos superficiais do Complexo Estuarino da Baía de Paranaguá. Diferentemente da maioria dos trabalhos que verificam o impacto de dragagens, esta pesquisa se distingue por investigar a presença dos elementos químicos em duas frações distintas, uma fracamente ligada e considerada como de maior biodisponibilidade, e outra fortemente ligada às partículas do sedimento. Com isso, é mostrado não somente o efeito da dragagem na concentração total dos metais e metalóide no sedimento, mas também, como a dragagem influencia a fração considerada atualmente de maior biodisponibilidade e toxicidade. 


\section{OBJETIVOS}

\subsection{Objetivo geral}

Investigar o grau de contaminação por elementos metálicos nos sedimentos superficiais do Complexo Estuarino da Baía de Paranaguá.

\subsection{Objetivos específicos}

- Analisar a influência da atividade de dragagem na distribuição dos elementos metálicos nos sedimentos superficiais;

- Identificar quais destes elementos metálicos $\mathrm{Al}, \mathrm{As}, \mathrm{Cd}, \mathrm{Cr}, \mathrm{Cu}, \mathrm{Fe}, \mathrm{Mn}, \mathrm{Pb}$, $\mathrm{Zn}, \mathrm{Ni}, \mathrm{Hg}$, Sn são mais abundantes;

- Determinar a variação espacial das concentrações destes elementos nos sedimentos superficiais;

-Identificar as fontes dos elementos metálicos potencialmente contaminantes;

- Gerar subsídios para um futuro plano de gerenciamento da região. 


\section{CARACTERIZAÇÃO DA ÁREA DE ESTUDO}

\subsection{Localização}

O Complexo Estuarino da Baía de Paranaguá, situado na costa sul do Brasil, entre $25^{\circ} 16^{\prime}$ e $25^{\circ} 34^{\prime} \mathrm{S}$ e $48^{\circ} 17^{\prime}$ e $48^{\circ} 42^{\prime}$ W, é formado pelas baías de Paranaguá propriamente dita, incluindo a baía de Antonina, e das Laranjeiras (Figura 1), e apresenta área total de $612 \mathrm{Km}^{2}$ (LANA et al., 2000). As baías de Paranaguá e de Antonina localizam-se no eixo leste-oeste do complexo estuarino, que recebe a drenagem dos rios Cachoeira, Faisqueira, Nhundiaquara e o Guaraguaçu. A conexão do Complexo Estuarino da baía de Paranaguá com o Oceano Atlântico ocorre através de três canais principais, um canal menor e um canal artificial. ODRESKI (2002) estabeleceu o limite entre as baías de Paranaguá e Antonina no estreitamento definido entre a llha da Ponta Grossa e a llha do Teixeira (Figura 1).

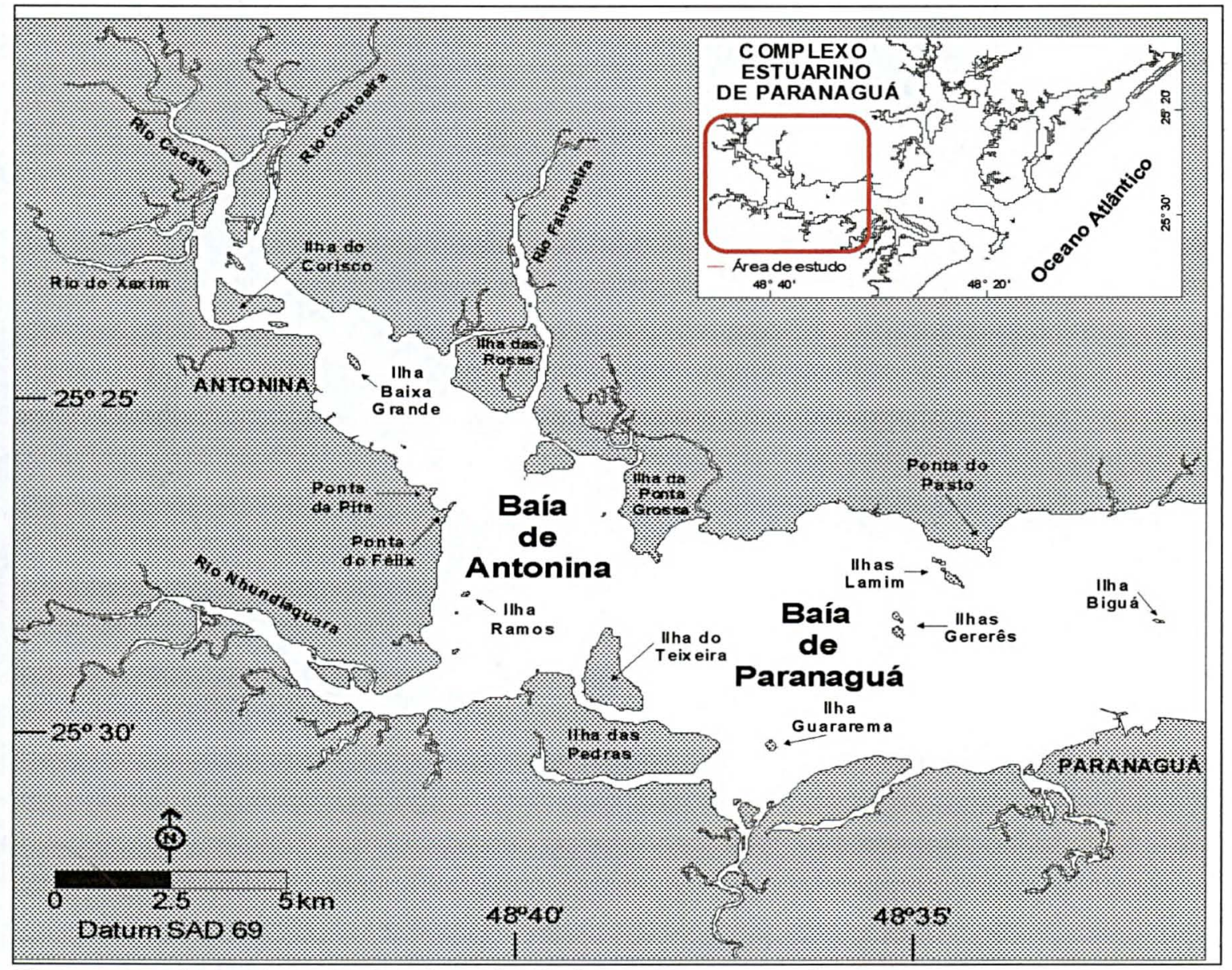

Figura 1 - Complexo Estuarino da Baía de Paranaguá. 


\subsection{Geologia regional e evolução da planície costeira}

O limite litorâneo do Paraná são as abruptas escarpas da Serra do Mar, que o separam do Primeiro Planalto Paranaense. A composição granítica, de rochas efusivas e sedimentares da Formação Guaratubinha (ANGULO, 1992) destas áreas é bastante resistente ao intemperismo.

A planície costeira paranaense possui cerca de $55 \mathrm{Km}$ na sua porção mais larga, na latitude de Paranaguá. Seu comprimento é de aproximadamente $90 \mathrm{Km}$, tendo como limite sul o sistema estuarino do Rio Saí-Guaçú, e norte o sistema estuarino do Mar de Ararapira (ANGULO, 1992).

ANGULO (1992) descreve a planície costeira como sendo composta por sedimentos procedentes de duas origens: continental e marinha. Os sedimentos continentais são associados às encostas, tais como leques, tálus e colúvios, sendo compostos por cascalhos sustentados por matriz arenoargilosa, e subordinadamente, sedimentos fluviais de rios entrelaçados. Nos sedimentos marinhos predominam areias quartzosas finas a muito finas, bem selecionadas e depositadas em feixes de cordões litorâneos paralelos à direção de praia atual (SW - NE).

LESSA et al (2000) interpretaram a planície costeira como sendo dois sistemas de laguna - ilha barreira, que evoluíram após as duas últimas transgressões (Transgressão Cananéia em 120.000 A.P. e Transgressão Santos em 5.100 A.P.), correspondentes ao último período interglacial e ao pós-glacial do Quaternário.

\subsection{Clima e Características hidrológicas}

A maioria das informações da circulação do complexo estuarino concentra-se no eixo leste-oeste correspondente às baías de Paranaguá e Antonina. Este eixo é regido por correntes de maré, com influência sazonal do aporte fluvial (KNOPPERS et al., 1987). Outros fatores que exercem influência na circulação são a geometria do corpo estuarino, a salinidade e a circulação da região costeira adjacente (KJERFVE, 1990; MIRANDA, 1996).

O clima regional é subtropical úmido mesotérmico, com duas estações bem definidas: a chuvosa no verão e a seca no inverno (Bigarella et al., 1978). O período chuvoso inicia no final da primavera e dura a maior parte do verão (fevereiro ocorre maior precipitação), enquanto que o período seco 
começa no final de outono permanecendo até o final do inverno (julho e agosto), interrompido, as vezes, por pequenos e fracos períodos chuvosos no início do inverno.

A porção leste, mais externa do Complexo Estuarino da Baía de Paranaguá, é dominada por águas da plataforma continental adjacente, enquanto que a porção oeste tem maior influência fluvial. O maior aporte de rios está localizado na margem sul e nos setores internos da baía. A descarga média anual de água doce é de $150 \mathrm{~m}^{3} / \mathrm{s}$, alcançando valores mais elevados no período de intensa precipitação (fevereiro).

MARONE \& JAMIYANAA (1997) classificam a maré do Complexo Estuarino da Baía de Paranaguá como micromaré, predominantemente semidiurna com desigualdades diurnas, sendo a amplitude média de 1,4 $\mathrm{m}$ em situação de quadratura e 1,7 $\mathrm{m}$ em períodos de sizígia. KNOPPERS et al. (1987) interpretaram que o eixo L - O do Complexo Estuarino da Baía de Paranaguá pode ser classificado como um estuário parcialmente misturado tipo 2, no diagrama Estratificação - Circulação de HANSEN \& RATTRAY (1965).

Segundo NOERNBERG (2001), o eixo L - O sofre maior influência do aporte de água doce de sua bacia de drenagem em relação ao eixo $\mathrm{N}-\mathrm{S}$, apresentando resposta mais rápida e intensa aos processos relacionados à estratificação da coluna d'água, intrusão salina, aporte de sedimentos fluviais e formação da zona de máxima turbidez. Este autor delimitou a presença de uma zona de máxima turbidez (ZMT) no eixo $L-O$, ocorrendo entre as llhas Gererês e o Porto de Paranaguá, relacionando a ocorrência desta zona com a geometria do corpo estuarino (Figura 1), intensidade das correntes de maré e estratificação da coluna d'água.

Outra característica hidrológica importante é o tempo de residência da água, que é de 3,49 dias para o Complexo Estuarino da Baía de Paranaguá.

\subsection{Distribuição dos sedimentos de fundo da Baía de Paranaguá}

BIGARELLA et al. $(1970 ; 1978)$ dividiu em três categorias fundamentais a composição do material de fundo da baía de Paranaguá. Na primeira encontra-se o material procedente do retrabalhamento direto da planície costeira, constituído principalmente por areia fina. A segunda categoria 
engloba o material de origem flúvio-continental, composta por cascalho, areia, silte e argila. $\mathrm{Na}$ terceira categoria encontra-se o material biogênico proveniente do interior do sistema estuarino, como as frações de matéria orgânica e de carbonato. BIGARELLA et al. (1978) indicam que, a jusante da cidade de Paranaguá, a classe modal predominante está na fração fina a muito fina, bem selecionada, sendo que o diâmetro médio e o grau de seleção tendem a diminuir em direção ao interior do estuário e que as frações mais grossas ocorrem preferencialmente associados aos canais de maré, enquanto que o material mais fino está depositado nos locais de menor energia. Isto indica que a distribuição dos sedimentos de fundo é controlada pelo ambiente físico, principalmente pela profundidade e pelas correntes de maré.

O projeto "Estudos Ambientais em Áreas Costeiras Oceânicas no Sul do Brasil" (PETROBRÁS, 1997) realizou novos levantamentos dos sedimentos de fundo na baía de Paranaguá, os quais apresentaram algumas variações em relação aos estudos anteriores. SOARES et al. (1997) e APPA (Administração dos Portos de Paranaguá e Antonina) (1997) compararam os resultados obtidos por BIGARELLA et al. $(1970 ; 1978)$ e pela PETROBRÁS (1997) e observaram importantes mudanças na distribuição dos sedimentos de fundo das baías de Paranguá e Antonina, onde na porção oeste ocorreu um aumento da porcentagem dos sedimentos arenosos.

SOARES et al. (1996) compartimentaram o eixo L - O do Complexo Estuarino da Baía de Paranaguá em três setores principais: i) uma porção superior, à montante do estuário (baía de Antonina) com grande influência fluvial, composta por sedimentos heterogêneos, sendo a porcentagem de finos superior às demais porções do estuário; ii) porção intermediária com influência fluvial e marinha, porém com menor influência de finos; iii) uma porção composta por areia fina a muito fina, delimitada pela área de influência da desembocadura, onde ocorre efetiva ação marinha.

ODRESKI (2002) indica que ocorreram grandes mudanças na composição dos sedimentos da baía de Antonina e na porção ocidental da baía de Paranaguá entre 1966 e 1995, onde praticamente toda a área estudada é caracterizada por aumento do diâmetro médio e melhoria do grau de seleção dos sedimentos de fundo no período entre os levantamentos comparados. Este autor ressalta que as mudanças mais significativas foram 
observadas na região da Ponta da Graciosa (Figura 1), nas margens da baía de Antonina e na margem sul da porção ocidental da baía de Paranaguá.

\subsection{Aspectos industriais e de impactos ambientais}

Na região do Complexo Estuarino da Baía de Paranaguá coexistem atividades urbanas, portuárias, industriais (fertilizantes, estocagem de produtos químicos, granéis), dragagens, atividades pesqueiras, entre muitas outras.

A cidade de Paranaguá tem sua área urbana cercada ao norte pela baía, ao oeste pelo rio Emboguaçu e ao leste pelo rio Itiberê (Figuras 1 e 2).

No levantamento realizado por LAUTERT (1999) muitos impactos, tais como desmatamento, ocupação desordenada, emissão de esgoto doméstico e industrial, aterros e resíduos sólidos, foram observados nessas regiões limites da cidade. Ao sul encontra-se uma área de expansão, com crescente taxa de urbanização sem planejamento e infra-estrutura, como saneamento básico e água encanada. Segundo os moradores da Vila Esperança, os terrenos foram invadidos após as eleições de 1998, além de terem sido uma promessa política.

A oeste, as margens do Rio Emboguaçu, encontra-se a Vila Guarani, onde aterros cobrem toda a vegetação de mangue. As marés de lua cheia, geralmente invadem casas e comércios trazendo contaminação causada pela poluição hídrica. Na maré baixa o lodo contaminado expõe a população ribeirinha ao mau cheiro e à sujeira por resíduos sólidos (LAUTERT, 1999).

Já na área das nascentes do Rio Emboguaçu encontram-se dois outros tipos de impactos: na chamada colônia de Santa Rita encontra-se um lixão sem convenção sanitária legal e as lavras de areia (LAUTERT, 1999).

LAUTERT (1999) cita que a questão do desenvolvimento e pobreza se encaixa na cidade de Paranaguá, onde ao mesmo tempo que se aumenta o produto interno bruto do município, decresce a qualidade de vida e emerge a pobreza.

Sabe-se que a região onde localiza-se o município de Antonina não possui uma área industrial, tendo o porto como local de escoamento de mercadorias. Porém, existem atividades agrícolas ao redor do município onde ocorre utililização de agrotóxicos, que podem ter um potencial poluidor. 
MANTOVANELLI (1999) realizou um estudo sobre a circulação na seção transversal em frente ao porto de Paranaguá, verificando, através da média das velocidades das correntes, que o fluxo predominante ocorre em direção à margem norte na vazante e em direção à margem sul na enchente. Portanto, o acúmulo de matéria orgânica e sedimentos finos na margem norte da baía de Paranaguá provavelmente está condicionado à esta forçante. Os sedimentos estuarinos das zonas profundas dos canais caracterizam-se, em geral, por apresentarem baixas concentrações de matéria orgânica.

A distribuição da matéria orgânica dos sedimentos superficiais no Complexo Estuarino de Paranaguá está condicionada à circulação local, principalmente na seção transversal em frente ao porto de Paranaguá. Em Antonina, a matéria orgânica acompanha a distribuição dos sedimentos finos, predominando argila.

\subsection{Aspectos tecnológicos da dragagem}

\subsubsection{Utilização das atividades de dragagem}

As obras de dragagem são essenciais para o desenvolvimento e a manutenção da navegação oceânica e fluvial, para o gerenciamento de outros usos, bem como para a recuperação de ambientes aquáticos. A remoção e disposição final dos sedimentos dragados representam uma parte importante em todo o gerenciamento hídrico. Logo, é necessário planejá-las e executá-las de acordo com as regras econômicas, sociais, ambientais e técnicas (KITZMANN, et al., 2002).

BRAY, et al. (1997) dividiram os processos de dragagem em dois grupos: i) a dragagem inicial, a qual retira o material virgem formando o canal artificial; e as dragagens de manutenção, para retirada do material sedimentar depositado recentemente; ii) a dragagem ambiental, a qual procura remover uma camada superficial de sedimento contaminado sem que haja a ressuspensão destes contaminantes.

A decisão sobre as alternativas de disposição ou reutilização do material dragado deve levar em conta, além dos aspectos econômicos, os impactos ambientais. O número de alternativas ficará reduzido para a disposição de um material dragado contaminado, tendo em vista as restrições ambientais impostas. Normalmente ocorrem três possibilidades para a disposição do 
material dragado: uso benéfico, disposição em corpos hídricos e disposição em terra (KITZMANN et al., 2002).

\subsubsection{Tipos de dragas}

A escolha da draga a ser utilizada é fundamental para definir o nivel de impacto ambiental causado pelas obras de dragagem e deve ser realizada em função do tipo de sedimento a ser dragado. Existem três tipos básicos de dragas, referindo-se ao modo de escavação e operações mecânicas, hidráulicas e hidráulico-mecânicas (KITZMANN, 2002).

- Dragas mecânicas - empregam meios mecânicos para as escavações, sendo geralmente similares aos equipamentos utilizados no continente para a realização de escavações e aterros. Este tipo de draga é muito empregado quando há necessidade de remover pontos localizados, sem perturbar áreas maiores.

- Draga hidráulico - mecânica - o tipo "trailing hopper" é o mais empregado no Brasil. O material é hidraulicamente transportado por meio de uma linha de sucção como uma mistura de sedimento e água, através de uma bomba centrífuga e retido em uma cisterna para ser descartado.

- Dragas hidráulicas - são de tecnologia mais moderna, que empregam o bombeamento centrífugo da água como forma de escavação subaquática. Às vezes estas dragas podem conduzir o material dragado até o local de despejo, ou usar sistema de barcaças auxiliares.

\subsection{Dragagens no Complexo Estuarino de Paranaguá}

As áreas sujeitas a dragagens periódicas localizadas no interior do complexo estuarino são as regiões onde se efetuam dragagens de manutenção para a profundidade de controle dos canais de navegação. Um dos maiores problemas ambientais atuais do Porto de Paranaguá é a escolha de um sítio de despejo adequado para o material dragado nos berços de atracação localizados na Bacia de Evolução. 


\subsubsection{Características técnicas do Porto de Paranaguá}

O Cais Comercial do Porto de Paranaguá (Figura 2) tem uma extensão de 2.616 metros com faixa acostável de 13 berços com calados diferenciados de acordo com a estrutura física de cada berço, podendo chegar a profundidade de 13 metros. Permite a atracação simultânea de 12 a 14 navios desde os pequenos de cabotagem até os supergraneleiros de 270 metros de comprimento.

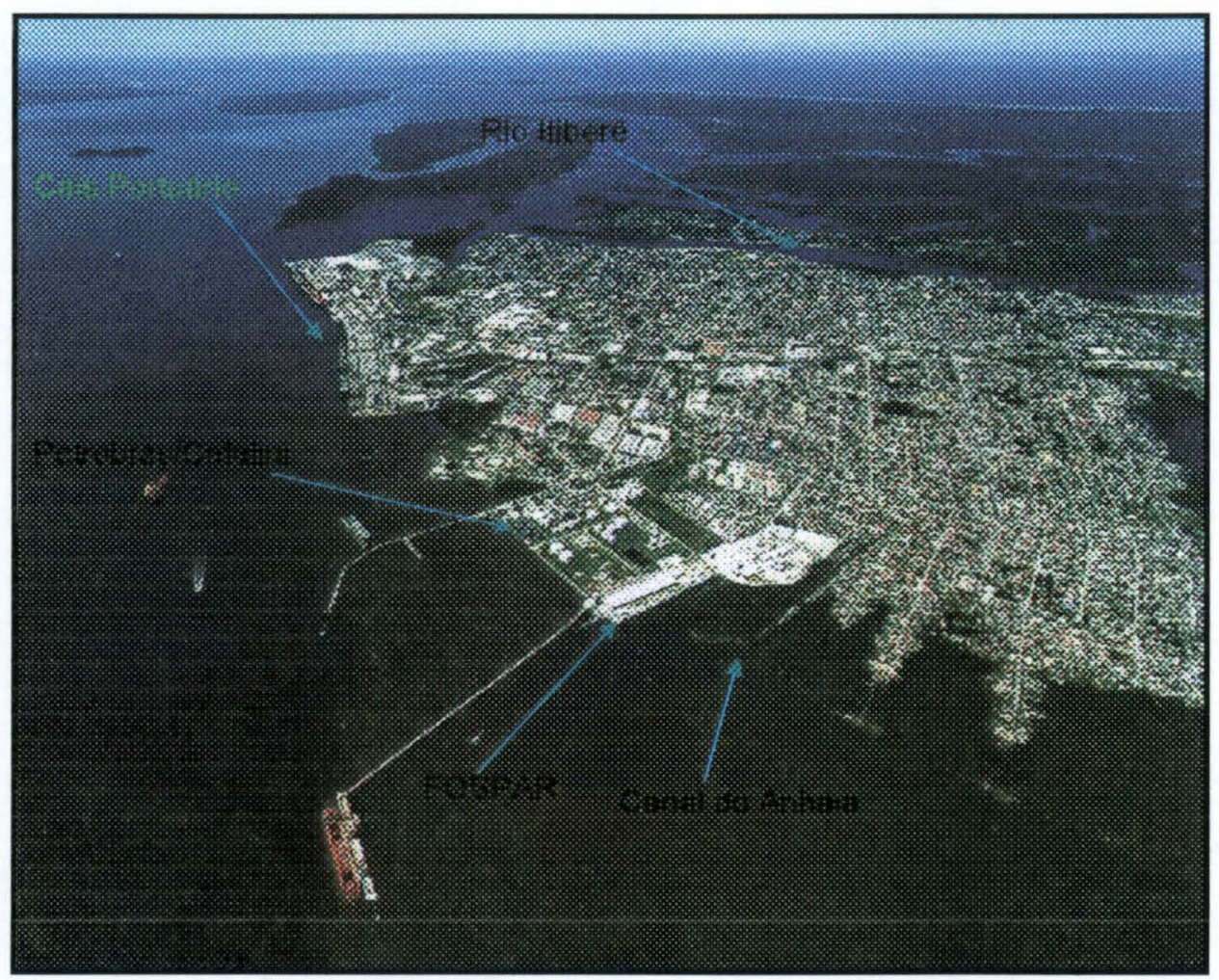

Figura 2 - Vista aérea do município de Paranaguá.

Vazamento de aproximadamente 400.000 litros de nafta (18/10/2001) e o acidente no poliduto OLAPA (Oleoduto Araucária-Paranaguá) (16/02/2001) - com vazamento de 50.000 litros de diesel foram alguns dos acidentes recentes ocorridos que tiveram influência no Complexo Estuarino de Paranaguá.

\subsubsection{Características técnicas do Porto de Antonina}

O terminal Barão de Teffé, de domínio público da APPA, é composto pelo cais comercial (para navios de até $155 \mathrm{~m}$ ), com calado de 19 pés $(5,79$ 
$\mathrm{m}$ ), por dois armazéns (2.436 m e $1.056 \mathrm{~m}$ de comprimento), e mais balança (100 t), para operação de múltiplo uso em área de $256.623 \mathrm{~m}^{2}$.

Em 1999, a Interportos e a APPA firmaram acordo operacional que possibilitou a movimentação de granéis sólidos (fertilizantes, sal, trigo) pelo sistema de transbordo de navios ao largo.

O Terminal Portuário da Ponta do Félix, privatizado pela APPA, através de arrendamento de $72.000 \mathrm{~m}^{2}$, possui cais com $360 \mathrm{~m}$ de extensão que permite atracação de 2 navios simultaneamente.

Para aumentar, pela primeira vez, a profundidade do canal de acesso entre Paranaguá e Antonina de 8 para 10 metros foram dragados aproximadamente 5 milhões de $\mathrm{m}^{3}$ de sedimentos (KITZMANN, 2002). Como não havia condições de despejar o material dragado no continente, por questões técnicas e ambientais, bem como de levar os sedimentos até a área circular externa (sítio de despejo na plataforma), por questão de ordem econômica, a solução encontrada e autorizada pelos órgãos ambientais foi colocar este material ao lado e ao longo do canal de acesso a Antonina (KITZMANN, 2002).

\subsection{Poluição dos sedimentos}

Os estudos anteriores efetuados até o momento abordaram os aspectos ambientais relacionados com a contaminação por elementos traços metálicos, dessa região, através do estudo dos sedimentos de fundo.

Com base em dados anteriores existentes, este texto aponta as condições ambientais, as áreas potencialmente mais impactadas por metais pesados e suas principais fontes contaminantes no complexo estuarino da Baía de Paranaguá.

O estudo para levantamentos ambientais pré e pós-dragagem do Canal da Galheta e bacia de evolução efetuados pela administração dos portos de Paranaguá e Antonina - 1998/1999 (APPA), realizou análises de elementos metálicos, de óleos, graxas e organoclorados em sedimentos superficiais e em testemunhos de $50 \mathrm{~cm}$. (tabela 1) 
Tabela 1: Qualidade do sedimento de fundo na área de influência das atividades do Porto de Paranaguá, com base nos critérios reportados por "Australian Environment Protection Authority" (http://www.epa.nsw.gov.au) e os limites das concentrações de elementos-traços definidos pela legislação brasileira, valores entre parênteses, (SEMA, 1980); e as concentrações mínimas e máximas nas fase pré- e pós-dragagem são apresentadas em ppm (mg/kg).

\begin{tabular}{|c|c|c|c|c|}
\hline & & $\begin{array}{c}\text { PRE-DRAGAGEM. } \\
\text { (MAIO/98) }\end{array}$ & $\begin{array}{l}\text { PÓS-DRAGAGEM. } \\
\text { (MARÇO/99) }\end{array}$ & $\begin{array}{l}\text { LIMITES } \\
\text { CRÏTICOS }\end{array}$ \\
\hline & Arsênio & $<0,1-3,22$ & $0,33-3,17$ & $5-40$ \\
\hline & Cádmio & $<0,5-0,9$ & $<2,5$ & $1,2-9,6(5)$ \\
\hline & Chumbo & $<5-18,07$ & $<25-43,43$ & $40-218(20)$ \\
\hline & Cobre & $<2,5-6,58$ & $<2,5-5,35$ & $34-270(10)$ \\
\hline \multirow[t]{4}{*}{ METAIS } & Cromo & $<5-28,22$ & $<5-12,45$ & 81 - $370(25)$ \\
\hline & Níquel & $<5-11,4$ & $<2,5-10,34$ & $2-21$ \\
\hline & Zinco & $0,7-43,04$ & $3,73-32,88$ & $150-410(20)$ \\
\hline & Mercúrio & $<0,04$ & $<0,1$ & $0,15-0,71(0,1)$ \\
\hline \multicolumn{2}{|c|}{ ÓLEOS E GRAXAS } & $18,23-1185,3$ & não analisado & $300-1500$ \\
\hline & Clordane & & não analisado & $0,0025-0,03$ \\
\hline ORGANO- & Dieldrin & $<0,0001$ & não analisado & $0,00002-0,008$ \\
\hline \multirow[t]{2}{*}{ CLORADOS } & DDT & & não analisado & $0,0016-0,046$ \\
\hline & PCB & & não analisado & $0,023-0,18$ \\
\hline
\end{tabular}

Os resultados mostraram que entre os elementos metálicos investigados, o zinco, o cromo e o chumbo apresentaram valores acima dos limites permitidos. Verificou-se que as maiores concentrações desses elementos e compostos ocorreram nas estações situadas na bacia de evolução do Porto de Paranaguá e/ou muito próximas, sugerindo que a fonte destes compostos está associada diretamente às atividades portuárias. Os resultados obtidos a partir dos testemunhos não apresentaram o padrão esperado, de concentrações mais elevadas em camadas superiores. A ocorrência de concentrações maiores nas camadas inferiores, em relação às superiores, impossibilitaram a determinação dos níveis de referências ou background desses elementos analisados.

Em estudo realizado nas fases de dragagem do canal do Porto de Paranaguá, em 1998 e 1999, nota-se as concentrações de alguns elementos 
metálicos e de óleos e graxas na região do atual empreendimento. Estes valores estão relacionados na tabela 2 .

Tabela 2: Qualidade do sedimento na área de influência do Porto de Paranaguá, limites das concentrações de elementos-traços definidos pela legislação brasileira, valores entre parênteses, (SEMA, 1980); as concentrações máximas e mínimas nas campanhas de 1998 e 1999 são apresentadas em ppm (mg/Kg).

\begin{tabular}{ccc}
\hline Metais & Valores máximos e mínimos (1999) & Limites críticos \\
\hline Arsênio & $<0,1-3,17$ & $5-40$ \\
Cádmio & $<0,5-2,5$ & $1,2-9,6$ \\
Chumbo & $<5-43,43$ & $40-218$ \\
Cobre & $<2,5-6,58$ & $34-270$ \\
Cromo & $<5-28,22$ & $81-370$ \\
Níquel & $<2,5-11,4$ & $2-21$ \\
Zinco & $0,7-43,04$ & $150-410$ \\
Mercúrio & $<0,04-<0,1$ & $0,15-0,71$ \\
Óleos e graxas & $18,23-1185,3$ & $300-1500$ \\
\hline
\end{tabular}

Em APPA (1999) foram verificadas as maiores concentrações dos elementos e compostos investigados em locais situados na bacia de evolução do Porto de Paranaguá elou muito próximas.

Entre os elementos traços investigados, apenas o zinco, o cromo e o chumbo apresentaram concentrações que excedem os limites permitidos pela legislação brasileira. Porém, o arsênio, cádmio, cobre e o níquel ocorreram em concentrações relativamente elevadas, aproximando-se dos limites máximos permitidos. Todos estes elementos podem ser bastante tóxicos para a biota e tendem a se acumular ao longo da cadeia alimentar.

A tabela 3 mostra os resultados obtidos em um levantamento realizado no porto da cidade de Rio Grande comparando os elementos metálicos com suas fontes potenciais. Estes resultados podem ser comparados com o porto de Paranaguá, pois em ambas as áreas coexistem atividades industriais e portuárias semelhantes. 
Tabela 3. Fontes de enriquecimento para metais pesados presentes no estuário da Lagoa dos Patos - RS. Modificado de Baisch (1997).

\begin{tabular}{cccccccc}
\hline Fontes & $\mathrm{Pb}$ & $\mathrm{Cu}$ & $\mathrm{Zn}$ & $\mathrm{Cd}$ & $\mathrm{Cr}$ & $\mathrm{Ni}$ \\
\hline Emissário cloacal & $\mathrm{X}$ & $\mathrm{X}$ & $\mathrm{X}$ & $\mathrm{X}$ & & \\
Indústrias de fertilizantes & $\mathrm{X}$ & & & $\mathrm{X}$ & & \\
Indústria geral & & & & & & \\
& & $\mathrm{X}$ & $\mathrm{X}$ & & & \\
Equipamentos portuários e sucatas & & & & & & $\mathrm{X}$ & \\
Atividade portuária & & & & & & & \\
\end{tabular}

\subsection{Processos de ressuspensão}

Os trabalhos de dragagens em portos, rios e canais de navegação, promovem ressuspensão de sedimentos, podendo acarretar a liberação de contaminantes, que pode se tornar crítico dependendo do nível de poluição dos sedimentos de fundo (DELAUNE \& SMITH, 1985; THOMAS, 1987). Apesar dos sedimentos influenciarem diretamente a qualidade da água, não existem normas de qualidade dos sedimentos, como aquelas existentes para as águas estabelecidas pelo CONAMA (1986). Assim sendo, com vistas a caracterização do impacto ambiental, os valores limites de muitos parâmetros, tais como os metais pesados, devem ser estabelecidos especificamente para a região estudada.

A cidade de Paranaguá possui sua economia voltada para o mar e é responsável pela existência de vários pontos de descarga de efluentes sem tratamento, principalmente de natureza doméstica e industrial. Devido à presença do porto de Paranaguá, o estuário apresenta, ainda, constantes trabalhos de dragagem necessários para a manutenção do canal de navegação. Sabe-se que quanto mais profundo o metal pesado encontra-se na camada sedimentar, menor será sua capacidade de troca com a água. Porém, esta relação pode ser modificada por processos de ressuspensão. Como dito anteriormente, a remobilização do sedimento pode provocar mudanças em algumas condições geoquímicas (como pH e Eh) e ocasionar 
liberação dos elementos metálicos para a água, tendo como consequência, sua contaminação. Essas perturbações do sedimento podem ocorrer por diversos fatores, tanto naturais como ondulações e movimentos turbulentos, quanto antrópicos como tráfego de navios e trabalhos de dragagens (BAISCH, 1994). 


\section{Materiais e métodos}

\subsection{Método de Execução}

O presente estudo foi realizado em três etapas complementares descritas a seguir:

\section{Etapa 1 - Avaliação dos impactos das dragagens na área compreendida} entre a Baía de Antonina e o Porto de Paranaguá) - Antes (05/2001) e após (02/2002) a realização das dragagens foram coletadas amostras de sedimentos superficiais, em 9 pontos, dispostos em 3 seções ao longo dos $12 \mathrm{Km}$ compreendidos entre a Ponta do Félix e o terminal da Petrobrás (Figura 3). A primeira seção, estações 1,4 e 7 , refere-se ao local de despejo do material dragado. No local de dragagem (canal de acesso do Porto de Antonina) encontra-se a segunda seção, estações 2, 5 e 8. Na terceira seção, estações 3 , 6 e 9 , encontra-se o local que poderia ser afetado pela atividade de dragagem. As amostras de sedimentos foram conservadas congeladas até a realização das seguintes análises: elementos traços ( $\mathrm{Al}, \mathrm{As}, \mathrm{Cd}, \mathrm{Cr}, \mathrm{Cu}, \mathrm{Fe}, \mathrm{Mn}, \mathrm{Pb}, \mathrm{Zn}$, $\mathrm{Ni}, \mathrm{Hg}, \mathrm{Sn}$ ). Durante a realização das operações de dragagem, foram efetuadas três campanhas de amostragem em 3 pontos: um antes do início da pluma (em direção à região mais interna da baía); um no gradiente de turbidez dentro da pluma de sedimentos; um após a pluma (em direção à desembocadura da baía). Em cada ponto, foram coletados sedimentos superficiais para determinação de metais (enfocando principalmente as frações biodisponíveis dos mesmos), que tenham sido detectados na etapa de prédragagem. 


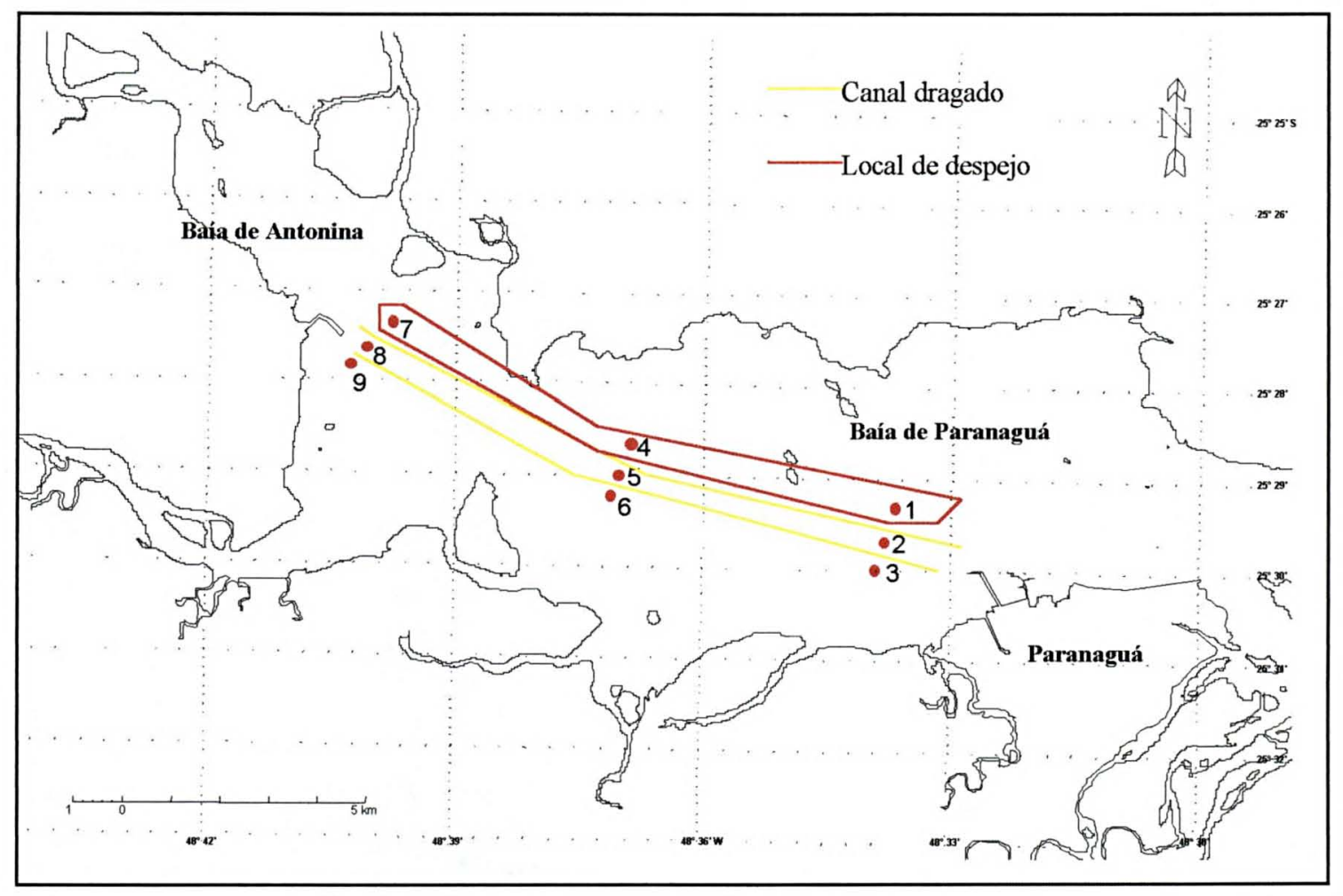

Figura 3 - Localização dos pontos de coleta de sedimento superficial da primeira etapa.

Etapa 2 - Avaliação e monitoramento da qualidade do sedimento nas imediações da indústria de fertilizantes FOSPAR - baía de Paranaguá: foram realizadas 4 campanhas, respectivamente em janeiro, maio, agosto e novembro de 2001, com 11 pontos distribuídos nas cercanias da industria de fertilizantes FOSPAR e em 1 ponto controle situado na Baía das Laranjeiras (Figura 4). Em cada amostra foram determinados os teores de arsênio (As) e metais cobre $(\mathrm{Cu})$, cádmio $(\mathrm{Cd})$, cromo $(\mathrm{Cr})$, mercúrio $(\mathrm{Hg})$, níquel $(\mathrm{Ni})$, chumbo $(\mathrm{Pb})$, zinco $(\mathrm{Zn})$ e carbono orgânico total. 


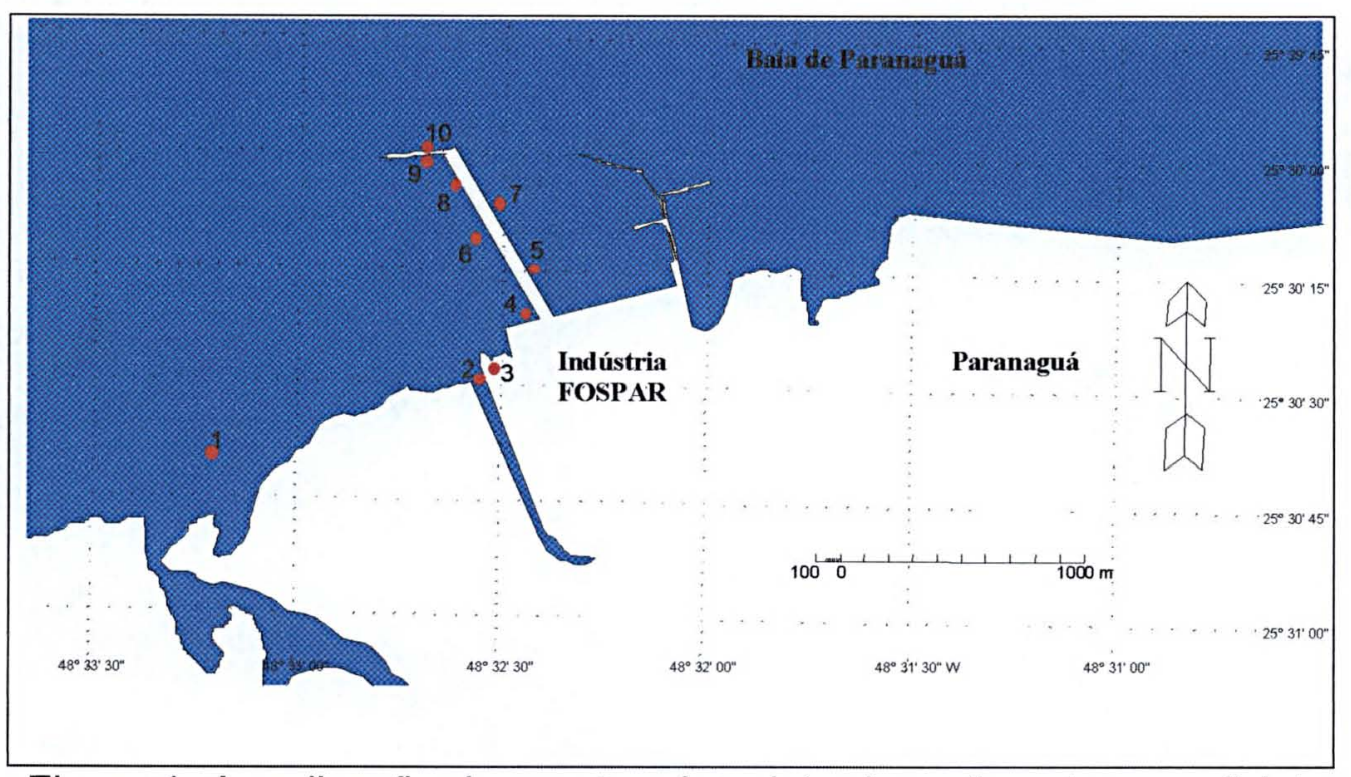

Figura 4 - Localização dos pontos de coleta de sedimento superficial da segunda etapa.

Etapa 3 - Avaliação da qualidade do sedimento na bacia de evolução do porto de Paranaguá: foram coletados (10/2002) 7 pontos (Figura 5) para análise dos elementos Arsênio (As), Cádmio (Cd), Cobre (Cu), Cromo ( $\mathrm{Cr}$ ), Chumbo $(\mathrm{Pb})$, Níquel (Ni) e Zinco $(\mathrm{Zn})$ para a caracterização da grau de contaminação dos sedimentos da região.

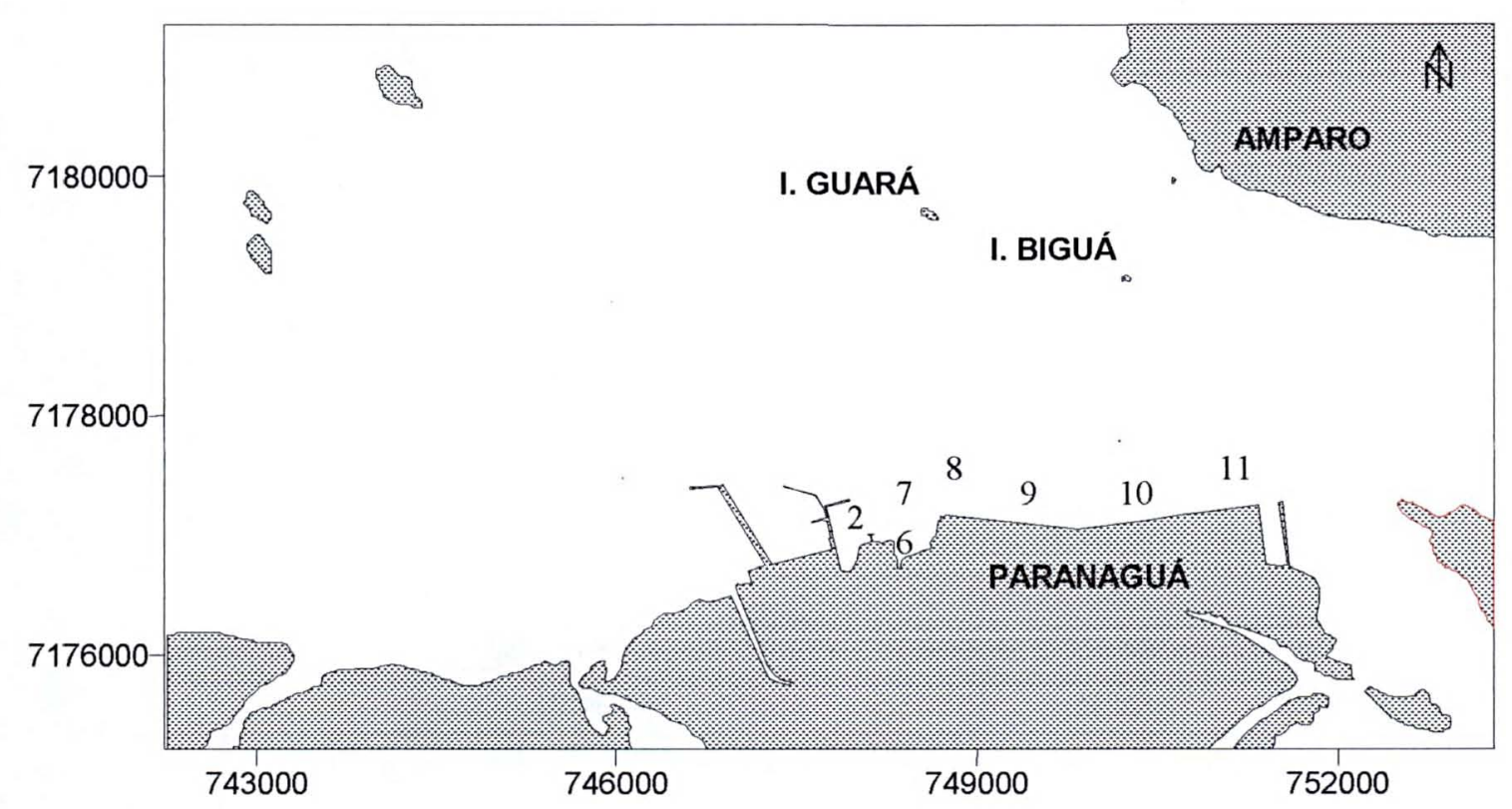

Figura 5 - Localização dos pontos de coleta de sedimento superficial da terceira etapa. 


\subsection{Instrumentação e Método de Análises de Laboratório}

Para o desenvolvimento e alcance dos objetivos propostos neste trabalho de pós-graduação foram disponiveis a infra-estrutura laboratorial e de logística de campo do Centro de Estudo do Mar e do Departamento de Geologia (Laboratório de Hidrogeologia). Foram utilizados:

- Equipamento de busca-fundo tipo Petit-Ponar para realização da amostragem de sedimentos de fundo;

- Equipamento DGPS capaz de georreferenciar dados gerados por outros equipamentos e cadastrar pontos com alta precisão;

- Embarcações de diferentes portes;

- Computadores e programas adequados ao processamento dos dados.

\section{Determinação do Carbono Orgânico Total}

Foi utilizado o método de Strikland \& Parsons (1972), adaptado para fim titrimétrico, que baseia-se na oxidação da matéria orgânica, determinado através de uma titulação com solução de sulfato ferroso amoniacal (Baumgarten et al., 1996).

\section{Análise de elementos metálicos}

Foram realizadas duas extrações de elementos metálicos, uma extração forte utilizando $\mathrm{HF} \mathrm{e} \mathrm{HNO}_{3}$ com aquecimento, e outra extração fraca com a utilização de $\mathrm{HCl}$ 0,1N. A extração forte trata de dissolver por completo toda a estrutura cristalina dos grãos presentes no sedimento, liberando os elementos metálicos tanto naturais quanto os resultantes das atividades antrópicas. Já a extração fraca tem como objetivo detectar os contaminantes fracamente ligados ao sedimento, provavelmente originados por atividade antrópica. Portanto, este tipo de extração será, neste trabalho, relacionada com a biodisponibilidade de tais contaminantes. A utilização de $\mathrm{HCl} 0,1 \mathrm{~N}$, sem aquecimento, na extração fraca representa apenas uma fração que pode estar disponível. É importante ressaltar que outras frações disponíveis podem ser detectadas com 0 uso de outros reagentes. As determinações dos metais foram realizadas pelo método de espectrofotometria de absorção atômica, disponível no Laboratório de Hidrogeologia (UFPR). Os elementos arsênio, 
níquel e mercúrio foram determinados pelo método de espectrofotometria de absorção atômica e vapor frio, respectivamente, nos Laboratórios de Oceanografia Geológica e de Hidroquímica da Fundação Universidade Federal do Rio Grande.

\subsection{Tratamento Estatístico}

Para realizar a análise estatística dos dados obtidos foram utilizadas as seguintes metodologias: análises de teste " $\mathrm{t}$ "; análise multivariadas de agrupamento (Cluster Analysis) e análise de ordenação pelo escalonamento multidimensional (MDS).

A análise de ordenação permite gerar um arranjo de objetos em um espaço dimensional, como num "mapa", sendo uma representação gráfica da similaridade (ou distância) entre os objetos, neste caso as estações.

A análise de agrupamento (Cluster Analyisis) possibilita gerar grupos de amostras similares entre diversos objetos. O resultado é mostrado em um diagrama de árvore chamado dendograma, com as amostras plotadas no eixo $x e$ as respectivas similaridades dos grupos no eixo $y$. 


\section{Resultados}

Os resultados são descritos, respectivamente, a cada etapa complementar do trabalho. O limite crítico adotado neste estudo são da Legislação Canadense (Canadian Sediment Quality Guidelines), os quais foram adotados por serem bastante conservativos e asseguram com alto grau de confiança que se as concentrações encontradas no ambiente forem iguais ou inferiores a este valor.

\subsection{Primeira etapa: Avaliação dos impactos das dragagens na área compreendida entre a Baía de Antonina e o Porto de Paranaguá}

Os resultados da seleção, utilizando as estações 5 e 6 , dos elementos químicos a serem analisados na primeira etapa são apresentados na tabela $4 \mathrm{e}$ figuras 5 a 11, e comentados a seguir. Foram utilizadas estas duas estações ( 5 e 6) por estarem localizadas, respectivamente, no canal dragado e no local de possivel influência da atividade de dragagem. Nesta seleção dos elementos foi utilizada apenas a extração forte. Através desta fase de seleção, com uma gama maior de elementos (onze), pode-se obter quais destes que apresentaram concentrações significativas, ou seja, acima ou próxima do limite crítico adotado. Estes elementos selecionados foram analisados nas demais estações.

Tabela 4. Concentrações dos elementos traços nos sedimentos superficiais dos pontos 5 e 6 nas fases de pré e pós-dragagem. As concentrações são expressas em ppm $(\mathrm{mg} / \mathrm{Kg})$. Os elementos selecionados estão em negrito e assinalados na última linha da tabela.

\begin{tabular}{cccccccccccc}
\hline Estação & $\mathbf{F e}$ & $\mathbf{A l}$ & $\mathbf{C d}$ & $\mathbf{P b}$ & $\mathbf{C r}$ & $\mathbf{C u}$ & $\mathbf{Z n}$ & $\mathbf{H g}$ & $\mathbf{A s}$ & $\mathbf{N i}$ & $\mathbf{S n}$ \\
\hline 5 pré & $1.810,9$ & 17,4 & 1,9 & 18,6 & 27,3 & 4,4 & 52,2 & 0,09 & 18,7 & 7,9 & 2,1 \\
6 pré & $1.540,9$ & 14,9 & 2,4 & 25,4 & 48,2 & 15,7 & 69,9 & 0,09 & 27,1 & 12,2 & 2,1 \\
5 pós & $1.578,9$ & 1,4 & 1,9 & 24,8 & 65,7 & 13,9 & 61,5 & 0,27 & 19,9 & 19,3 & 2,3 \\
6 pós & $1.810,9$ & 11,6 & 1,7 & 19,6 & 36,5 & 4,7 & 46,5 & $<0,5$ & 31,2 & 8,5 & 0,7 \\
Seleção & Não & Não & Sim & Sim & Sim & Sim & Não & Sim & Sim & Sim & Não
\end{tabular}

\subsubsection{Arsênio}

Todas as amostras (exceto a coletada no ponto P2, na campanha Pluma 1) apresentaram concentrações totais de arsênio acima do limite crítico 
estabelecido, de 7,24 ppm (Figura 6), indicando que este elemento constitui um contaminante importante para a área investigada. Porém, não foram verificadas diferenças significativas nas concentrações totais de arsênio entre as campanhas de Pré-dragagem, Pluma 1 e Pós-dragagem.

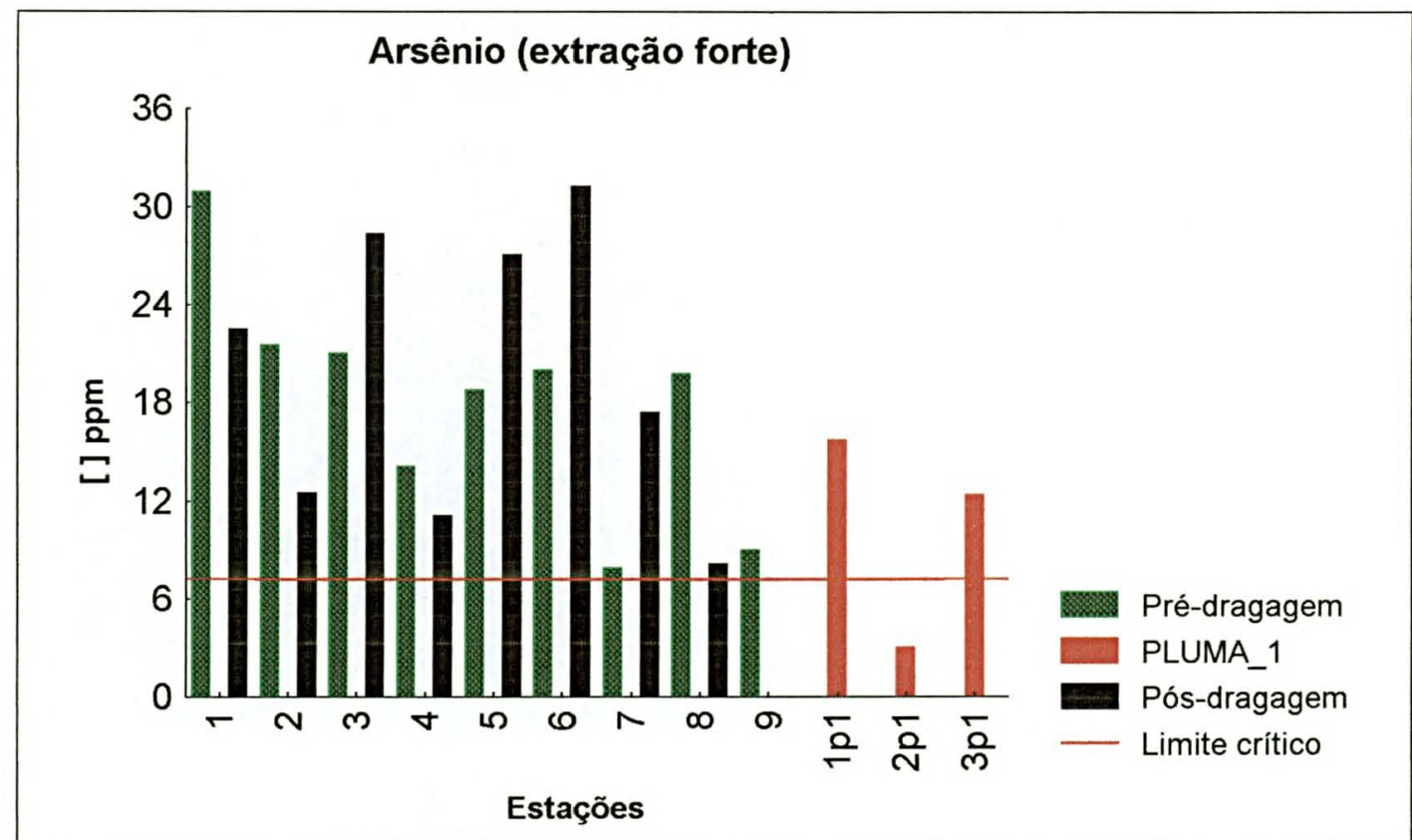

Figura 6 - Concentrações de arsênio (ppm) obtidos através de extração total (forte) em amostras de sedimento superficial das estações investigadas nas campanhas Pré-dragagem, Pluma 1 e Pós-Dragagem. A linha horizontal (em vermelho) representa o limite crítico específico $(7,24 \mathrm{ppm})$ para este metal adotado na avaliação do grau de contaminação dos sedimentos.

\subsubsection{Níquel}

A análise estatística efetuada (teste $t$ ) não detectou diferenças significativas das concentrações totais de níquel nas três fases investigadas, Pré-dragagem, Pluma 1 e Pós-dragagem, sugerindo que as atividades de dragagem não afetaram a qualidade dos sedimentos em relação a este metal (Figura 7).

Entretanto, as concentrações totais de níquel registrado na maior parte das amostras de sedimentos superficiais ultrapassaram o limite crítico adotado, de $15,9 \mathrm{ppm}$. A exposição dos organismos aquáticos a sedimentos contaminados por níquel, pode resultar em uma variedade de efeitos adversos (CCREM, 1987). Portanto, este metal pode representar um contaminante potencialmente importante para o ecossistema em questão. 


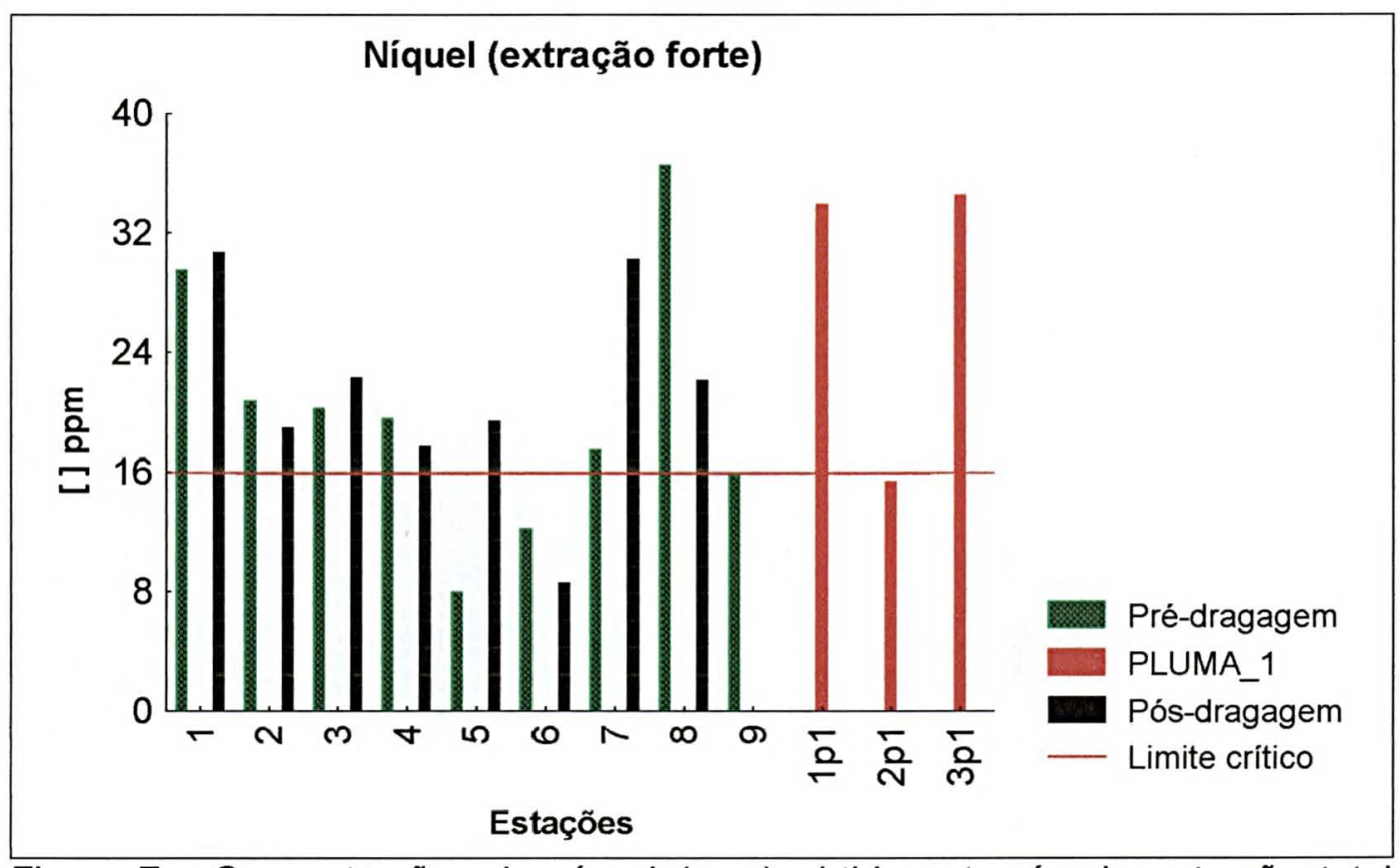

Figura 7 - Concentrações de níquel (ppm) obtidos através de extração total (forte) em amostras de sedimento superficial das estações investigadas nas campanhas Pré-dragagem e Pós-Dragagem, bem como na campanhas Plumas 1. A linha horizontal (em vermelho) representa o limite crítico específico (15,9 ppm) para este metal adotado na avaliação do grau de contaminação dos sedimentos.

\subsubsection{Mercúrio}

Verificou-se que as concentrações totais de mercúrio sofreram uma diminuição na Pluma 1 em relação às campanhas de Pré e Pós-dragagem (Figura 8 ), onde as concentrações excederam o limite crítico adotado, de 0,13 ppm. Entretanto, não foram verificadas diferenças significativas nas concentrações deste elemento entre as campanhas de Pré e Pós-dragagem.

Como o mercúrio é altamente tóxico para a biota, especialmente na forma de metil-mercúrio, e tem o potencial de acumular em altos níveis nos organismos aquáticos (CCREM, 1987), torna-se imprescindivel a determinação dos teores deste metal na coluna d'água durante as operações de dragagem, para verificar se houve um aumento na disponibilidade para a biota. 


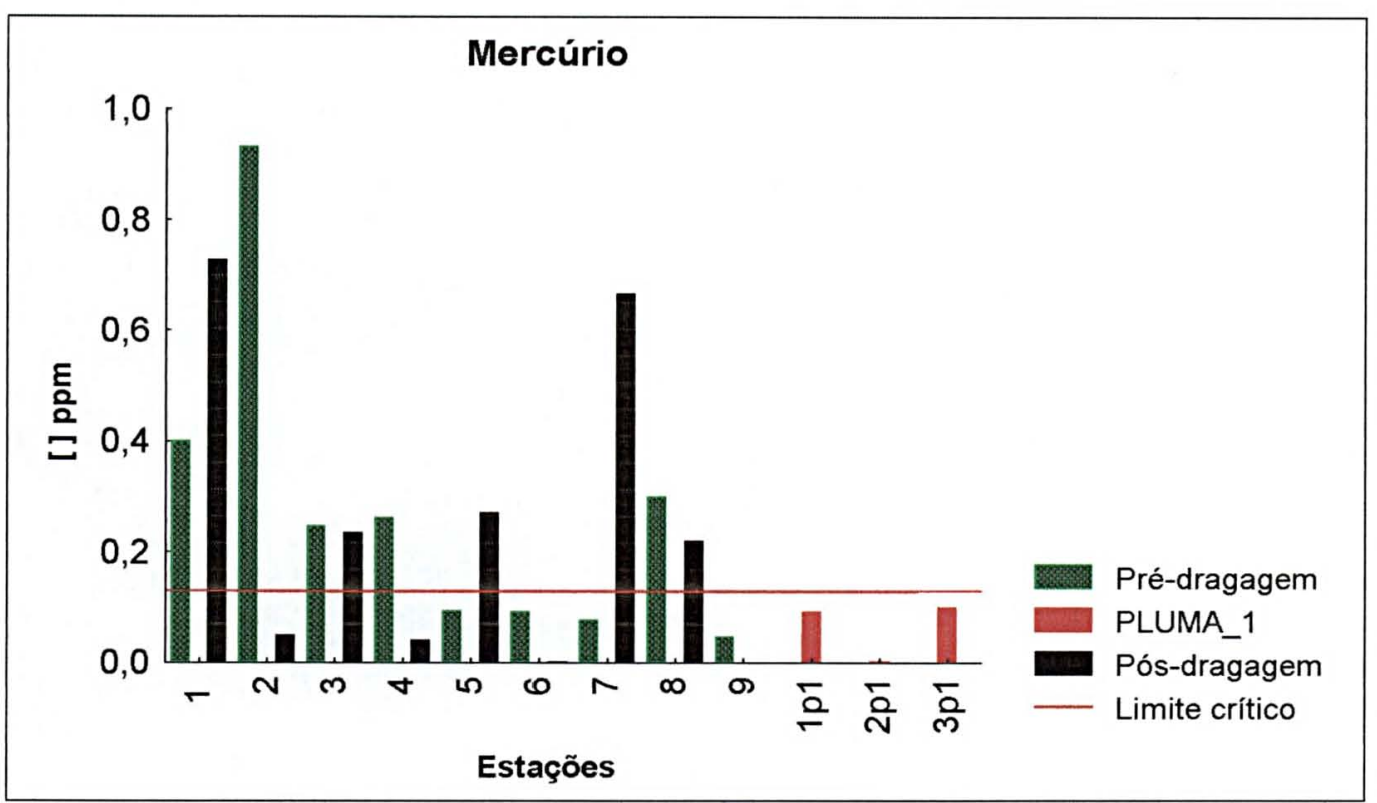

Figura 8 -. Concentrações de mercúrio (ppm) obtidos através de extração total (forte) em amostras de sedimento superficial das estações investigadas nas campanhas Pré-dragagem, Pluma 1 e Pós-Dragagem. A linha horizontal (em vermelho) representa o limite crítico específico $(0,13 \mathrm{ppm})$ para este metal.

\subsubsection{Cromo}

Não foram verificadas variações significativas nas concentrações parciais e totais de cromo nos sedimentos superficiais, entre as diferentes campanhas de amostragem efetuadas. Entretanto, as concentrações totais (extração forte) de cromo excederam o limite crítico adotado, de 52,3 ppm (Figura 9), em todas as campanhas efetuadas. Já as concentrações parciais (extração fraca) de cromo, estiveram bem abaixo do limite crítico adotado. 


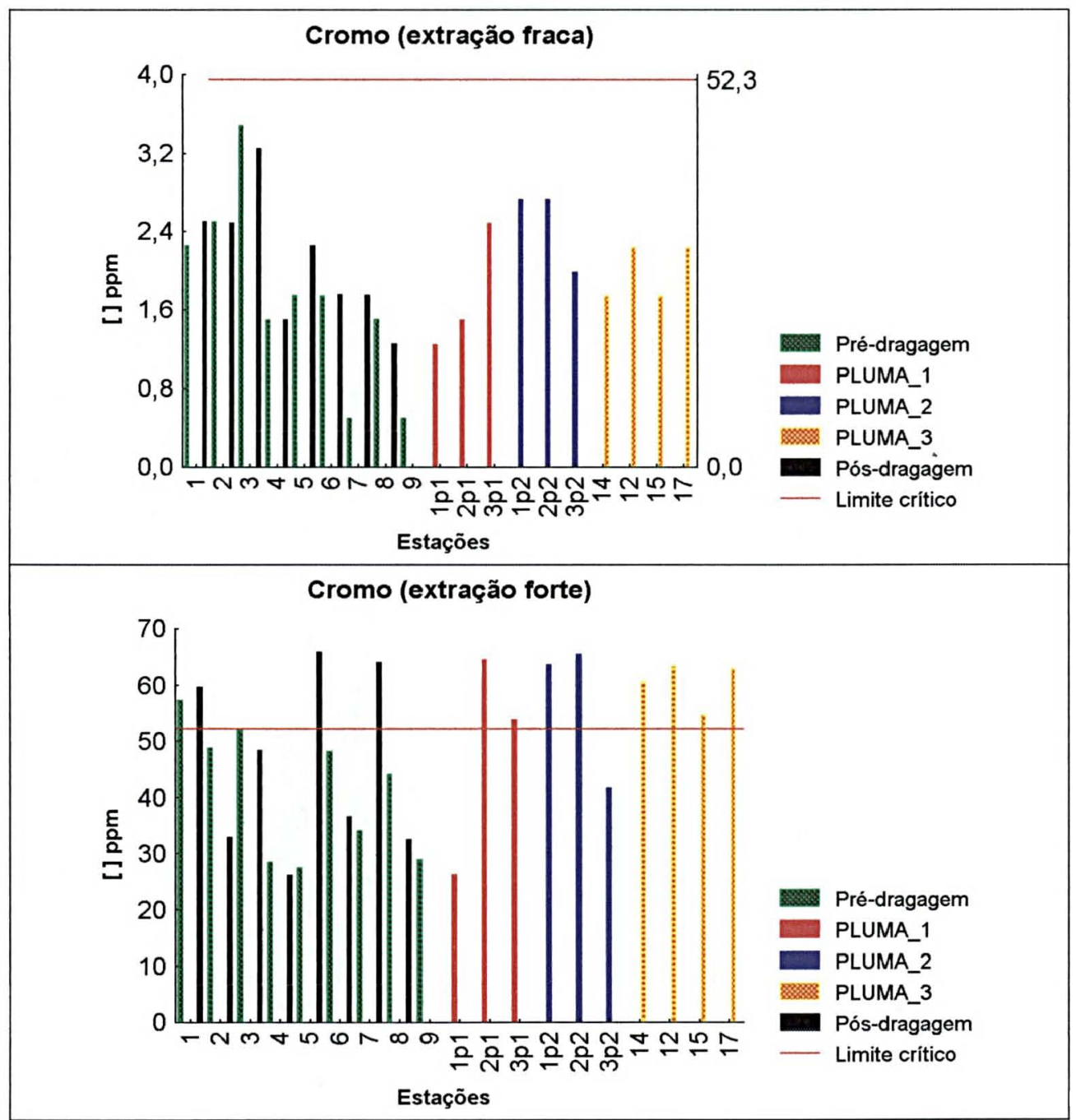

Figura 9 - Concentrações de cromo (ppm) obtidos através de extração total (forte) e parcial (fraca) em amostras de sedimento superficial das estações investigadas nas campanhas Pré-dragagem e Pós-Dragagem, bem como nas campanhas Plumas 1, 2 e 3. A linha horizontal (em vermelho) representa o limite crítico específico $(52,3 \mathrm{ppm})$ para este metal adotado na avaliação do grau de contaminação dos sedimentos.

\subsubsection{Cobre}

Variações temporais significativas $(p<0,05)$ foram detectadas para as concentrações médias totais e parciais de cobre, que apresentaram um incremento da Pré-dragagem até a Pluma 3, seguida de um decréscimo na Pós-dragagem (Figura 10). As concentrações parciais resultantes da extração fraca foram menores que as totais e sempre inferiores ao limite crítico adotado de 18,7 ppm. Estes resultados indicam que, se houve algum impacto das dragagens efetuadas pelos Terminais da Ponta do Félix, estas foram de curta duração. A importância de um contaminante para a biota relaciona-se à desordem orgânica que causa e à sua concentração no ambiente. No presente 
estudo, as concentrações totais de cobre estiveram, sempre, muito próximas ao limite crítico adotado. Isto significa que este metal deve ser considerado um contaminante importante para o ecossistema em questão.

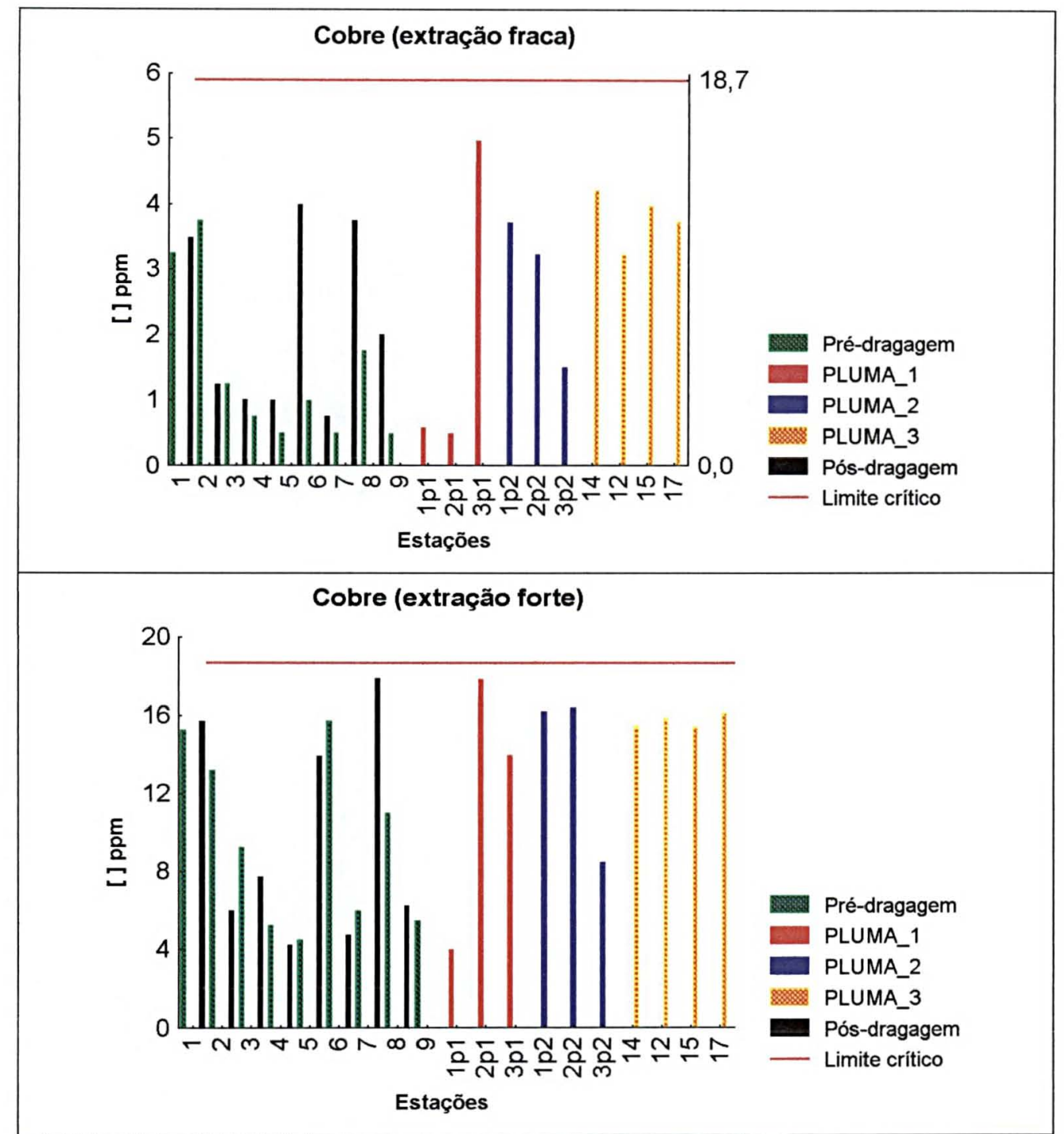

Figura 10 - Concentrações de cobre (ppm) obtidos através de extração total (forte) e parcial (fraca) em amostras de sedimento superficial das estações investigadas nas campanhas Pré-dragagem e Pós-Dragagem, bem como nas campanhas Plumas 1, 2 e 3. A linha horizontal (em vermelho) representa o limite crítico específico $(18,7 \mathrm{ppm})$ para este metal adotado na avaliação do grau de contaminação dos sedimentos.

\subsubsection{Chumbo}

As concentrações totais e parciais de chumbo registrados neste estudo, apresentaram um incremento significativo nas campanhas efetuadas durante as operações de dragagem (Plumas 1, 2 e 3), seguido de um decréscimo acentuado nas campanhas de Pós-dragagem (Figura 11). As concentrações 
totais registrados durante as Plumas 1 (estações $2 p 1$ e 3p1), 2 (estações $1 p 2$ e 2p2) e 3 (12 e 17) ultrapassaram o limite crítico adotado, de 30,24 ppm.

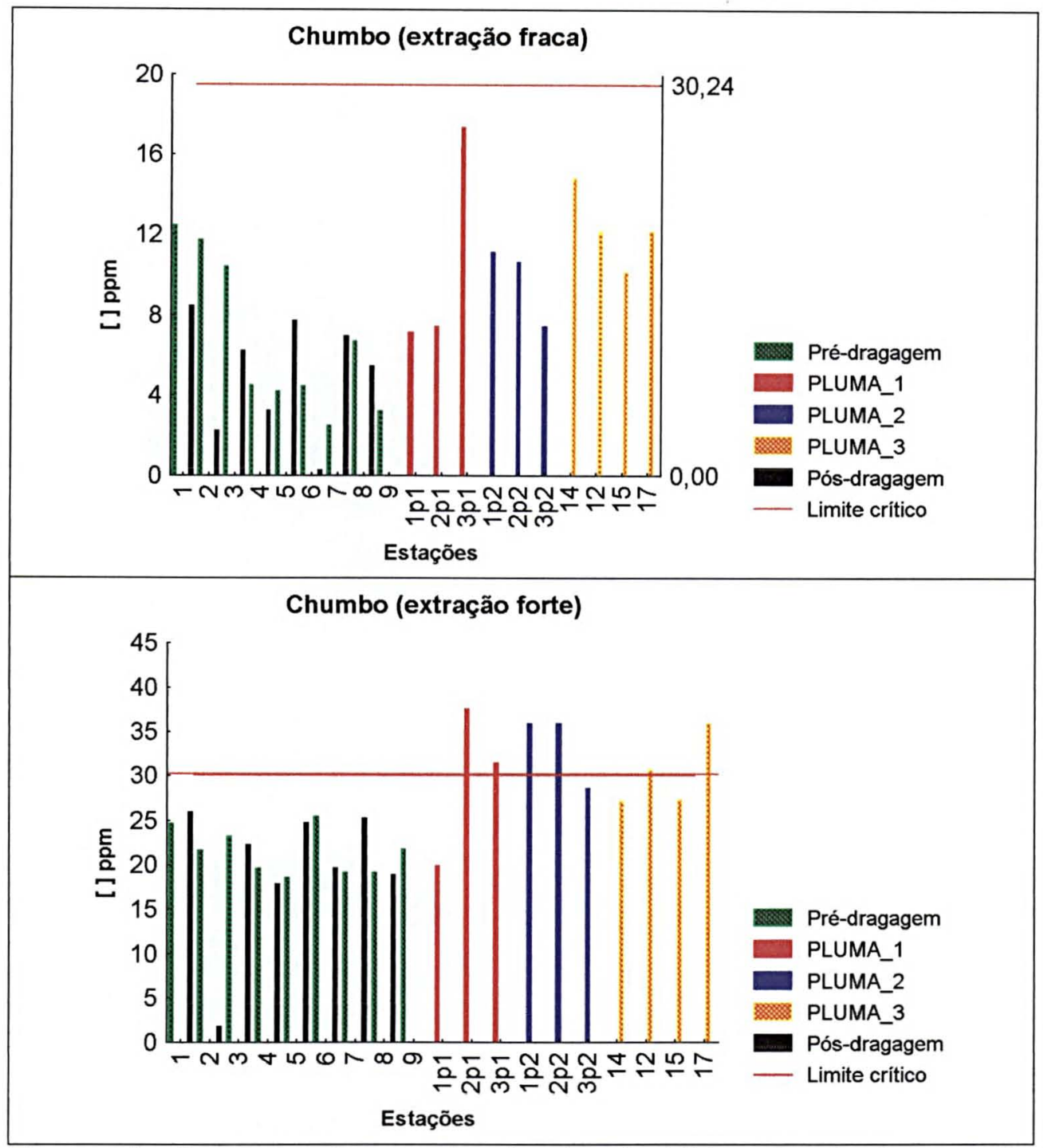

Figura 11 - Concentrações de chumbo (ppm) obtidos através de extração total (forte) e parcial (fraca) em amostras de sedimento superficial das estações investigadas nas campanhas Pré-dragagem e Pós-Dragagem, bem como nas campanhas Plumas 1,2 e 3 . A linha horizontal (em vermelho) representa o limite crítico específico $(30,24 \mathrm{ppm})$ para este metal.

\subsubsection{Cádmio}

O "teste $t$ " detectou um decréscimo significativo $(p<0,05)$ na concentração total (extração forte) de cádmio, da Pré-dragagem para a Pósdragagem (Figura 12). Porém, em todas as campanhas, as concentrações de cádmio total ultrapassaram o limite crítico de 0,676 ppm adotado. Já as concentrações parcial de cádmio (extração fraca), que representam as concentrações que estariam mais facilmente disponiveis para a biota, foram 
mais elevadas nas campanhas efetuadas durante as operações de dragagem (Plumas), mas não alcançaram os limites críticos adotados.

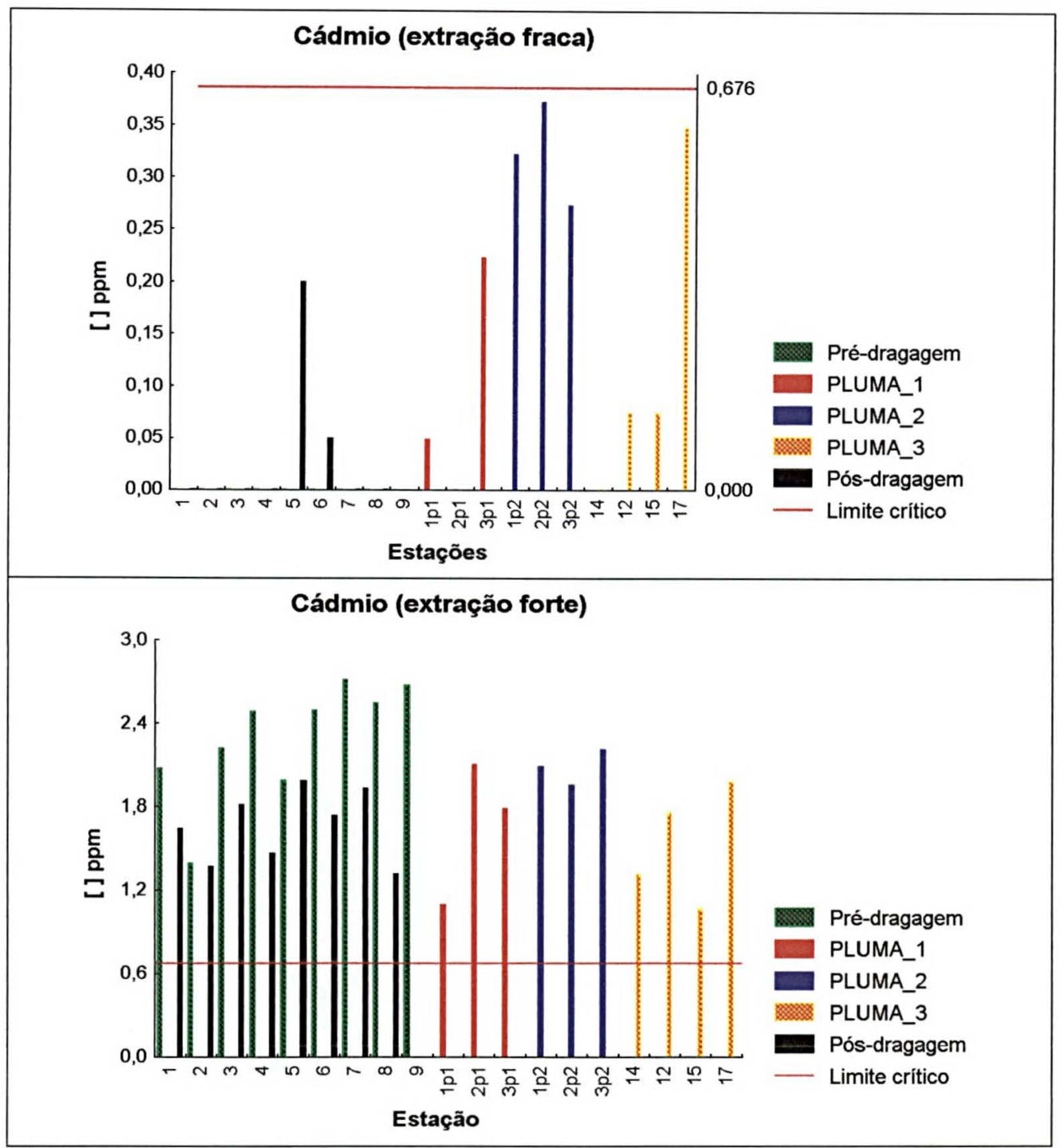

Figura 12 - Concentrações de cádmio (ppm) obtidos através de extração total (forte) e parcial (fraca) em amostras de sedimento superficial das estações investigadas nas campanhas Pré-dragagem e Pós-Dragagem, bem como nas campanhas Plumas 1, 2 e 3. A linha horizontal (em vermelho) representa o limite crítico específico $(0,676 \mathrm{ppm})$ para este metal adotado na avaliação do grau de contaminação dos sedimentos.

\subsubsection{Análise estatística}

As médias das concentrações (Tabelas 5 e 6) obtidas através das duas extrações, fraca e forte, demonstram que ocorreu variações em todos os elementos analisados, tanto de aumento quanto de diminuição de suas concentrações, em ambas as seções consideradas. 
Tabela 5 - Média das concentrações $(\mathrm{mg} / \mathrm{Kg})$ relativas à extração fraca em todas as seções consideradas (local) antes e depois da atividade de dragagem.

\begin{tabular}{cccccccc}
\hline \multirow{2}{*}{ Elementos } & \multicolumn{7}{c}{$\underline{\text { Secóes }}$} \\
\cline { 3 - 8 } (mg/Kg) & \multicolumn{2}{c}{ Canal dragado } & \multicolumn{2}{c}{ Despejo } & \multicolumn{2}{c}{ Não dragado } \\
\cline { 2 - 7 } & antes & depois & antes & depois & antes & depois \\
Cádmio & 0,0 & 0,067 & 0,0 & 0,0 & 0,0 & 0,025 \\
Chumbo & 7,57 & 5,15 & 6,489 & 6,228 & 6,05 & 3,25 \\
Cromo & 1,91 & 1,99 & 1,414 & 1,909 & 1,9 & 2,5 \\
Cobre & 1,99 & 2,41 & 1,468 & 2,741 & 0,91 & 0,87 \\
\hline
\end{tabular}

Tabela 6 - Média das concentrações $(\mathrm{mg} / \mathrm{Kg})$ relativas à extração forte em todas as seções consideradas (local) antes e depois da atividade de dragagem.

\begin{tabular}{|c|c|c|c|c|c|c|}
\hline \multirow{3}{*}{$\frac{\text { Elementos }}{(\mathrm{mg} / \mathrm{Kg})}$} & \multicolumn{6}{|c|}{ Seções } \\
\hline & \multicolumn{2}{|c|}{ Canal dragado } & \multicolumn{2}{|c|}{ Despejo } & \multicolumn{2}{|c|}{ Não dragado } \\
\hline & antes & depois & antes & depois & antes & depois \\
\hline Cádmio & 1,976 & 1,558 & 2,426 & 1,682 & 2,467 & 1,776 \\
\hline Chumbo & 19,844 & 15,183 & 21,192 & 23,046 & 23,517 & 20,987 \\
\hline Cromo & 40,11 & 43,748 & 39,907 & 49,904 & 43,073 & 42,465 \\
\hline Cobre & 9,551 & 8,699 & 8,817 & 12,6 & 10,147 & 6,207 \\
\hline Arsênio & 20,025 & 15,922 & 17,645 & 16,994 & 16,658 & 29,835 \\
\hline Níquel & 21,684 & 20,096 & 22,14 & 26,152 & 16,04 & 15,386 \\
\hline Mercúrio & 0,441 & 0,18 & 0,246 & 0,478 & 0,129 & 0,117 \\
\hline
\end{tabular}

A análise de teste - $t$ verificou se ocorreu variação significativa entre as estações como um todo, somente no canal dragado, no local de despejo e na seção não dragada, tanto para a extração fraca como para a extração forte. Os resultados estão apresentados nas tabelas 7 e 8 . Chumbo foi o único elemento que apresentou variação significativa (extração fraca) na seção canal dragado. O elemento cádmio apresentou variação significativa (extração forte) na seção despejo e global. 
Tabela 7 - Análise teste - $t$, relativa à extração fraca, nas diferentes seções da atividade de dragagem. ns - variação não significativa, ${ }^{\star \star}$ - variação significativa.

\begin{tabular}{ccccc}
\hline Teste $-\mathrm{t}$ & Cádmio & Chumbo & Cromo & Cobre \\
\hline $\begin{array}{c}\text { Global } \\
\text { antes } x \text { depois }\end{array}$ & ns & ns & ns & ns \\
$\begin{array}{c}\text { Canal } \\
\begin{array}{c}\text { antes } \times \text { depois } \\
\text { Despejo }\end{array}\end{array}$ & ns & $\star \star$ & ns & ns \\
$\begin{array}{c}\text { antes } x \text { depois } \\
\text { Não dragado } \\
\text { antes } \times \text { depois }\end{array}$ & ns & ns & ns & ns \\
\hline
\end{tabular}

Tabela 8 - Análise teste - $t$, relativa à extração forte, nas diferentes seções da atividade de dragagem. ns - variação não significativa, ${ }^{\star \star}$ - variação significativa.

\begin{tabular}{|c|c|c|c|c|c|c|c|}
\hline Teste - $t$ & Cádmio & Chumbo & Cromo & Cobre & Arsênio & Mercúrio & Níquel \\
\hline $\begin{array}{l}\text { Global } \\
\text { antes } x \\
\text { depois }\end{array}$ & $\star \star *$ & ns & ns & $\mathrm{ns}$ & ns & $\mathrm{ns}$ & ns \\
\hline $\begin{array}{l}\text { Canal } \\
\text { antes } x \\
\text { depois }\end{array}$ & ns & ns & ns & $\mathrm{ns}$ & $\mathrm{ns}$ & $\mathrm{ns}$ & ns \\
\hline $\begin{array}{l}\text { Despejo } \\
\text { antes } \mathrm{x} \\
\text { depois }\end{array}$ & ns & ns & ns & $\mathrm{ns}$ & ns & ns & $\mathrm{ns}$ \\
\hline $\begin{array}{l}\text { dragado } \\
\text { antes } x \\
\text { depois }\end{array}$ & $\star \star$ & ns & $\mathrm{ns}$ & ns & ns & $\mathrm{ns}$ & ns \\
\hline
\end{tabular}

Através da análise de agrupamento (Cluster), para as concentrações obtidas pela extração fraca (Figura 13), foi verificado que apenas a seção de despejo antes da atividade de dragagem não ficou agrupada com as demais. No outro grupo maior verifica-se um agrupamento não ordenado das seções de despejo depois da dragagem, canal dragado antes e depois da dragagem e a seção não dragada antes e depois da atividade de dragagem. 


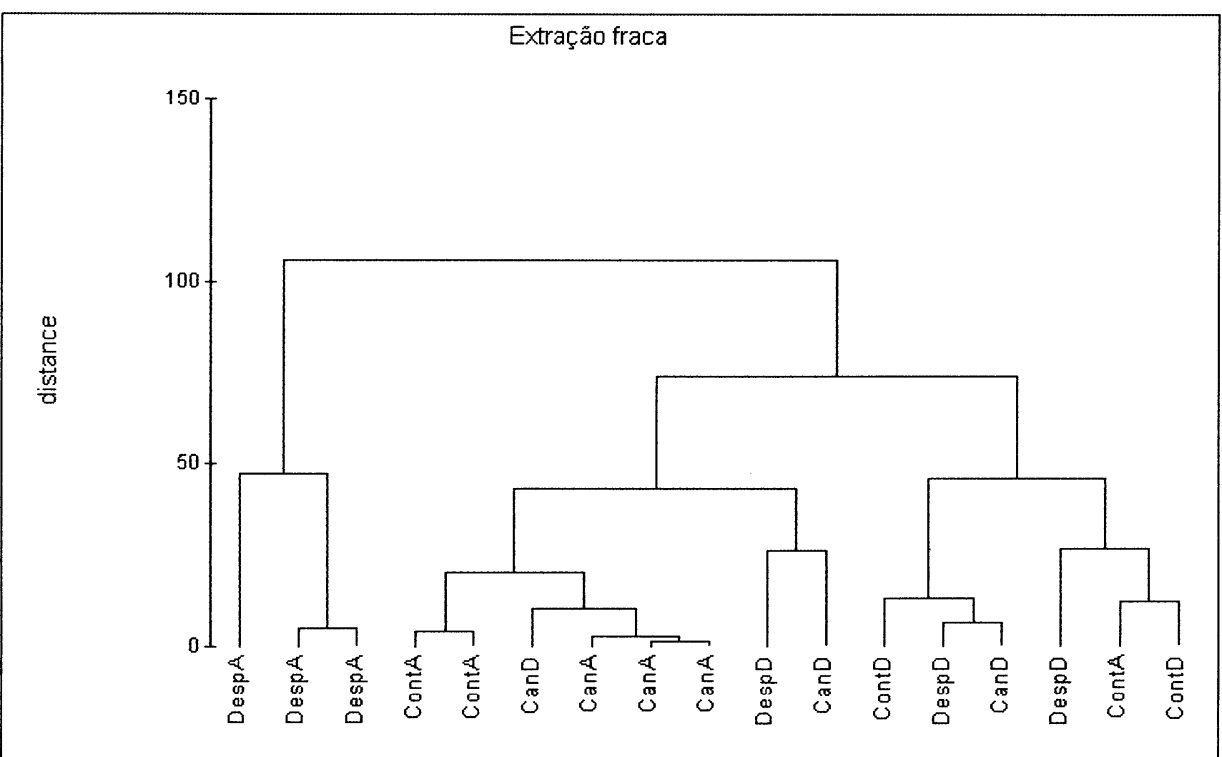

Figura 13 - Análise de agrupamento (Cluster) relativo à extração fraca. A - antes; D - depois; Can - canal dragado; Desp - despejo; Cont não dragado.

A análise de escalonamento multidimensional (MDS) dos elementos analisados na extração fraca (Figura 14) não demonstrou uma ordenação. Apenas confirmou o resultado obtido na análise de agrupamento, onde a todas as seções, tanto antes como depois da atividade de dragagem, foram agrupadas juntas.

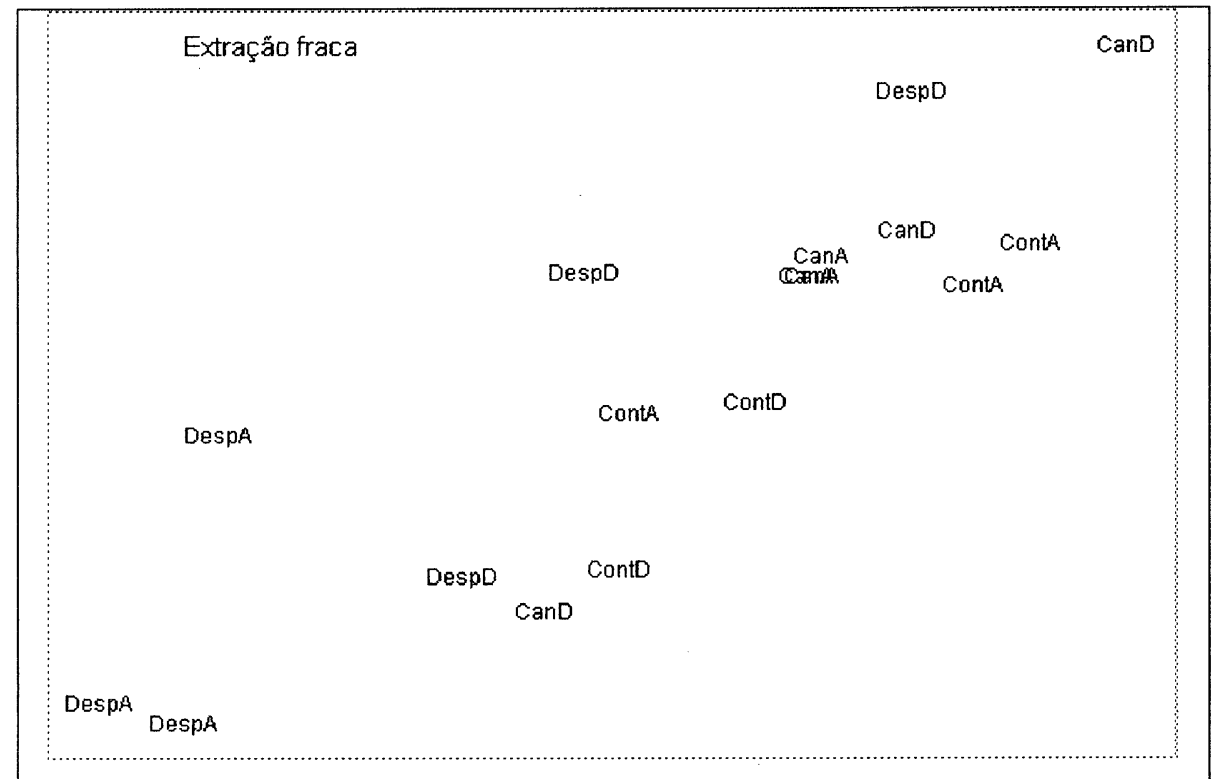

Figura 14 - MDS das seções durante as atividades de dragagem relativo à extração fraca. A - antes; D - depois; Can - canal dragado; Desp - despejo; Cont - não dragado.

Para as concentrações obtidas pela extração forte a análise de agrupamento (Cluster) (Figura 15) não demonstrou o mesmo agrupamento obtido para a extração fraca. Porém, as diferentes seções da atividade de 
dragagem também foram agrupadas juntas, em dois grandes grupos, gerando a mesma interpretação de que essa atividade influenciou toda a área estudada nessa etapa.

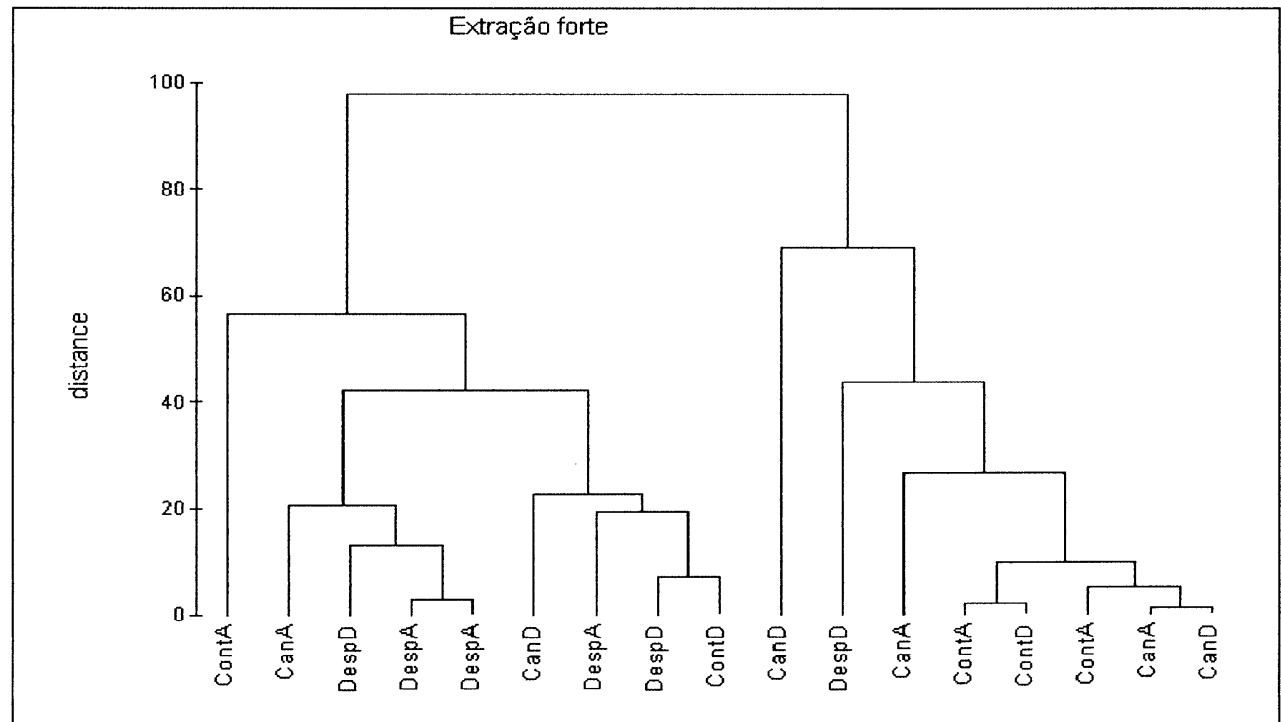

Figura 15 - Análise de agrupamento (Cluster) relativo à extração forte. A - antes; D - depois; Can - canal dragado; Desp - despejo; Cont - não dragado.

Para as concentrações obtidas através da extração forte a análise de escalonamento multidimensional (MDS) não apresentou uma ordenação das seções (Figura 16). Apenas demonstrou o comportamento já obtido pela análise anterior.

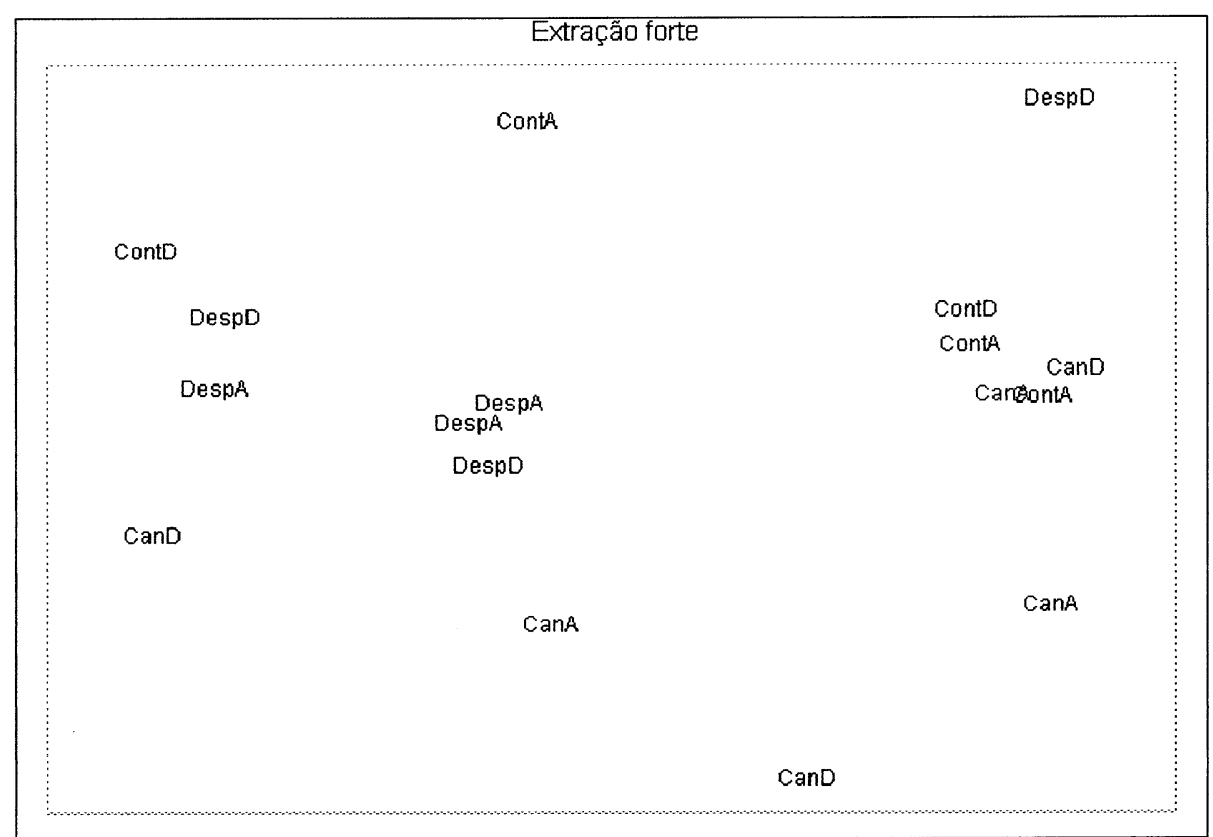

Figura 16 - MDS das seções durante as atividades de dragagem relativo à extração forte. A - antes; D - depois; Can - canal dragado; Desp - despejo; Cont - não dragado. 


\subsection{Segunda etapa: Avaliação e monitoramento da qualidade do sedimento nas imediações da indústria de fertilizantes FOSPAR - Baía de Paranaguá:}

Os resultados da primeira etapa complementar deste trabalho são apresentados na tabela 9 e nas figuras 17 a 33, e descritos a seguir.

Tabela 9 - Qualidade do sedimento na área do estudo, com base nos critérios reportados por Buchman, M.F. 1999; as concentrações mínimas e máximas dos indicadores obtidas em extrações fraca e forte do sedimento superficial em todas as campanhas de amostragem estão expressas em ppm $(\mathrm{mg} / \mathrm{Kg})$.

\begin{tabular}{|c|c|c|c|c|c|c|}
\hline Indicador & $\begin{array}{l}\text { Limites } \\
\text { críticos * }\end{array}$ & Extração & $\operatorname{Jan} / 2001$ & Mai/2001 & Ago/2001 & Nov/2001 \\
\hline \multirow[t]{2}{*}{ Arsênio } & 7,24 & Total & $<0,0001-50,5$ & $<0,0001-38,9$ & $<0.0001-77,8$ & $4,7-81,5$ \\
\hline & & Parcial & $<0,0001-5,0$ & $<0,0001-5,9$ & $<0,0001-5,4$ & $<0,0001-1,6$ \\
\hline \multirow[t]{2}{*}{ Cádmio } & $0,676(5)$ & Total & $0,06-0,45$ & $0,07-0,38$ & $0,06-0,58$ & $0,06-0,87$ \\
\hline & & Parcial & $<0,0001-0,11$ & $<0,0001-0,15$ & $<0,0001-0,17$ & $\begin{array}{c}<0,0001- \\
0,25\end{array}$ \\
\hline \multirow[t]{2}{*}{ Cobre } & $18,7(10)$ & Total & $1,2-21,95$ & $0,84-22,97$ & $0,70-10,65$ & $0,74-20,83$ \\
\hline & & Parcial & $0,19-4,47$ & $<0,0001-0,10$ & $0,10-4,17$ & $0,18-2,70$ \\
\hline \multirow[t]{2}{*}{ Cromo } & $52,3(25)$ & Total & $7,48-37,3$ & $5,05-40,50$ & $<0,0001-29,4$ & $6,34-44,61$ \\
\hline & & Parcial & $<0,1$ & $<0,1-6,16$ & $<0,1-6,07$ & $<0,1-11,90$ \\
\hline \multirow[t]{2}{*}{ Níquel } & $15,9(* *)$ & Total & $8,39-36,94$ & $0,97-38,35$ & $<0,1-24,79$ & $2,61-37,29$ \\
\hline & & Parcial & $<0,1-1,97$ & $<0,1-1,65$ & $<0,1-1,9$ & $<0,1-58,50$ \\
\hline \multirow[t]{2}{*}{ Zinco } & $124(20)$ & Total & $6,48-90,3$ & $0,74-90,6$ & $<0,4-310,8$ & $<0,4-82,2$ \\
\hline & & Parcial & $0,85-44,1$ & $0,70-42,3$ & $0,44-39,4$ & $<0,4-33,8$ \\
\hline \multirow[t]{2}{*}{ Mercúrio } & $0,13(0,1)$ & Total & $0,02-0,089$ & $0,005-0,078$ & $0,006-0,065$ & $0,002-0,116$ \\
\hline & & Parcial & ND & ND & ND & ND \\
\hline \multirow[t]{2}{*}{ Chumbo } & 30,24 & Total & $1,84-8,42$ & $2,52-9,59$ & $1,85-4,81$ & $2,91-12,95$ \\
\hline & (20) & Parcial & $<0,0001-0,2$ & $<0,0001-0,4$ & $<0,0001-0,2$ & $<0,0001-0,1$ \\
\hline
\end{tabular}

Nota: Valores entre parênteses referem-se aos limites estabelecidos pela legislação brasileira (SEMA, 1980). * Canadian Sediment Quality Guidelines e NOAA policy. ** Não possuem limites estabelecidos pela legislação brasileira. ND - não determinado.

\subsubsection{Arsênio}

As concentrações parcial e total de arsênio sofreram um incremento significativo $(p<0,05)$ ao longo do período investigado (Figura 17). Verificou-se que os maiores teores totais ocorreram em novembro de 2001, nas estações 4 , $8,10,11$ e 12. A maior concentração parcial, foi registrada na estação 12 (de 
referência), a qual não sofre impacto direto das atividades industriais. O limite crítico para o arsênio adotado neste estudo, de 7,24 ppm é bastante conservativo, porém assegura com alto grau de confiança que, se as concentrações encontradas no ambiente forem iguais ou inferiores a este valor, não há risco para a biota aquática. Porém as concentrações totais máximas de arsênio (Tabela 9) ultrapassaram até mesmo os valores que apresentam efeitos tóxicos, de 70 ppm (Buchman, 1999).

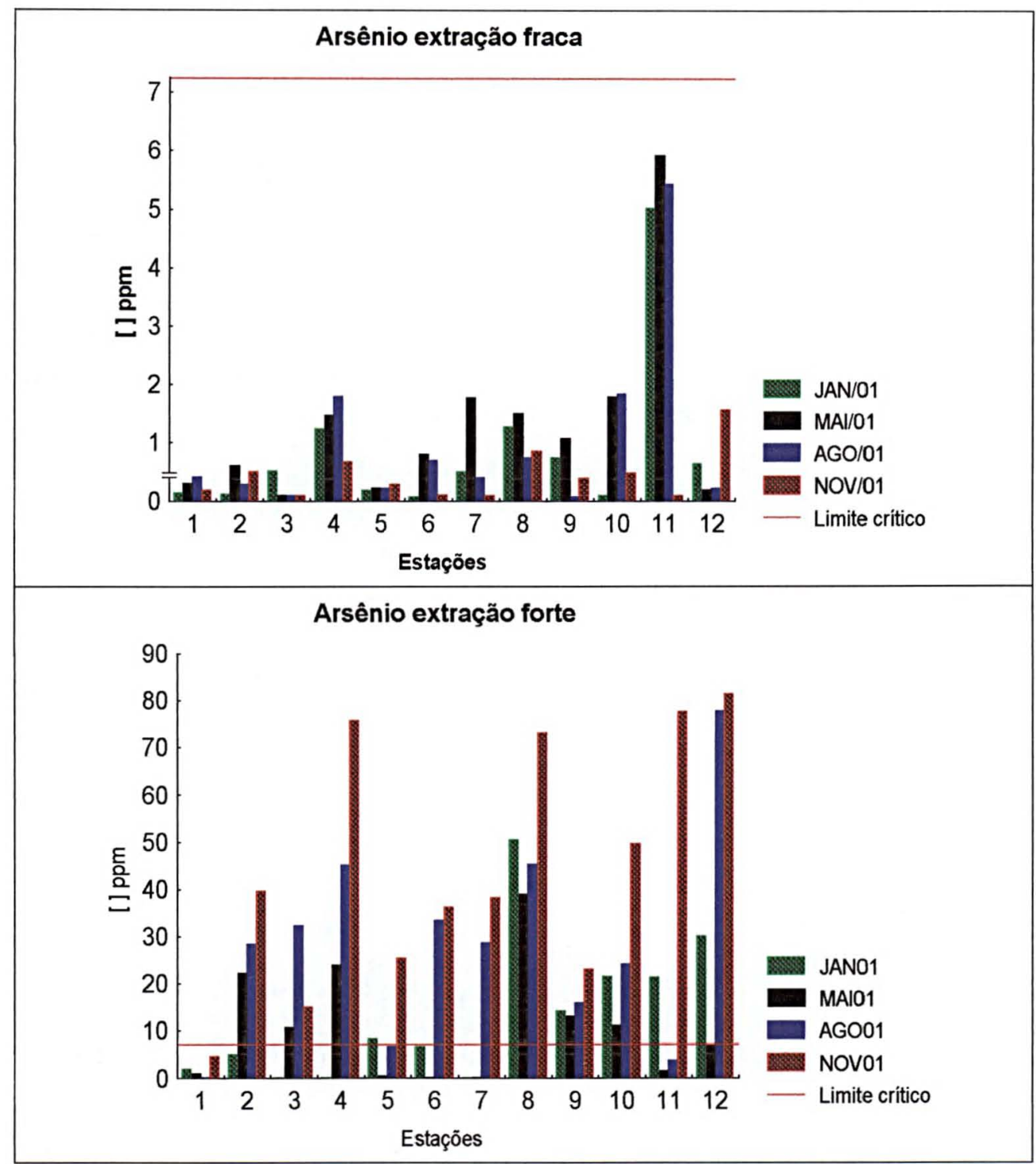

Figura 17 - Concentrações de arsênio (ppm) obtidas através de extração total e parcial em amostras de sedimento superficial das 12 estações investigadas. A linha horizontal (em vermelho) representa o limite crítico específico para este metal $(7,24 \mathrm{ppm})$ adotado na avaliação do grau de contaminação dos sedimentos.

A média das concentrações de arsênio (Figura 18) relativas as extrações fraca e forte mostram o comportamento deste elemento no período investigado. 
Quanto à extração fraca, ocorre um aumento de concentração na estação 11 (Rio Itiberê) a qual recebe despejo de esgoto doméstico. Já as concentrações médias relativas à extração forte estiveram sempre acima do limite crítico, apresentando maiores valores nas estações 8 e 12 .

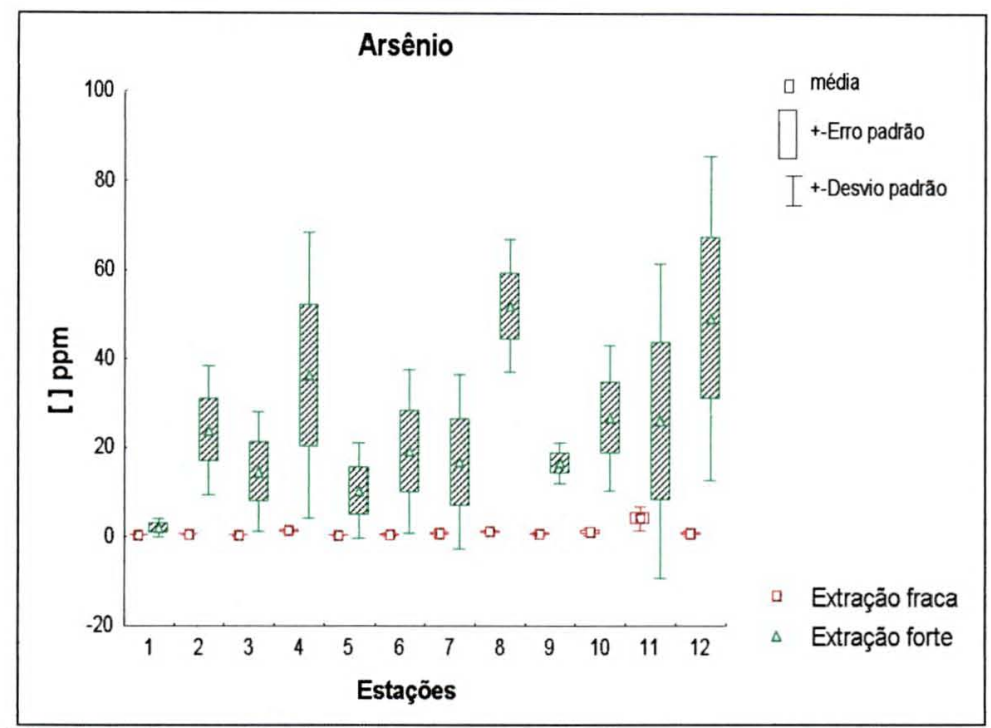

Figura 18 - Variação temporal das concentrações de arsênio nos sedimentos superficiais.

\subsubsection{Cádmio}

Os valores das concentrações parcial e total de cádmio apresentaram variações significativas ao longo do período investigado $(p<0,002252)$. A estação 9 durante o mês de novembro apresentou concentração de cádmio, com extração forte, superior ao limite crítico adotado de 0,676 ppm, sendo as demais concentrações encontradas abaixo deste limite, tanto na extração fraca quanto na extração forte (Figura 19). 


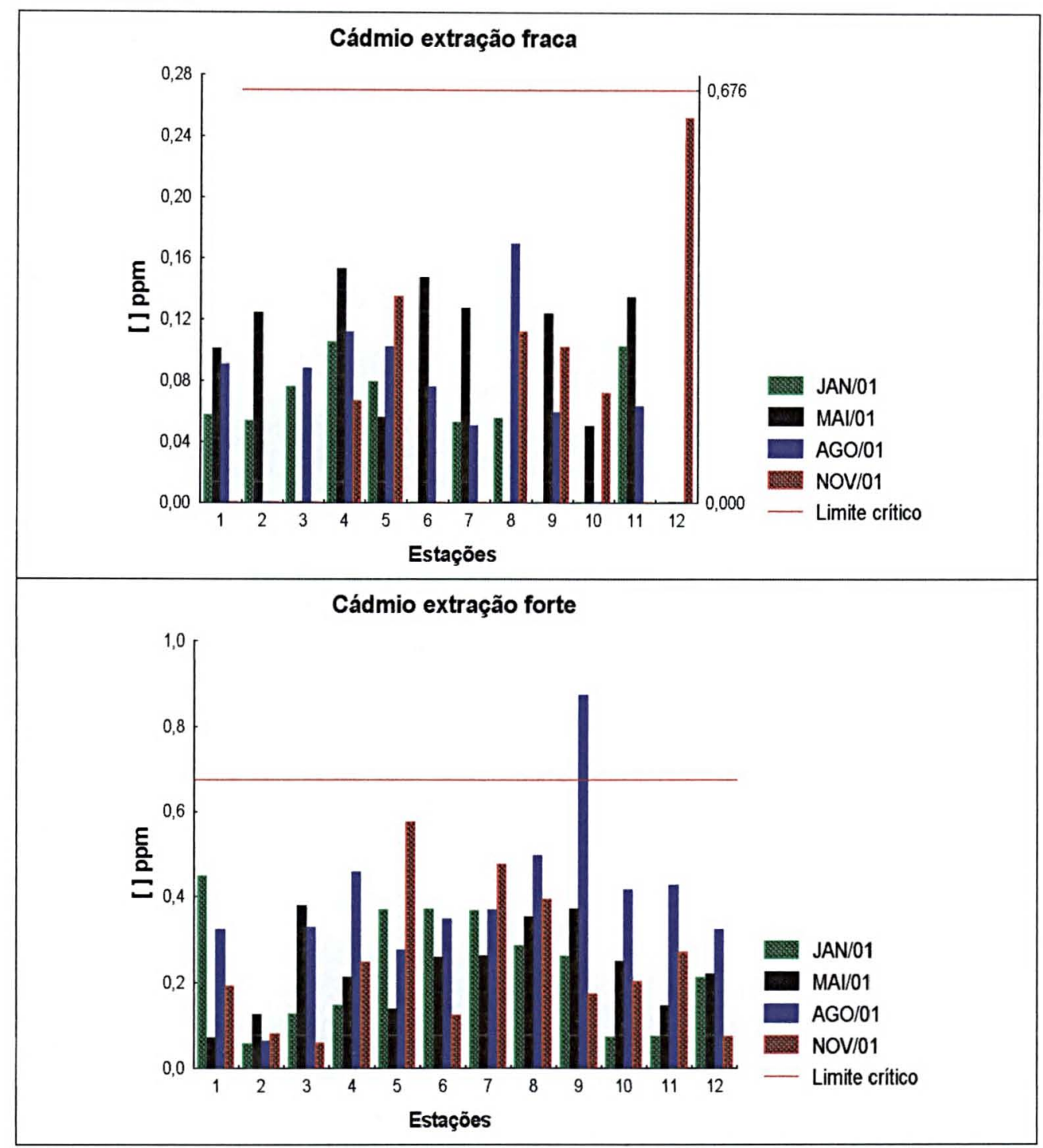

Figura 19 - Concentrações de cádmio (ppm) obtidas através de extração total e parcial em amostras de sedimento superficial das 12 estações investigadas. A linha horizontal (em vermelho) representa o limite crítico específico para este metal $(0,67 \mathrm{ppm})$ adotado na avaliação do grau de contaminação dos sedimentos.

A média das concentrações de cádmio relativas à extração forte (Figura 20) mostram que os valores mais elevados estão presentes nas estações 5,7 , 8 e 9, ambas nas imediações do terminal da indústria de fertilizantes local. Porém, não ultrapassam o valor do limite crítico adotado. Quanto à extração forte o maior valor médio foi registrado na estação 4 , também nas imediações deste terminal, mas todas as estações apresentam concentrações bem abaixo do limite crítico. 


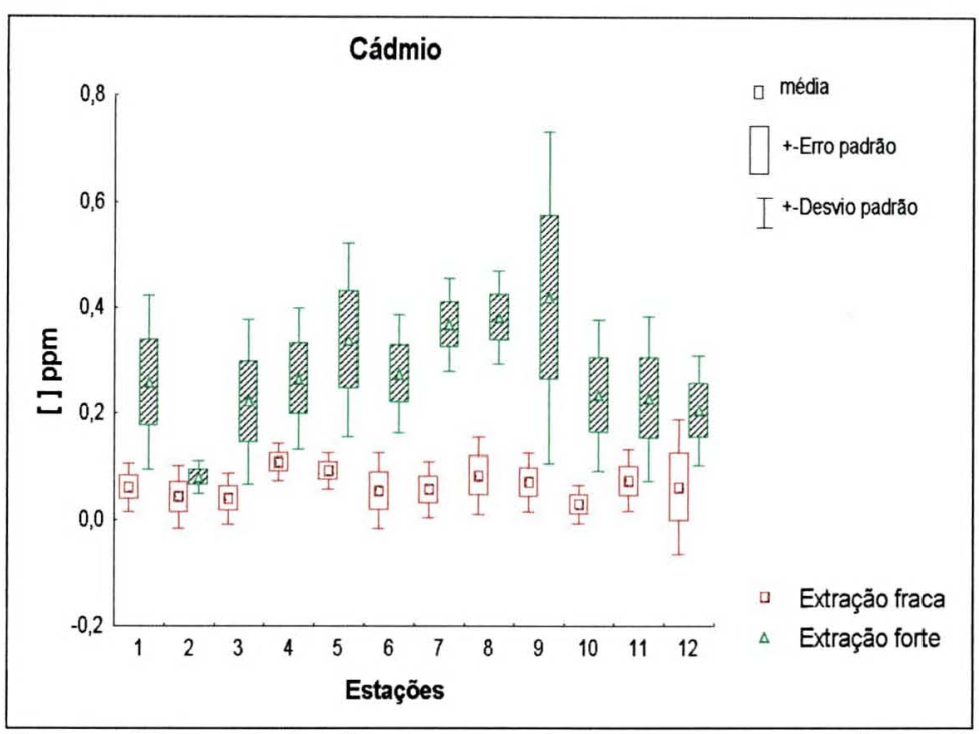

Figura 20 - Variação temporal das concentrações de cádmio nos sedimentos superficiais.

\subsubsection{Cromo}

Para o elemento cromo foram encontrados valores de concentração (Figura 21) abaixo do limite crítico de 52,3 ppm em ambas as extrações, não apresentando variações significativas. Durante o mês de janeiro e em algumas amostras nos outros meses desta etapa, as concentrações de cromo com extração fraca em todas as estações, estiveram praticamente abaixo do limite de detecção. Nas análises efetuadas pela extração forte observa-se que as estações 4, 7 e 11 apresentam concentrações próximas ao limite crítico, sendo que na estação 7 no mês de novembro foi registrada a concentração mais elevada. 


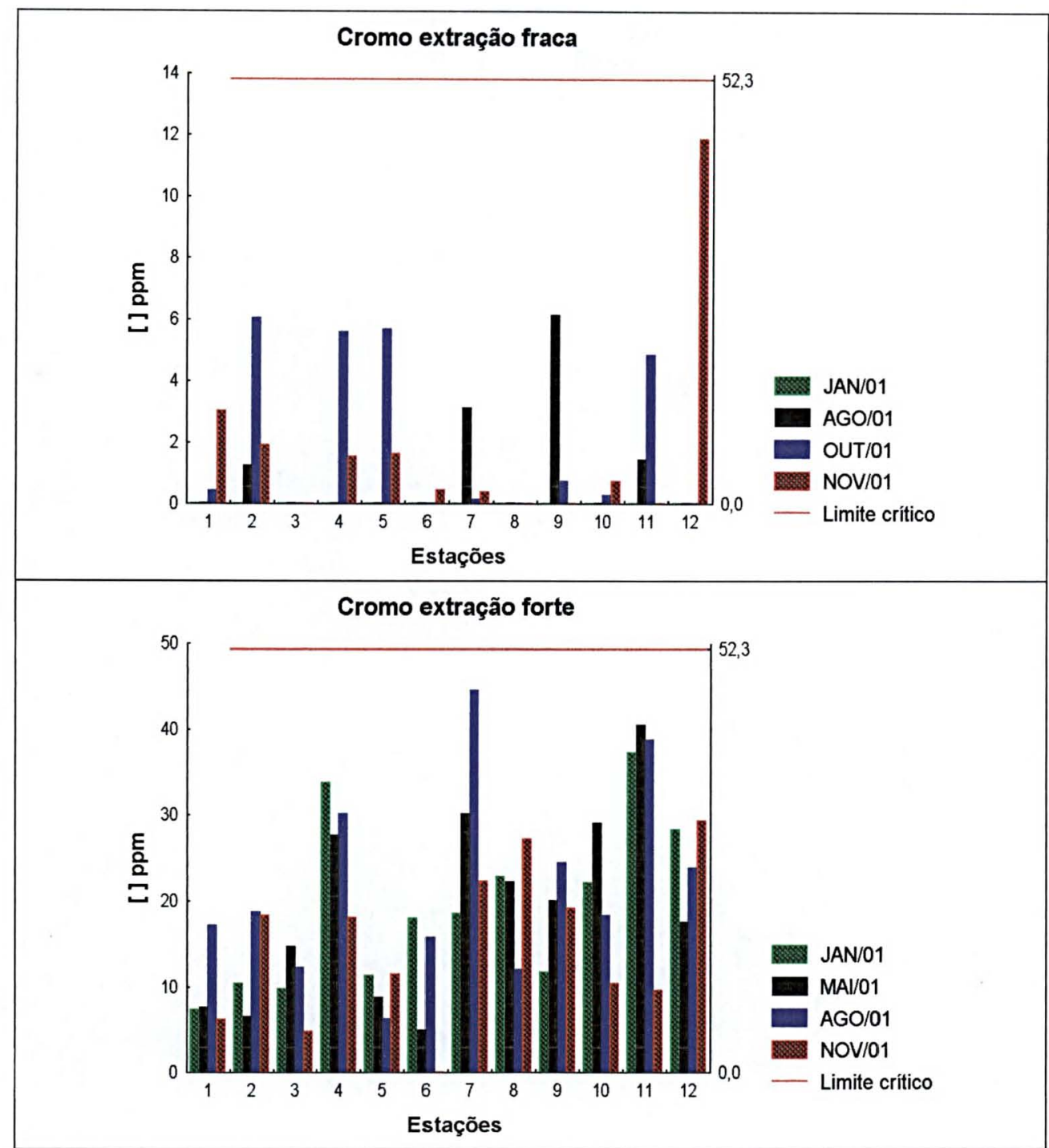

Figura 21 - Concentrações de cromo (ppm) obtidas através de extração total e parcial em amostras de sedimento superficial das 12 estações investigadas. A linha horizontal (em vermelho) representa o limite crítico específico para este metal (52,3 ppm) adotado na avaliação do grau de contaminação dos sedimentos.

Quanto à extração fraca a média das concentrações (Figura 22) apresentam maiores valores nas estações 2 e 12, porém, esta última possui elevado desvio padrão ocasionado pela diferença de concentrações encontradas nos meses investigados. Para a extração forte a maior média foi registrada na estação 11 , mas todas as concentrações médias encontradas estão abaixo do limite crítico. 


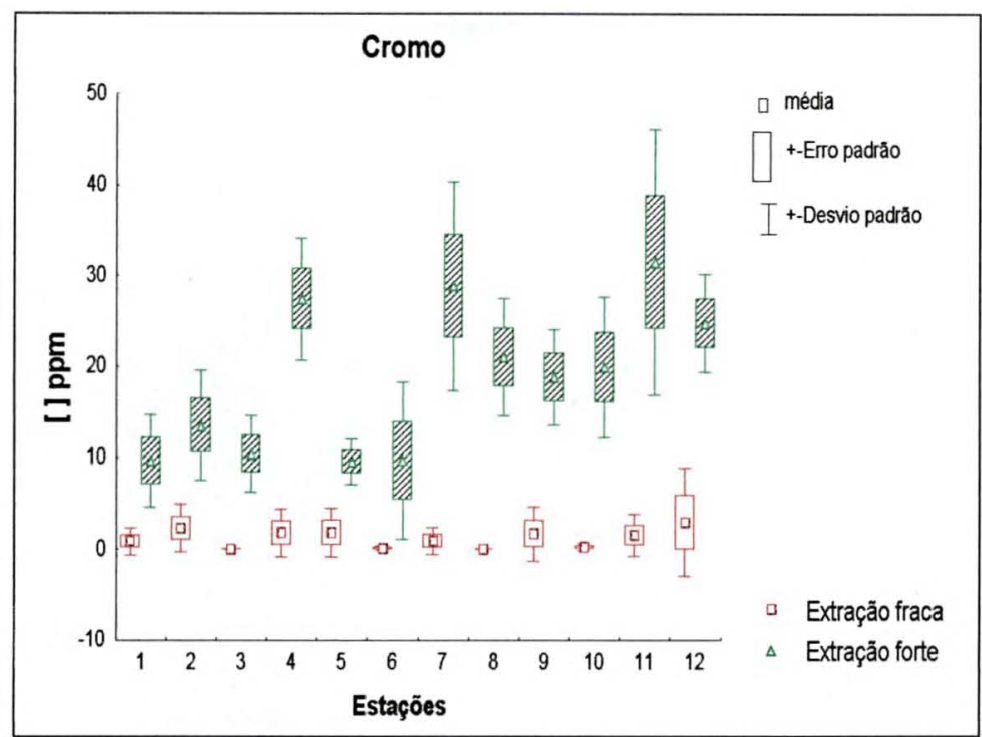

Figura 22 - Variação temporal dos teores de cromo nos sedimentos superficiais durante o período investigado.

\subsubsection{Cobre}

As concentrações de cobre obtidas pela extração fraca apresentaram maiores valores nas estações 4, 8 e especialmente na 11, onde verificou-se concentrações elevadas nas três primeiras campanhas desta etapa. O mesmo comportamento foi observado com a extração forte: a estação 11 do Rio Itiberê apresentou concentrações que excederam o limite crítico de 18,7 ppm nos três primeiros meses. Nas demais estações as concentrações de cobre ficaram abaixo do limite crítico, sendo que a estação 1 no Rio Emboguaçu apresentou as menores concentrações (Figura 23). 


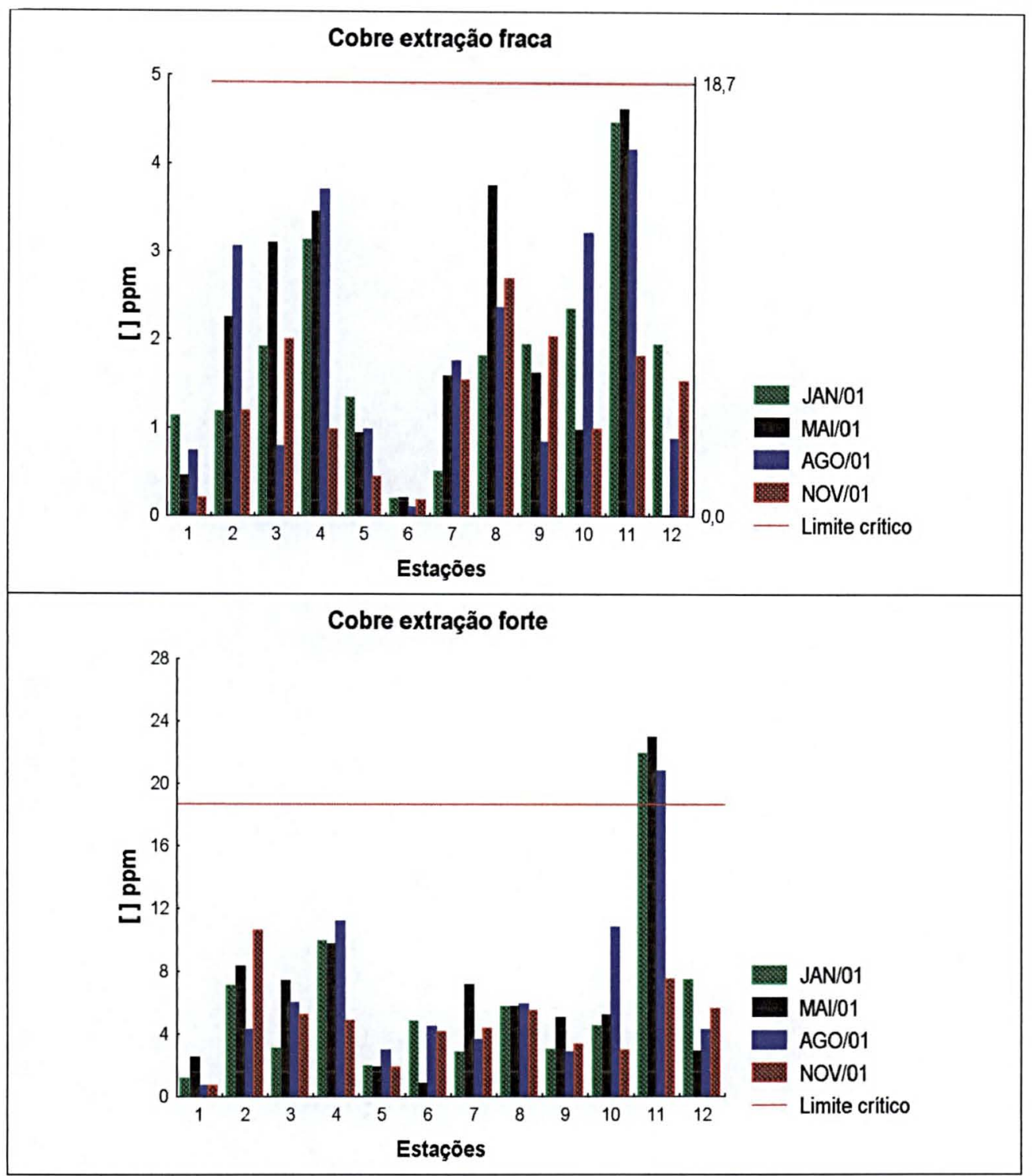

Figura 23 - Concentrações de cobre (ppm) obtidos através de extração total e parcial em amostras de sedimento superficial das 12 estações investigadas. A linha horizontal (em vermelho) representa o limite crítico específico para este metal (18,7 ppm) adotado na avaliação do grau de contaminação dos sedimentos.

A média das concentrações de cobre (Figura 24) relativas à extração forte ressaltam a estação $11 \mathrm{em}$ relação as demais. Para a extração fraca a maior média também foi registrada na estação 11 , sendo este tipo de extração relacionada à disponibilidade do elemento. Isto indica que este local recebe grande aporte deste elemento metálico. 


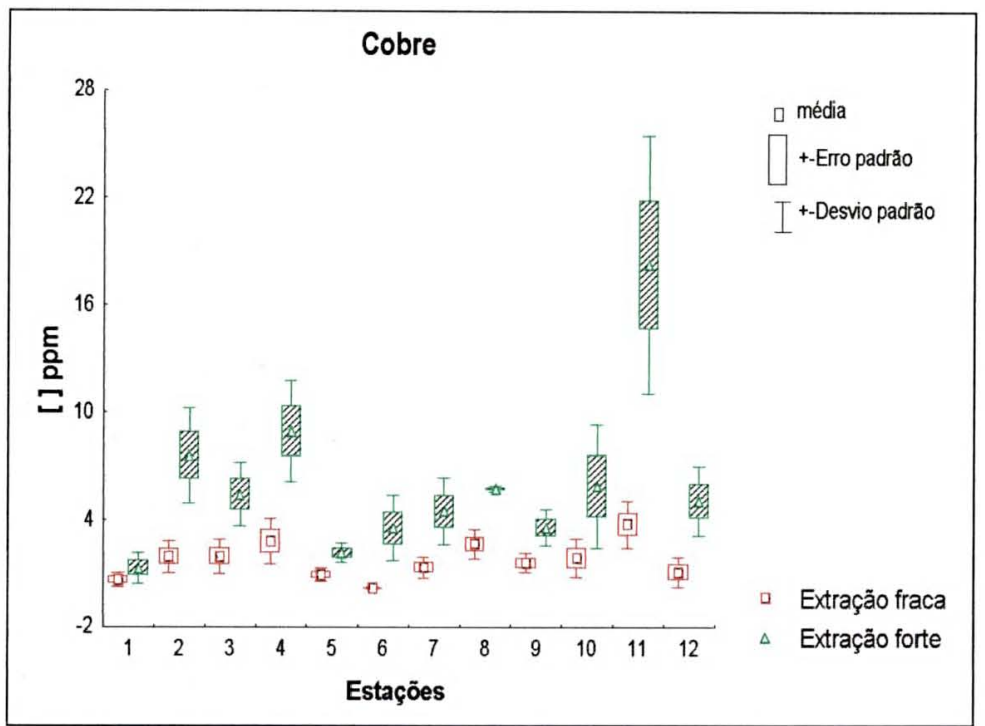

Figura 24 - Variação temporal dos teores de cobre nos sedimentos superficiais durante o período investigado.

\subsubsection{Níquel}

Em geral, as concentrações obtidas através da extração fraca foram muito baixos. A concentração elevada registrada na estação 12 no mês de novembro foi, provavelmente, decorrente de um erro analítico ou contaminação da amostra e foi descartada para a realização da discussão destes resultados. $\mathrm{Na}$ extração forte, as concentrações de níquel ultrapassaram o valor do limite crítico de 15,9 ppm em todas as estações, exceto nas estações 1 e 2, sendo que as estações 4 e 11 apresentaram as maiores concentrações (respectivamente $37,3 \mathrm{mg} / \mathrm{Kg}$ e $38,3 \mathrm{mg} / \mathrm{Kg}$ ) (Figura 25). 


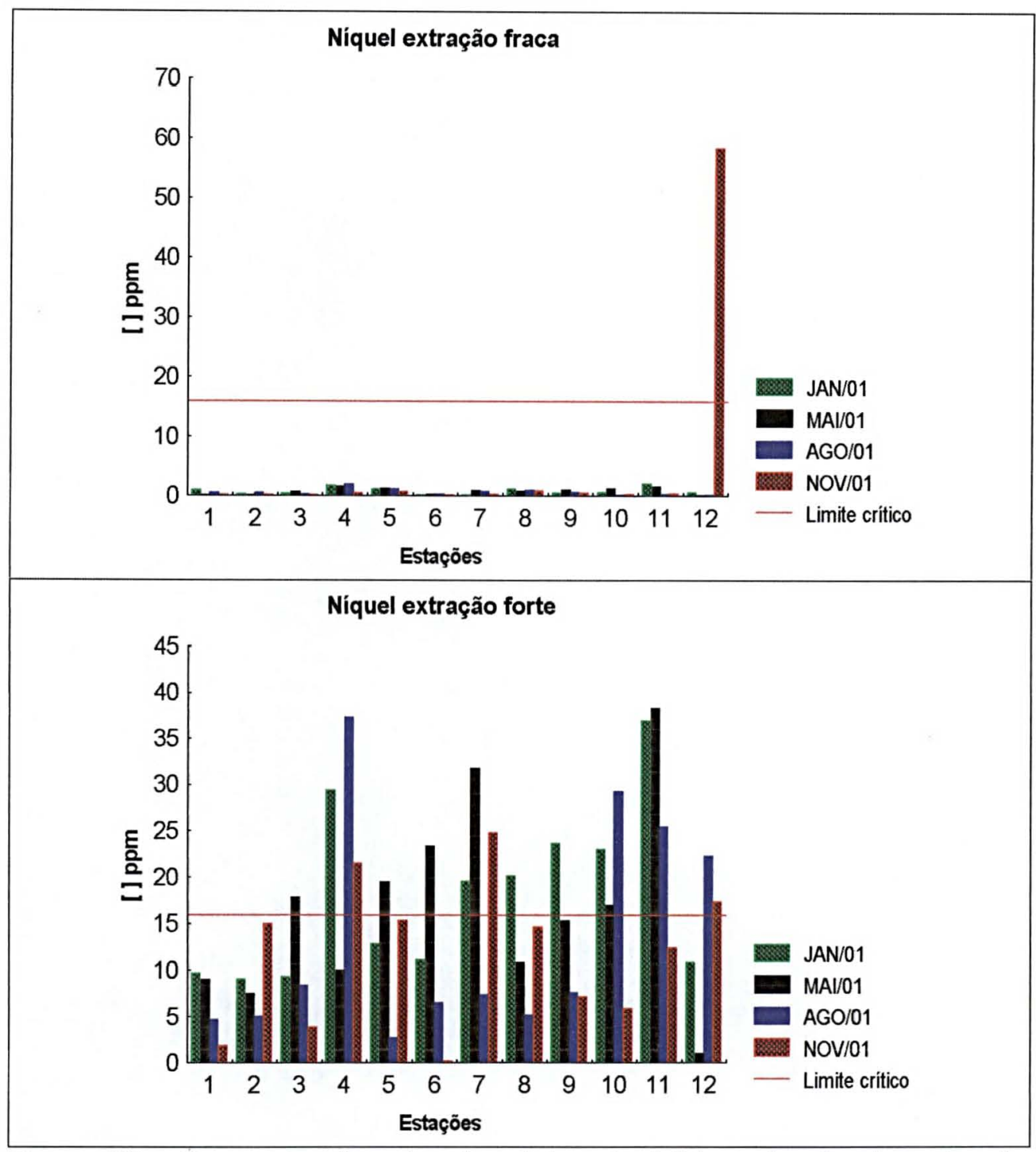

Figura 25 - Concentrações de níquel (ppm) obtidos através de extração total e parcial em amostras de sedimento superficial das 12 estações investigadas. A linha horizontal (em vermelho) representa o limite crítico específico para este metal (15,9 ppm) adotado na avaliação do grau de contaminação dos sedimentos.

Quanto à extração fraca a variação encontrada na estação 12 já foi abordada acima e descartada, nas demais estações as concentrações médias permaneceram com valores bem baixos (Figura 26). Para a extração forte há um incremento deste elemento nas estações 4,7 e 11, sendo estes valores médios acima do limite crítico. 


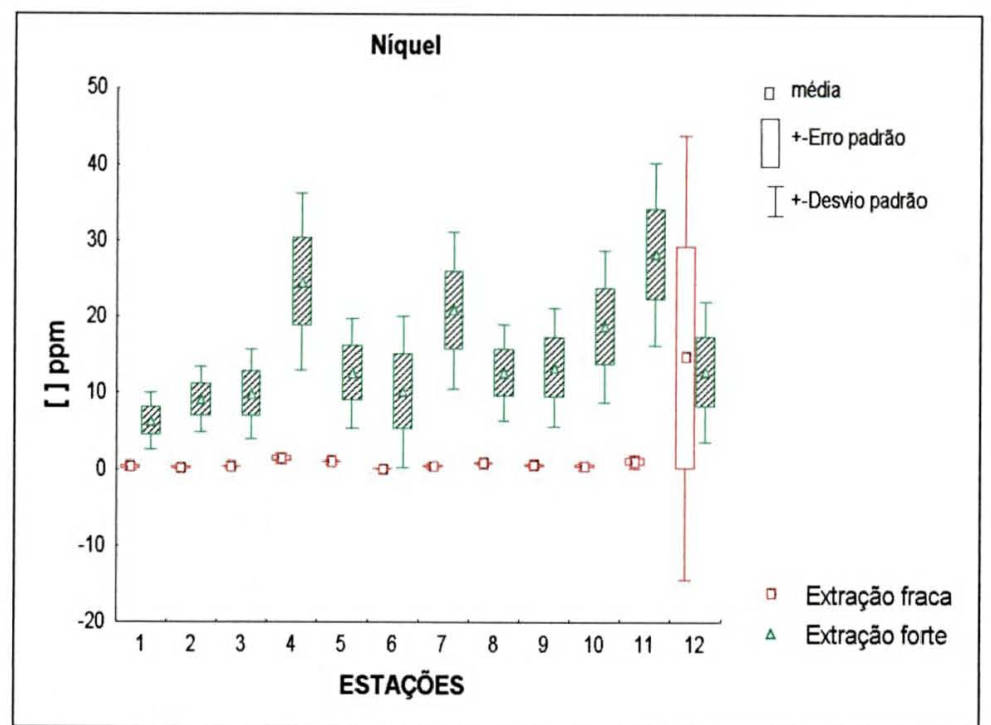

Figura 26 - Variação temporal das concentrações de níquel nos sedimentos superficiais durante o período investigado.

\subsubsection{Chumbo}

$\mathrm{Na}$ extração fraca, os valores das concentrações de chumbo foram baixos inclusive não detectados em algum dos meses investigados, tendo a estação 2 do Canal do Anhaia as concentrações mais elevadas. Mesmo com a extração forte as concentrações de chumbo mantiveram-se bem abaixo do limite crítico de 30,2 ppm (Figura 27). A estação 4 apresentou a maior concentração durante o mês de novembro. Estes resultados diferem dos obtidos pela administração dos portos de Paranaguá e Antonina (APPA) em 1998/1999 que apontou o elemento chumbo como um dos que ultrapassaram o limite adotado pela APPA. 


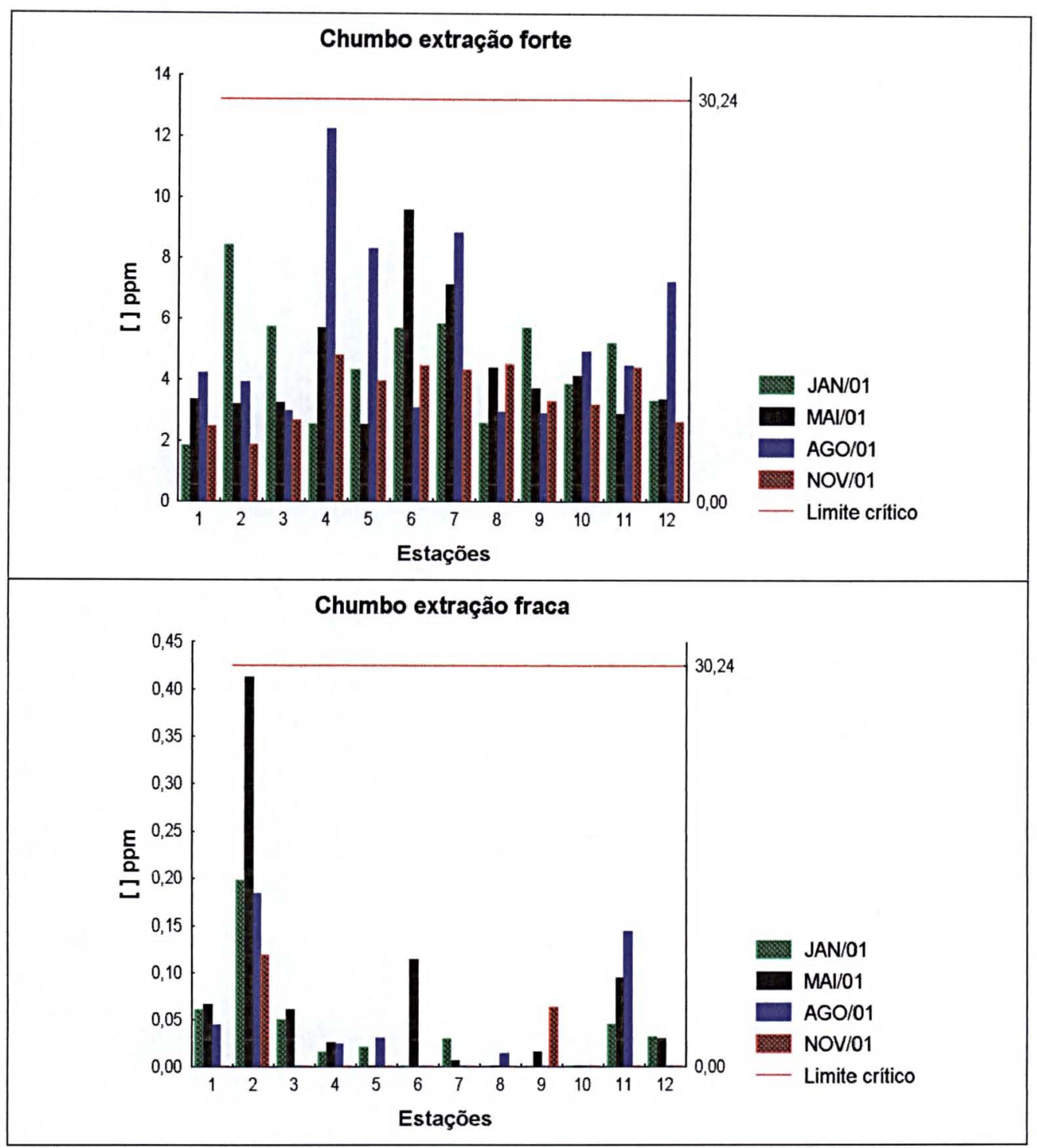

Figura 27 - Concentrações de chumbo (ppm) obtidos através de extração total e parcial em amostras de sedimento superficial das 12 estaçôes investigadas. A linha horizontal (em vermelho) representa o limite crítico específico para este metal $(30,2 \mathrm{ppm})$ adotado na avaliação do grau de contaminação dos sedimentos.

Apesar das concentrações apresentarem valores abaixo do limite crítico, a média das concentrações (Figura 28) apresentaram valores, praticamente constantes e baixos, quanto à extração fraca. Para a extração forte as estações 4, 6 e7 apresentaram maiores médias, porém analisando o desvio padrão verifica-se que não há variação significativa entre as estações. 


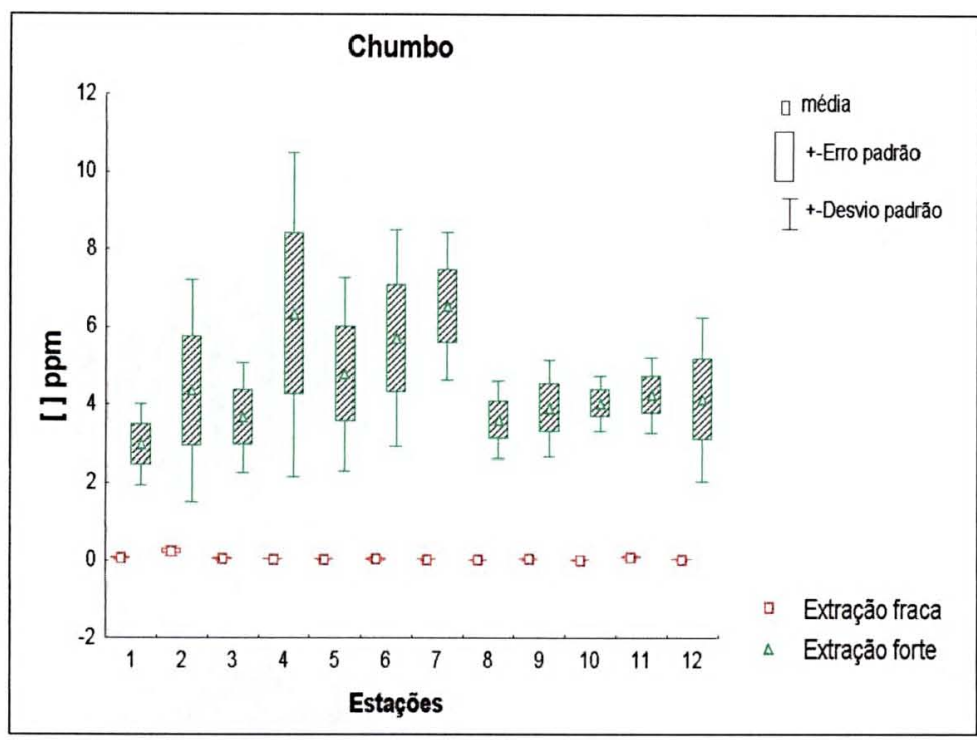

Figura 28 - Variação temporal das concentrações de chumbo nos sedimentos superficiais durante o período investigado.

\subsubsection{Zinco}

Os resultados de zinco para extração forte mostraram comportamento diferenciado no mês de novembro nas estações 2, 5 e 8, ultrapassando o limite crítico de 124 ppm. Para a extração fraca os valores mais elevados foram registrados nas estações 2, 3, 4, 5 e 11, com valores mais altos nos meses de janeiro, maio e agosto (Figura 29). 


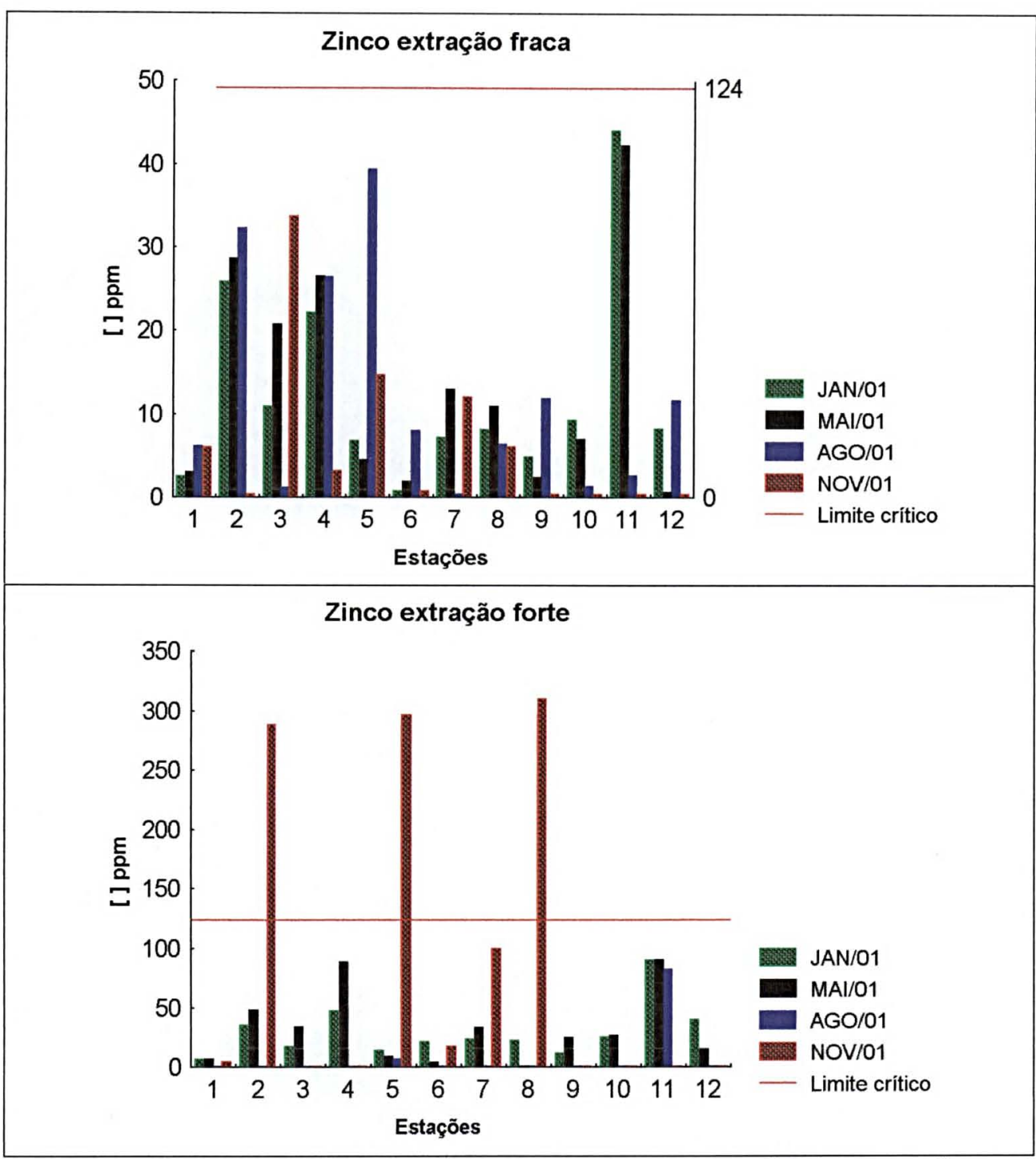

Figura 29 - Concentrações de zinco (ppm) obtidas através de extração total e parcial em amostras de sedimento superficial das 12 estações investigadas. A linha horizontal (em vermelho) representa o limite crítico específico para este metal (124 ppm) adotado na avaliação do grau de contaminação dos sedimentos.

O elevado desvio padrão relativo à extração forte encontrado para o elemento zinco (Figura 30) é explicado pelas elevadas concentrações do mês de novembro, elevando o valor médio das concentrações nas estações 2, 5 e 8. Para a extração fraca a concentração média mais elevada foi registrada na estação 11 (Rio Itiberê), assim como para outros elementos já comentados. 


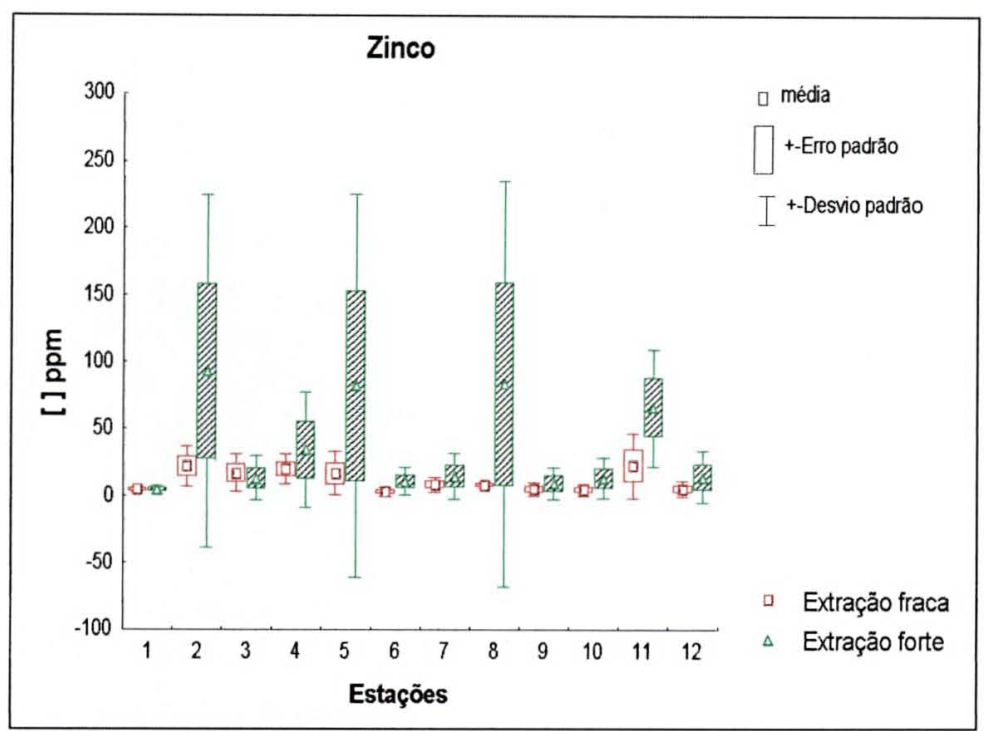

Figura 30. Variação temporal das concentrações de zinco nos sedimentos superficiais.

\subsubsection{Mercúrio}

As concentrações obtidas na extração de mercúrio permaneceram abaixo do limite crítico de 0,130 ppm, com valores mais altos nas estações 3 e 6 no mês de novembro. Estes resultados diferem dos obtidos em janeiro de 2000 pela APPA 1998/1999 os quais estiveram bem acima do limite adotado (Figura 31).

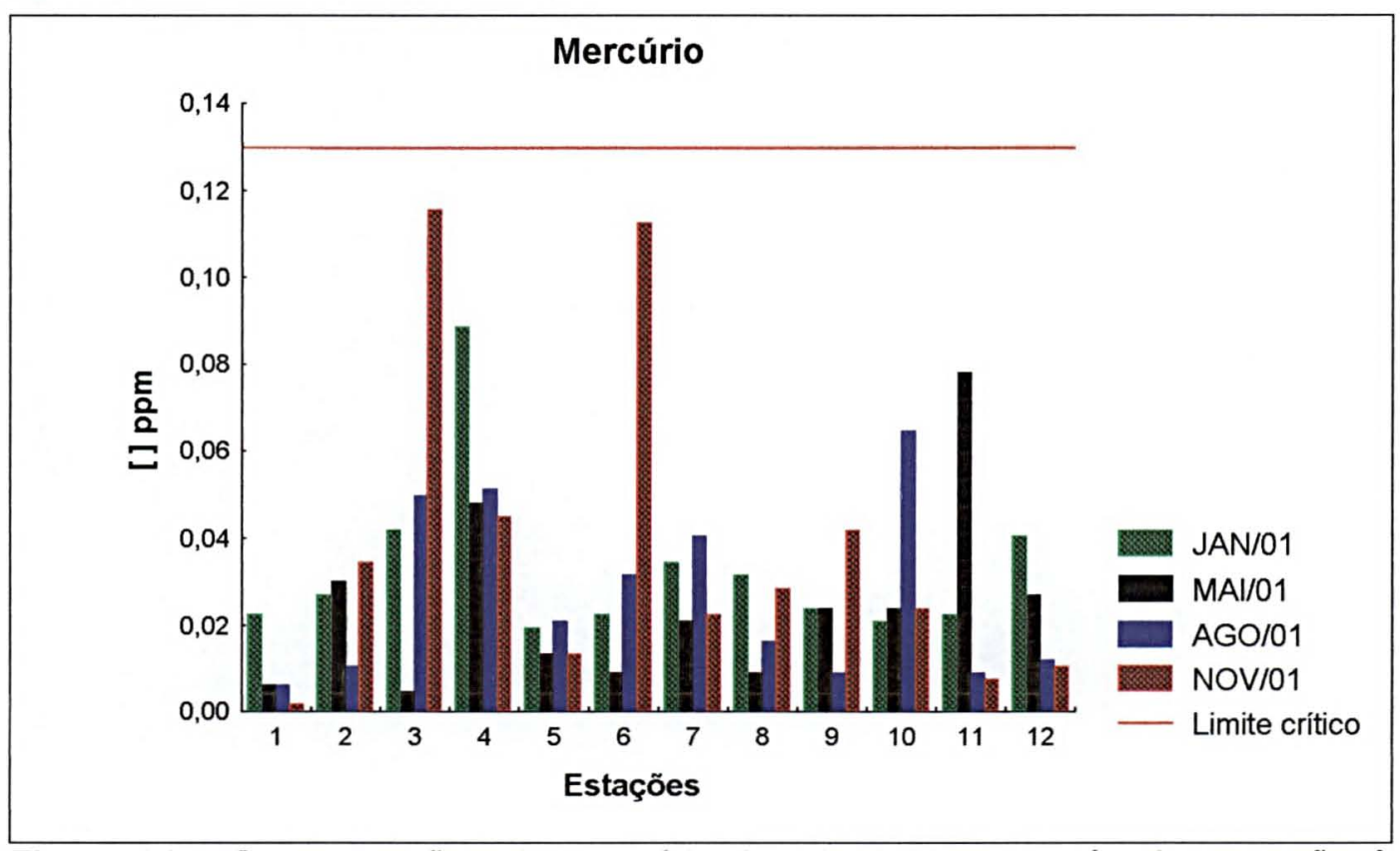

Figura 31 - Concentrações de mercúrio (ppm) obtidos através de extração à vapor frio em amostras de sedimento superficial das 12 estações investigadas. $A$ linha horizontal (em vermelho) representa o limite crítico específico para este metal $(0,13 \mathrm{ppm})$ adotado na avaliação do grau de contaminação dos sedimentos. 
As maiores médias das concentrações de mercúrio encontram-se nas estações 4 e 3 , sendo esta última localizada dentro do mangue localizado ao lado da indústria de fertilizante (Figura 32).

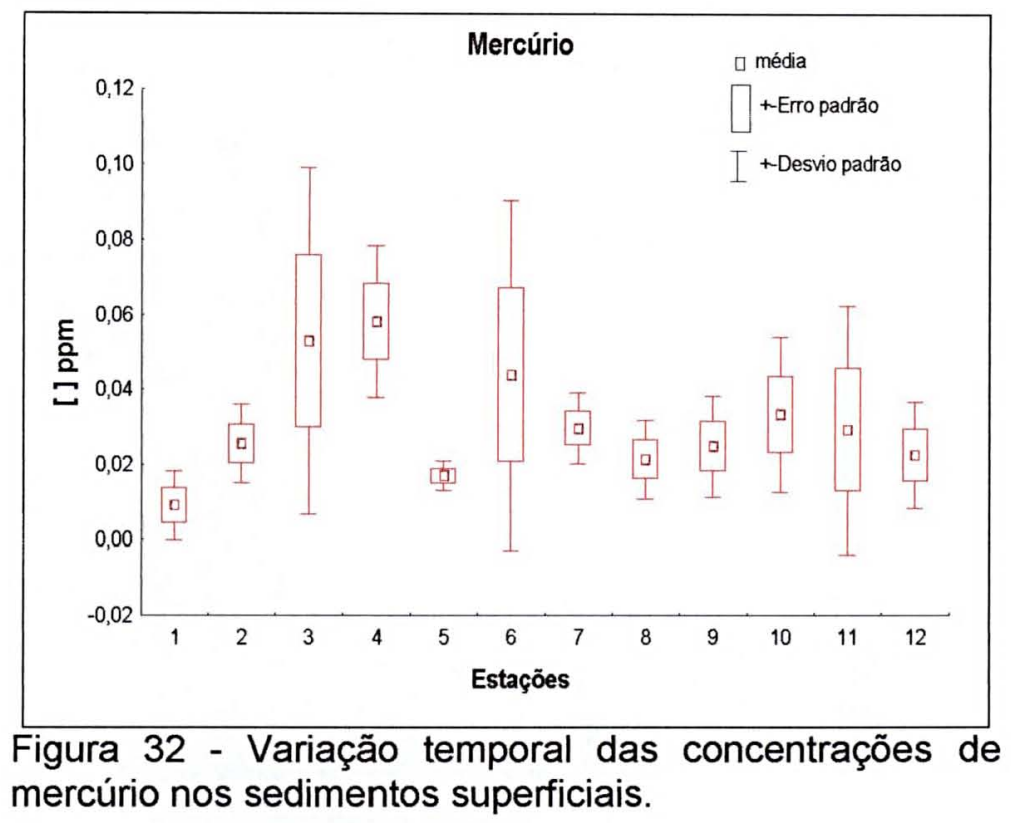

\subsubsection{Carbono orgânico total}

O padrão da distribuição espacial dos teores de carbono orgânico total observado neste estudo demonstram o impacto dos esgotos urbanos na região, pois os pontos 2 e 11, onde foram registradas concentrações mais elevadas, estão situados nas desembocaduras dos rios Anhaia e Itiberê, respectivamente. $O$ ponto 3 está situado dentro de um mangue, o que explica as concentrações elevadas determinadas neste local (Figura 33).

As análises de correlação efetuadas não detectaram relações significativas dos teores de arsênio, níquel e zinco com as concentrações de carbono orgânico total. 


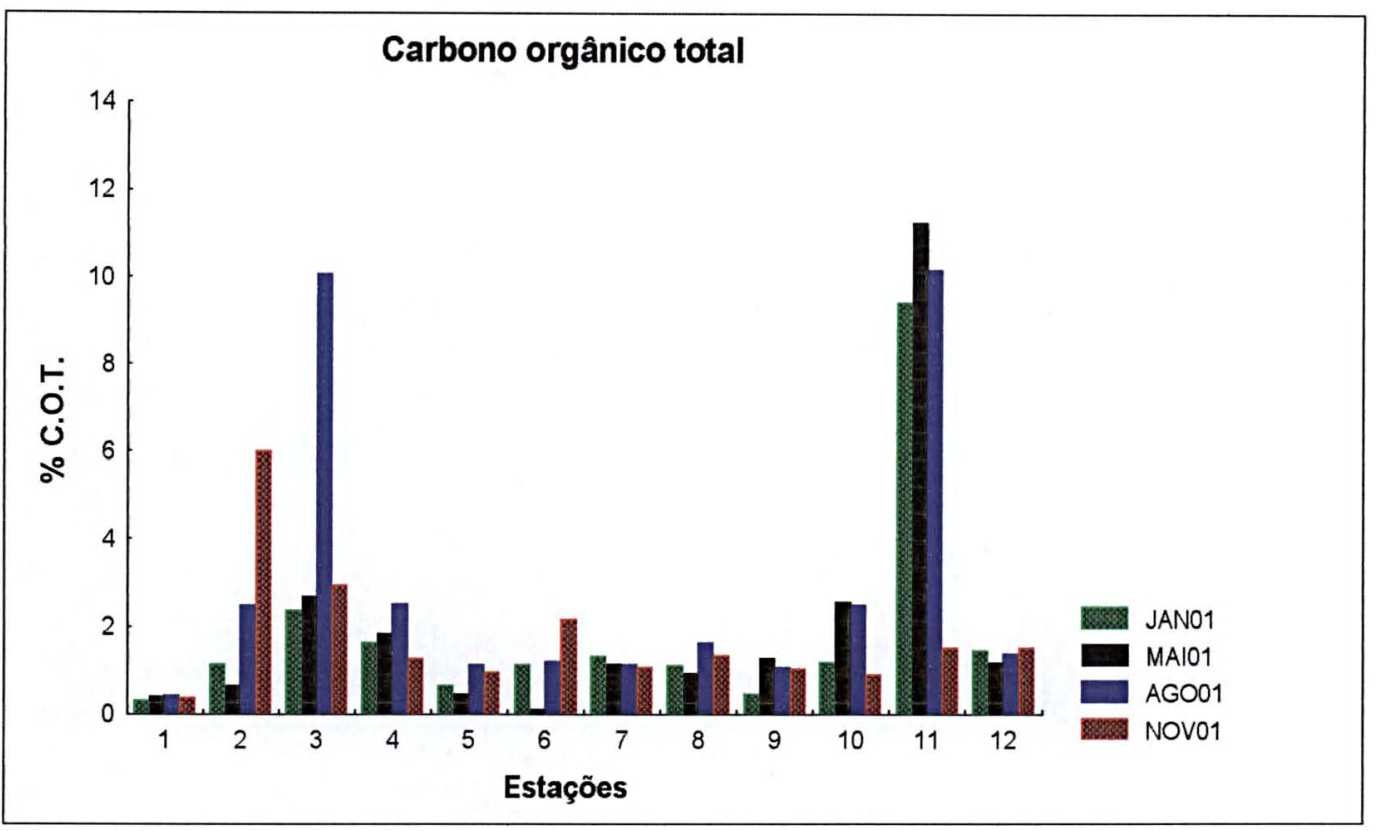

Figura 33 - Valores das concentrações de carbono orgânico total.

\subsubsection{Análise estatística}

Através da análise de agrupamento (Cluster), para as concentrações obtidas pela extração fraca (Figura 34), foi verificado que a estação 12 não ficou agrupada com as demais, isto já era esperado pois esta era a estação controle na segunda etapa deste trabalho. Os dois grupos principais, formados através da análise, não corresponderam com os resultados esperados, apresentando a estação 1, local não contaminado (Rio Emboguaçu), agrupada as demais estações localizadas nas cercanias da industria de fertilizantes. $O$ outro grupo apresenta a estação 3 (mangue) agrupada à estação 8 (industria de fertilizantes). 


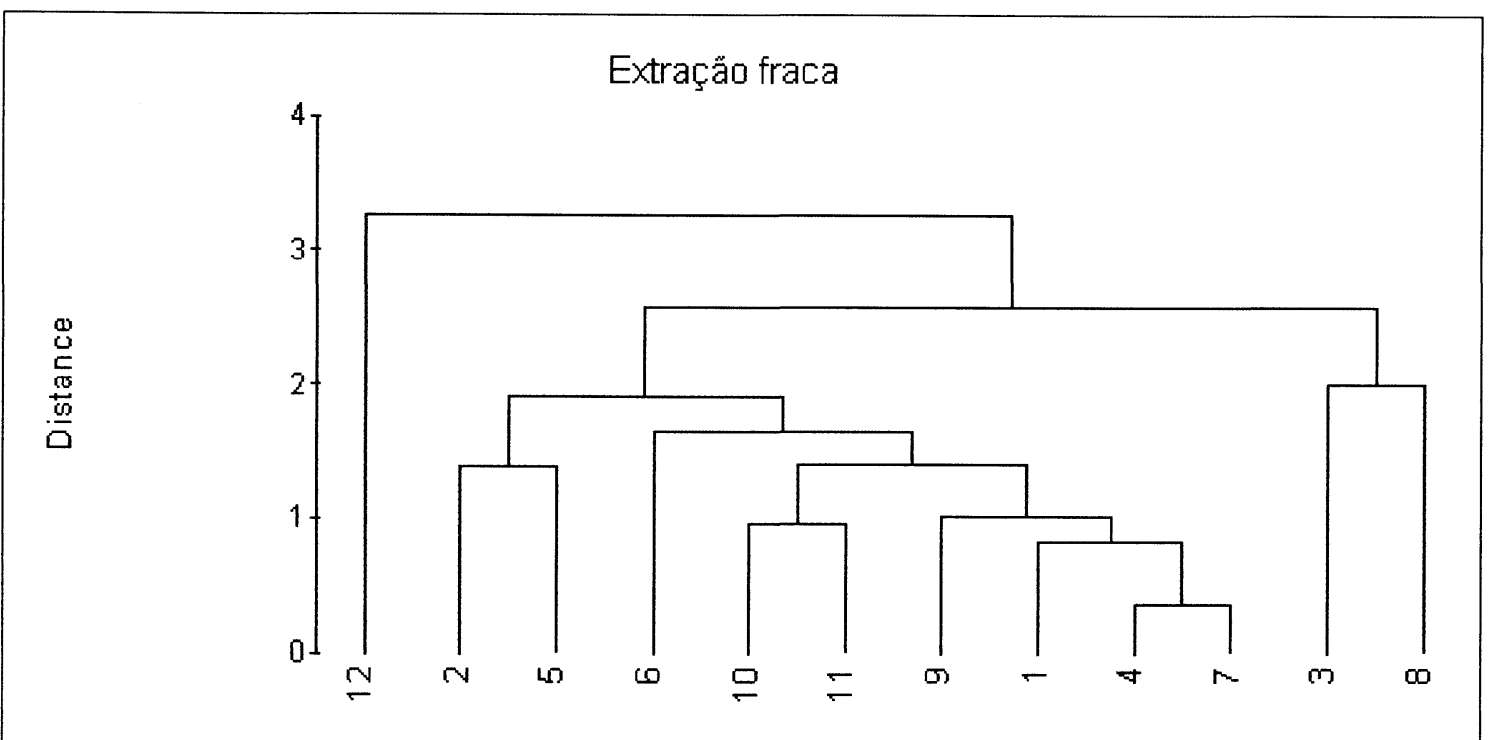

Figura 34 - Análise de agrupamento (Cluster) relativo à extração fraca.

A análise de escalonamento multidimensional (MDS) dos elementos analisados na extração fraca (Figura 35) não demonstrou uma ordenação, por exemplo, de locais menos poluídos para mais poluídos. Apenas confirmou o resultado obtido na análise de agrupamento, onde a estação 12 diferenciou das demais.

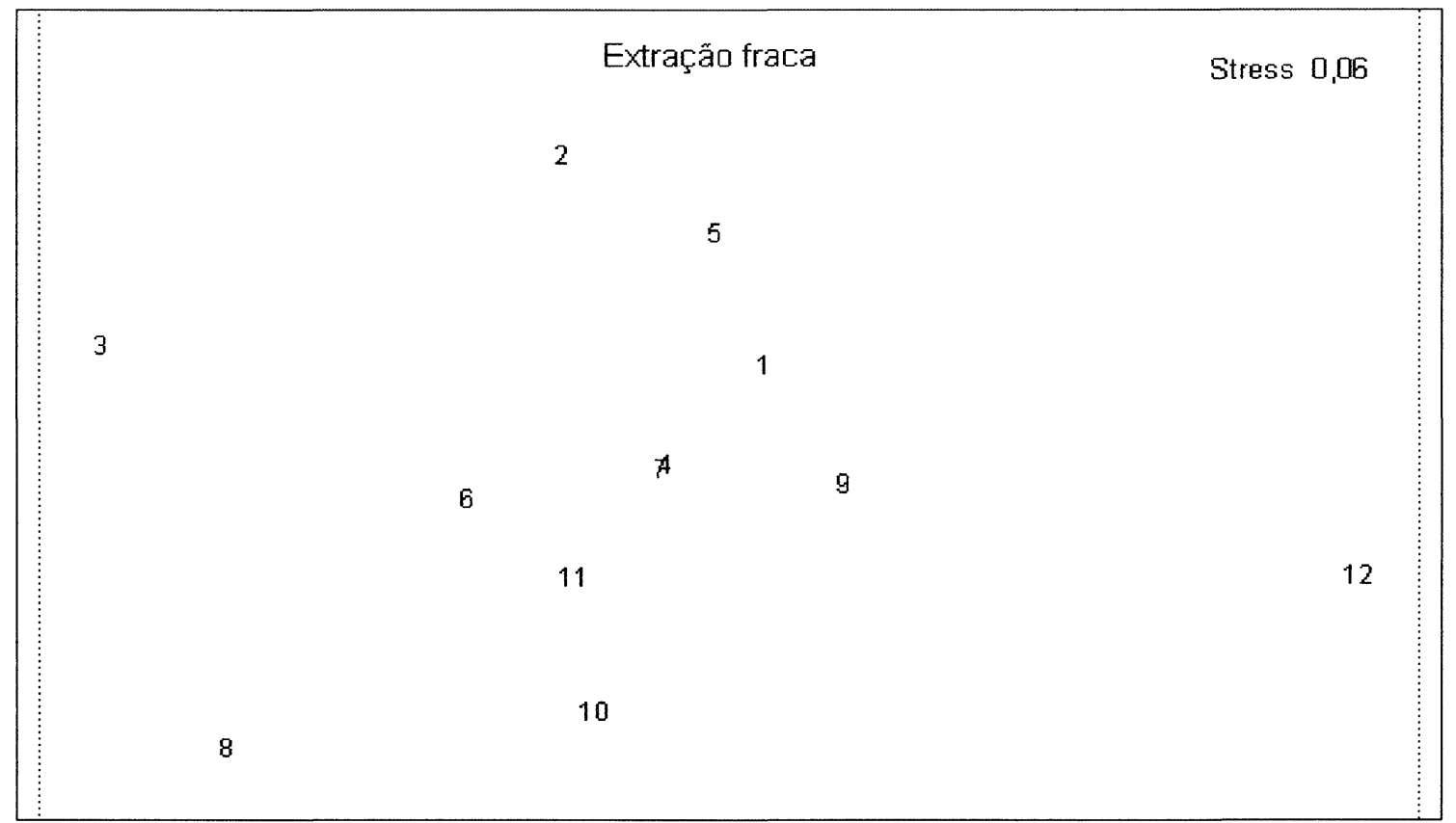

Figura 35 - MDS relativo à extração fraca.

Para as concentrações obtidas pela extração forte a análise de agrupamento (Cluster) (Figura 36) não demonstrou o mesmo agrupamento obtido para a extração fraca, sendo a estação 12 agrupada com as localizadas 
na industria de fertilizante $e$ as dos rios Itiberê e Emboguaçu. $O$ outro grupo formado também não apresentou uma separação das estações, levando em consideração suas localizações.

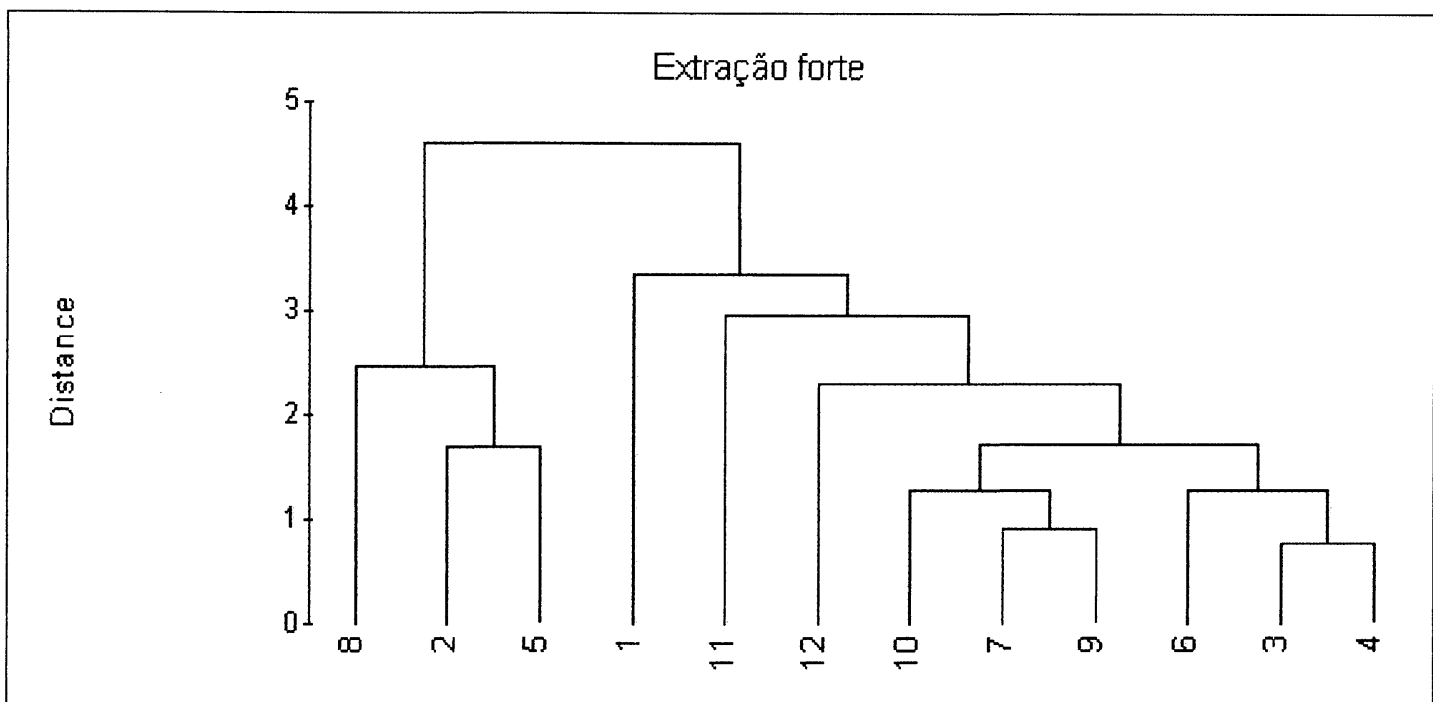

Figura 36 - Análise de agrupamento (Cluster) relativo à extração forte.

Para as concentrações obtidas através da extração forte a análise de escalonamento multidimensional (MDS) (Figura 37) não apresentou uma ordenação das estações. Porém, nota-se o distanciamento das estações 1, 11 e 12, respectivamente, o Rio Emboguaçu, Rio Itiberê e a Baía das Laranjeiras.

Figura 37 - MDS relativo à extração forte. 
5.3 Terceira etapa: Avaliação da qualidade do sedimento na bacia de evolução do porto de Paranaguá.

Os resultados da segunda etapa complementar deste trabalho são apresentados na tabela 10 e na figura 38 e comentados a seguir.

Tabela 10 - Teores para os elementos metálicos investigados expressas em ppm (mg/Kg) e dos limites críticos adotados (Buchman M.F.1999).

\begin{tabular}{cccccccc}
\hline Amostra & $\mathbf{A s}$ & $\mathbf{N i}$ & $\mathbf{Z n}$ & $\mathbf{C d}$ & $\mathbf{P b}$ & $\mathbf{C u}$ & $\mathbf{C r}$ \\
\hline Limites críticos & 7.24 & 15.9 & 124.0 & 0.676 & 30.24 & 18.7 & 52.3 \\
2 & 7,600 & 23,510 & 26.473 & 0.249 & 6.243 & 1.998 & 2.247 \\
6 & 0,890 & 3,210 & 15.422 & 0.000 & 13.432 & 4.228 & 0 \\
7 & 1,250 & 7,330 & 8.697 & 0.000 & 6.709 & 0.745 & 0.497 \\
8 & 1,330 & 5,740 & 6.5 & 0.000 & 6.000 & 1.000 & 0.25 \\
9 & 1,900 & 8,150 & 7.492 & 0.000 & 6.743 & 0.499 & 0.249 \\
10 & 1,950 & 6,570 & 6.743 & 0.000 & 6.993 & 1.248 & 0.499 \\
11 & 1,700 & 7,220 & 7.477 & 0.000 & 7.976 & 1.744 & 0.747 \\
\hline
\end{tabular}




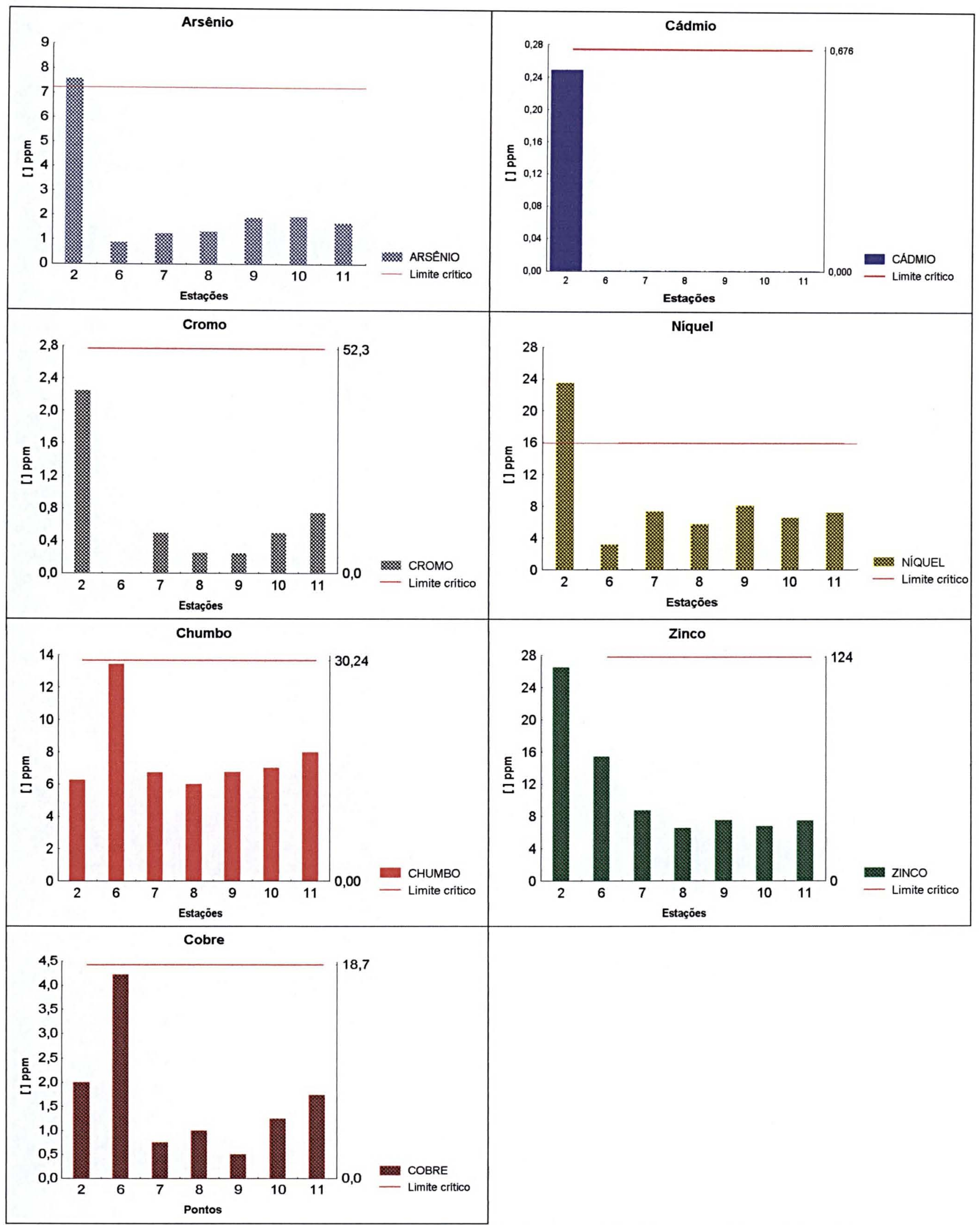

Figura 38 - Concentrações dos elementos metálicos analisados na etapa 2, valores apresentados em $\mathrm{mg} / \mathrm{Kg}(\mathrm{ppm})$, obtidos através de extração fraca em amostras de sedimento superficial das 7 estações investigadas. A linha horizontal (em vermelho) representa o limite crítico específico adotado na avaliação do grau de contaminação dos sedimentos e é representada no eixo à direita, em ppm. 
Com base nas características ambientais do local do empreendimento (existência de indústrias e atividades portuárias importantes, entre outros), e os estudos e dados anteriores, foram selecionados os elementos metálicos Arsênio (As), Cádmio (Cd), Cobre (Cu), Cromo ( $\mathrm{Cr}$ ), Chumbo (Pb), Níquel (Ni) e Zinco (Zn) para a caracterização da grau de contaminação dos sedimentos da região.

Para se dispor de uma base de dados mais consistente visando futuros estudos de controle ambiental e considerando a falta de informações referentes aos metais pesados do sistema estudado, bem como a importância nos processos de contaminação, optou-se pelas determinações com extração fraca (lábeis ou mobilizáveis).

Exceto para o As e $\mathrm{Ni}$, os valores dos elementos metálicos investigados estiveram abaixo dos limites críticos adotados neste trabalho (tabela 10). Isto era esperado uma vez que foram realizadas extrações fracas dos elementos metálicos, porém estes valores são bem próximos dos obtidos em outro trabalho (Kolm et al., 2002) realizado na baía de Paranaguá. Assim, pode-se inferir que as concentrações totais destes elementos ultrapassariam os limites críticos estabelecidos.

As estações 7, 8, 9, 10 e 11 apresentaram as menores concentrações para todos os elementos metálicos analisados (tabela 10). As maiores concentrações dos elementos metálicos na área estudada estão associadas às zonas pouco profundas, estações 2 e 6 , próximas aos efluentes industriais e domésticos. A estação 6 apresentou os maiores valores para os seguintes elementos: $\mathrm{Pb}(13,43 \mathrm{mg} / \mathrm{Kg})$ e $\mathrm{Cu}(1,99 \mathrm{mg} / \mathrm{Kg})$, e a estação 2 para os elementos As $(7,6 \mathrm{mg} / \mathrm{Kg}), \mathrm{Ni}(23,51 \mathrm{mg} / \mathrm{Kg}), \mathrm{Zn}(26,47 \mathrm{mg} / \mathrm{Kg}), \mathrm{Cd}(0,249$ $\mathrm{mg} / \mathrm{Kg})$ e $\mathrm{Cr}(2,247 \mathrm{mg} / \mathrm{Kg})$.

Destaca-se que as concentrações dos elementos As e Ni (Figura 38) apresentaram valores acima do limite crítico, de 7,24 e $15,9 \mathrm{mg} / \mathrm{Kg}$, respectivamente. As concentrações destes elementos, quando comparados com aquelas encontradas por Kolm et al. (2002), mostram que se fossem realizadas extrações fortes, os valores seriam bastante elevados, o que indica um aporte considerável destes elementos na região oeste portuária da cidade de Paranaguá. 


\section{Discussão}

Tendo em vista as características do complexo estuarino, onde coexistem zonas de baixa profundidade com zonas de canais, a discussão dos resultados será realizada considerando, quando necessário, esses segmentos ambientais em separado. Os sedimentos das zonas profundas e rasas apresentam características mineralógicas, granulométricas e geoquímicas específicas. Os fatores reguladores da geoquímica dos sedimentos são fortemente dependentes dos processos físicos atuantes na região. A comparação dos dados pretéritos com os resultados obtidos neste estudo permitiu examinar algumas tendências das modificações ambientais.

\subsection{Elementos metálicos nos sedimentos superficiais}

De todos os elementos analisados no presente estudo, apenas o chumbo não apresentou concentrações acima do limite crítico, enquanto os elementos arsênio, cobre, níquel, zinco, mercúrio, cromo e cádmio apresentaram concentrações acima dos limites críticos. Na Baía de Antonina, foram encontradas concentrações elevadas de mercúrio, cromo, cádmio, arsênio e níquel, enquanto que na Baía de Paranaguá dominaram os elementos cobre, zinco, arsênio e níquel.

\subsubsection{Arsênio}

O elemento arsênio apresentou as maiores concentrações totais, na extração forte, em ambas as baías. Analisando a distribuição deste elemento no eixo L - O do Complexo Estuarino da Baía de Paranaguá observou-se um acréscimo significativo em direção à cidade de Paranaguá (Figura 39), indicando a presença de fontes potenciais de arsênio neste local.

Ambos os processos, antropogênicos e naturais, têm sido estudados para explicar anomalias quanto a altas concentrações de arsênio em sedimentos. CRECELIUS et al. (1975) realizaram estudos com sedimentos marinhos, mostrando que a contaminação por arsênio nesses sedimentos $(50-400 \mathrm{mg} / \mathrm{Kg})$ acompanha altos níveis de antimônio, provenientes de descargas atmosféricas e 
particuladas próximo a uma siderúrgica de cobre. Em contraste, FARMER \& LOVELL (1986) propuseram o enriquecimento natural para explicar altas concentrações de arsênio (acima de $650 \mathrm{mg} / \mathrm{Kg}$ ) em sedimentos superficiais no estuário de Loch Lomond (Escócia), região livre de fontes antropogênicas. Outras investigações também detectaram altas concentrações de arsênio em sedimentos superficiais considerando outros ecossistemas estuarinos e costeiros (Haynes, 2002; Loring, 1995; Shumilin, 2001; Neff, 1996; Belzunce, 2001).

Concentrações de arsênio em sedimentos marinhos e estuarinos não contaminados normalmente variam de 5 a $15 \mathrm{mg} / \mathrm{Kg}$ em peso seco (MOORE \& RAMAMOORTHY, 1984). Entretanto, há dados que mostram que a concentração média de arsênio em sedimentos de oceano profundo é aproximadamente 40 $\mathrm{mg} / \mathrm{Kg}$ (BOSTROM \& VALDES, 1969).

$\mathrm{O}$ arsênio é liberado naturalmente para o ambiente através do intemperismo de rochas ricas em arsênio, arsenopirita em veios de ouro e da atividade vulcânica. Em adição às fontes naturais, o arsênio pode ser liberado para o ambiente como resultado de atividades humanas. Este elemento é usado em pigmentos, para fins medicinais, na fabricação de vidro, e em ligas com chumbo e cobre. Além disso, o arsênio é usado em alguns pesticidas (incluindo herbicidas), em desfoliantes de plantas e em vários preservativos.

Devido às características de bioacumulação e toxicidade do arsênio (BHUMBLA \& KEEFER, 1994; BHATTACHARYA et al., 1997, 2001), os processos biogeoquímicos deste elemento na natureza têm gerado muitos interesses sob 0 ponto de vista da pesquisa ambiental nos últimos anos.

Dentro da faixa do Eh e pH nos compartimentos do solo, o Arsênio ocorre normalmente nos estados oxidados +III e +V (CULLEN \& REIMER, 1989). Arsênio(III), $\mathrm{H}_{3} \mathrm{AsO}_{3}{ }_{3}$ ou $\mathrm{H}_{2} \mathrm{AsO}_{3}^{-}$predominam em condições redutoras. Estas formas são mais tóxicas e mobilizáveis quando comparado com arsênio(V), as formas $\mathrm{H}_{2} \mathrm{AsO}_{4}^{-} \mathrm{e} \mathrm{HAsO}^{2-}{ }_{4}$ prevalecem em condições oxidantes e $\mathrm{pH}>8$ (SADIQ et al., 1983; MASSCHELEYN et al., 1991). 


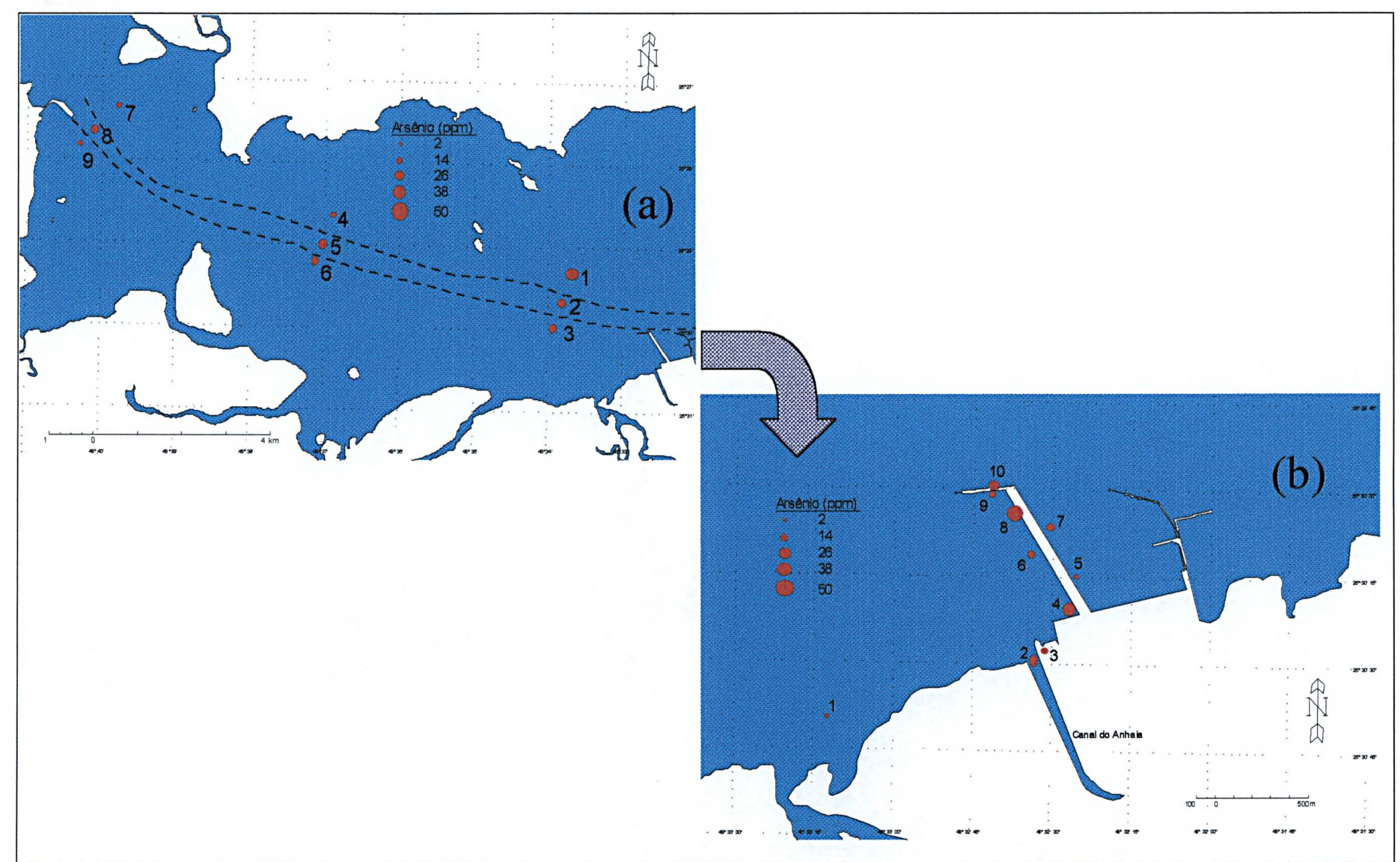

Figura 38 - Distribuição das concentrações de arsênio (ppm) relativo à extração forte na Baía de Antonina e nas cercanias da industria de fertilizantes local. 
Um aumento na concentração de arsênio pode ser observado com o aumento no teor de argila dos solos contaminados (GALBA \& POLACEK, 1973). A sorção preferencial do arsênio(V) em argilo minerais como caolinita, ilita e montmorilonita ocorrem em pH 2,0 - 7,9. Para arsênio(III) ocorre sorção preferencialmente entre $\mathrm{pH} 8-10$ (MANNING \& GOLDBERG, 1997). O comportamento geoquímico do arsênio(V) e fósforo são similares e são, ambos, adsorvidos aos óxidos de alumínio, ferrro e, em circunstâncias específicas, com manganês (MANNING \& GOLDBERG, 1996).

Segundo MOORE et al. (1988), o arsênio é, na sua maior parte, dissolvido e mobilizado a partir dos sedimentos marinhos nas interfaces redox e durante transições no potencial redox, podendo sofrer aumento ou decréscimo em sua concentração. Durante decréscimos de potencial redox, arsênio é liberado na água intersticial pela dissolução de óxidos de ferro e manganês. A água rica em arsênio pode ser misturada com a coluna d'água por ressuspensão e transporte sedimentar ou por bioturbação (MASSCHELEYN et al., 1991; RIEDEL et al., 1989).

No Complexo Estuarino da Baía de Paranaguá, a concentração de arsênio passível de extração em solução de ácido diluído, ou seja, a fração de maior disponibilidade biológica do elemento arsênio foi verificada apenas na baía de Paranaguá e apresentou suas maiores concentrações nas regiões oeste e leste do porto de Paranaguá, entre o final do cais oeste e o píer da Petrobrás/Catallini (Figura 2). Estas concentrações superaram o limite crítico adotado, indicando que grande quantidade deste elemento pode ser encontrada nos organismos e ser incorporado à cadeia alimentar, podendo apresentar impactos ambientais e sociais negativos.

O comportamento geoquímico dos elementos arsênio e fósforo são semelhantes. Shumilin et al. (2001), relacionaram as altas concentrações de arsênio em sedimentos com a presença de material fosfatado, provenientes do intemperismo de rochas enriquecidas em fósforo. No caso do Complexo Estuarino da Baía de Paranaguá este material fosfatado, resultante de intemperismo, pode 
ocorrer na composição mineralógica do sedimento. Porém, o aumento do teor de Arsênio próximo a cidade de Paranaguá pode estar relacionado com rochas fosfatadas utilizadas na produção de fertilizantes pela indústria local, entrando no ambiente pelo despejo de efluente resultante deste processo.

Kolm et al. (2002) realizaram análises de arsênio em fígado de Cathorops spixii (Ariidae), provenientes da Baía de Antonina. Os resultados mostraram que os valores mais elevados foram detectados na fase de pré-dragagem do canal de acesso ao Porto de Antonina e a concentração mais elevada foi de $518,69 \mu \mathrm{g} / \mathrm{Kg}$. Isto indica que uma quantidade ainda desconhecida deste elemento está na forma biodisponível, pois os processos de bioacumulação e biomagnificação já foram detectados neste ambiente.

\subsubsection{Cobre}

A única região que apresentou concentração total acima do limite crítico foi o ponto de amostragem localizado no rio Itiberê, sendo que as demais localidades, tanto na região mais interna do estuário (Antonina) quanto nas cercanias do porto de Paranaguá, as concentrações ficaram sempre abaixo deste limite (Figura 40). Isto indica que o rio Itiberê, o qual recebe efluentes urbanos, pode ser uma fonte potencial deste elemento para o Complexo Estuarino da Baía de Paranaguá. Entretanto, apesar da concentração total (extração forte) ter sido elevada (Figura 41), a fração associada à biodisponibilidade foi baixa nestes sedimentos. Isto significa que o cobre está sendo introduzido no ambiente e, como resultado de processos biogeoquímicos locais, este elemento encontra-se predominante em forma não biodisponível. 


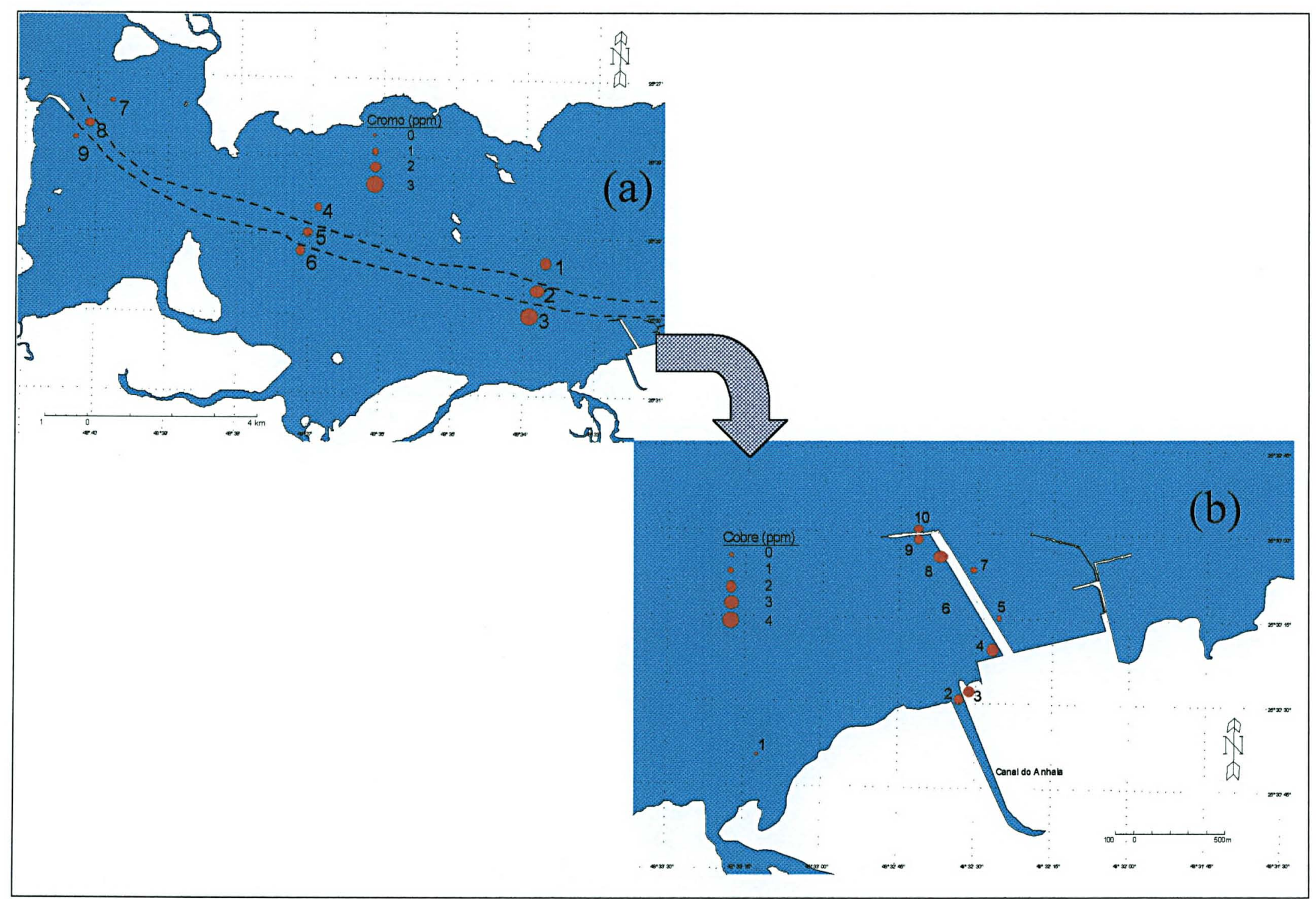

Figura 39 - Distribuição das concentrações de cobre (ppm) relativo à extração fraca no canal de acesso à Baía de Antonina (a) e nas cercanias da industria de fertilizantes local (b). 


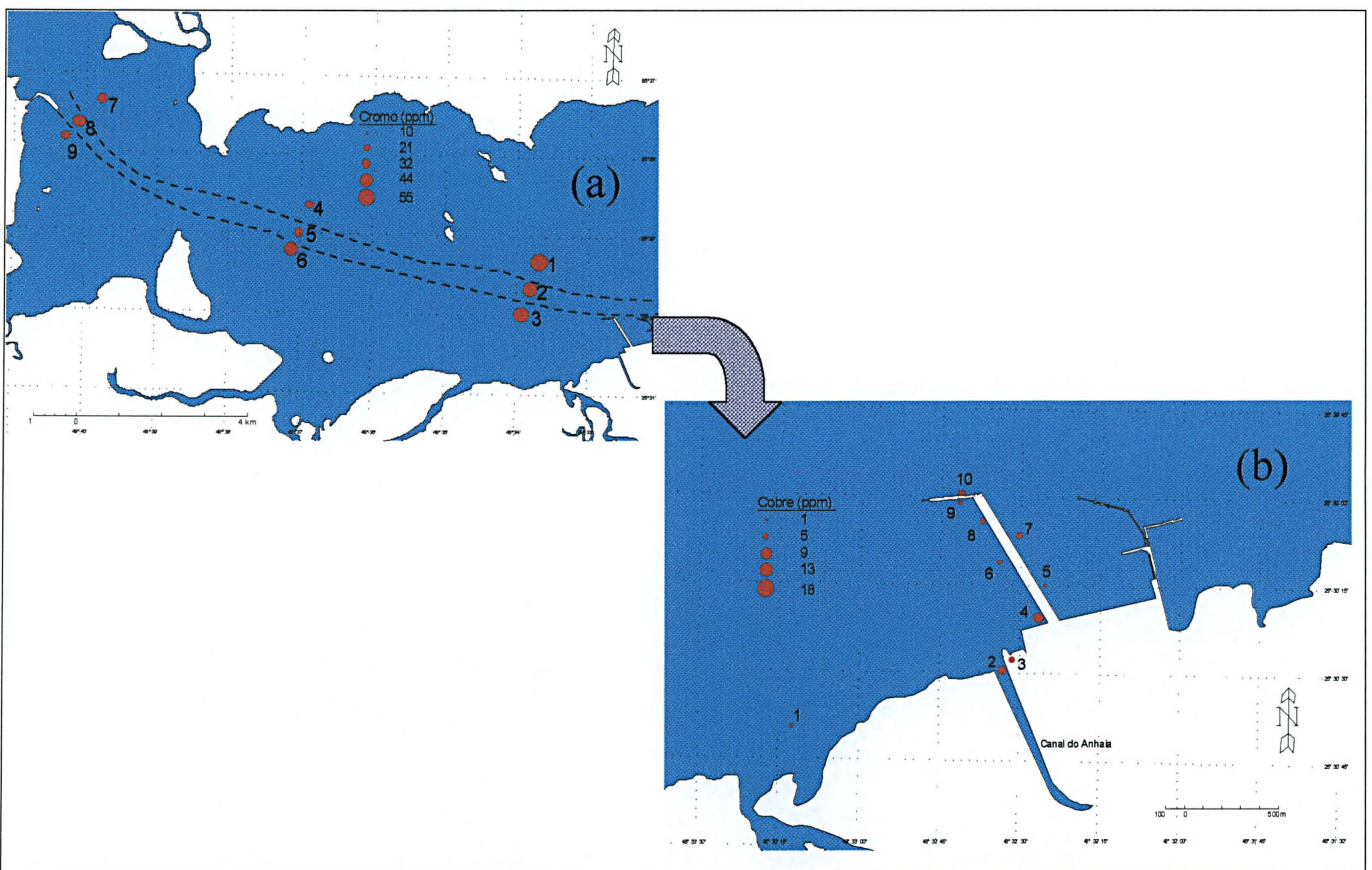

Figura 40 - Distribuição das concentrações de cobre $(\mathrm{ppm})$ relativo à extração forte no canal de acesso à Baía de Antonina (a) e nas cercanias da industria de fertilizantes local (b). 
Chon-Lin Lee, et al. (1998) relacionaram contaminação por cobre aos efluentes urbanos e atividades industriais, sendo o estudo realizado em local de densa população. Belzunce, et al. (2001), em estudo realizado no estuário do Rio Nervión (Espanha), analizou cobre na fração sedimentar $<63 \mu \mathrm{m}$ e encontrou concentrações bastante elevadas $(>500 \mathrm{mg} / \mathrm{Kg}$ ). Estas altas concentrações também foram atribuídas às atividades industriais do local.

O cobre é um elemento metálico comum em rochas e minerais da crosta. Fontes naturais de cobre nos ambientes aquáticos incluem o intemperismo e a dissolução de minerais que contém cobre e sulfetos de cobre. Potenciais fontes antropogênicas de cobre incluem a corrosão de tubulações metálicas e de cobre por águas ácidas, o uso de compostos de cobre como algicidas aquáticos, efluentes de plantas de tratamento de esgotos, drenagem de água subterrânea contaminada, usos agrícolas de compostos contendo cobre como fungicidas e pesticidas, além de precipitações atmosféricas.

$O$ cobre pode existir em diferentes estados de oxidação nos ecossistemas aquáticos, sendo os mais comuns o cobre(I) e cobre(II). Na água, o cobre pode formar associações com a matéria orgânica e precipitados de hidróxidos, fosfatos e sulfetos. A formação destes complexos tende a facilitar o transporte para os sedimentos. Sob condições redox e de $\mathrm{pH}$ normais, o cobre tende a estar presente nos sedimentos na forma de complexos orgânicos, carbonatos e, pode ainda sofrer co-precipitação com óxidos de ferro e de manganês (Jaagumagi, 1990).

O cobre é um micronutriente essencial e, portanto possui rotas metabólicas definidas para sua entrada nas células. É prontamente acumulado nos organismos, especialmente nas plantas (Lombardi et al., 2002). Como biocida, está associado com toxicidade aguda e crônica e diversos efeitos sub-letais nos organismos aquáticos (CCREM, 1987; MacDonald, 1994).

$\mathrm{Na}$ Baía de Antonina, Kolm et al. (2002) analisaram tecidos de Cassostrea sp. e fígado de Cathorops spixii (Ariidae) e indicaram que as ostras coletadas depois da dragagem apresentaram valores mais elevados de cobre $(10,95 \mathrm{mg} / \mathrm{Kg})$, o que pode estar associado a um aumento na concentração por efeitos diretos das atividades de dragagem. Altas concentrações de cobre foram encontradas no 
sedimento, coincidindo com os resultados de Kolm et al. (2002), cujo estudo foi realizado nas mesmas estações onde foram analisados os tecidos de Cassostrea sp. mencionado acima.

\subsubsection{Níquel}

O níquel apresentou concentrações totais relativamente constantes e acima do limite crítico ao longo de todo o eixo $L-O$ do complexo estuarino em quase todas as estações (Figura 42) e, assim como o arsênio, sua fração associada à biodisponibilidade foi verificada apenas na Baía de Paranaguá, apresentando, valores sempre abaixo do limite crítico. Isto indica que frações de mais forte associação com os compostos do sedimento dominam o estado geoquímico deste elemento.

As concentrações totais mostraram a influência de fontes potenciais de efluentes domésticos e industriais nas cercanias do porto de Paranaguá. Estas fontes estão situadas entre o cais do porto e o pier da Petrobrás/Catallini e na região mais externa do estuário no Rio Itiberê, onde também se verificaram concentrações elevadas de cobre. Nesta localidade, entre o cais do porto e o pier da Petrobrás/Catallini foram detectadas concentrações de níquel que se associam com a disponibilidade biológica. Este resultado sugere que o níquel é introduzido no sistema pelas fontes acima mencionadas.

O canal do Anhaia (Figura 2) também pode ser considerado como uma fonte potencial de níquel, apesar das concentrações totais terem sido baixas dentro do canal. Entretanto, à sua frente foram encontrados valores acima do limite crítico. Estes valores reduzidos do canal do Anhaia podem ser explicados pelo baixo valor de potencial de seu sedimento rico em matéria orgânica e com uma qualidade de água pobre em oxigênio (Kolm, et al., 2002), desfavorecendo a sorção e co-precipitação do níquel e também de outros elementos metálicos. 


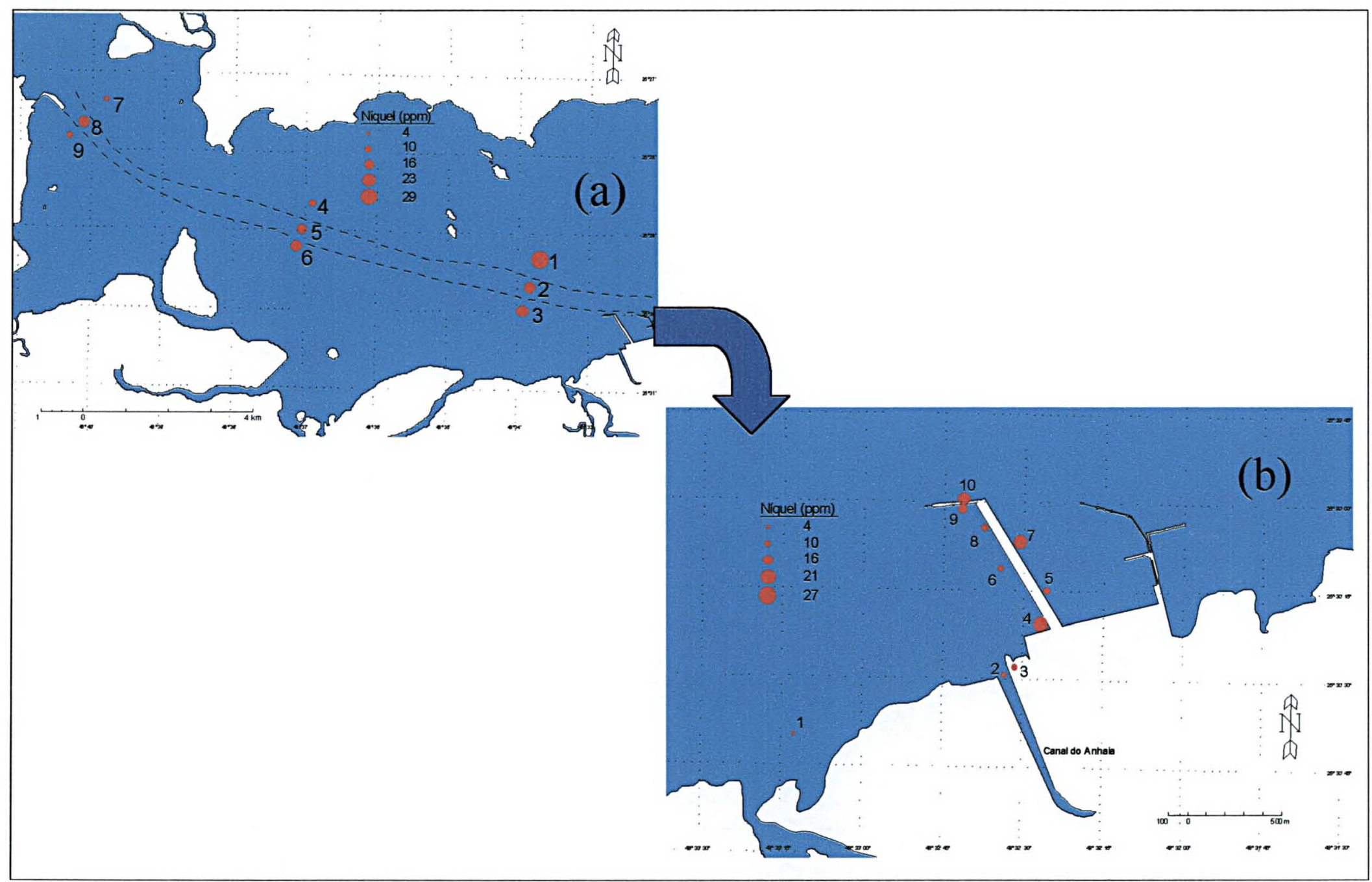

Figura 41 - Distribuição das concentrações de níquel $(\mathrm{ppm})$ relativa à extração forte no canal de acesso à Baía de Antonina (a) e nas cercanias da indústria de fertilizantes local (b). 
Níquel é usado primariamente na fabricação de aço inoxidável, ligas de níquel e outras ligas metálicas, catalisador em processos industriais e na refinação do petróleo. As fontes antropogênicas mais importantes de níquel incluem a combustão de combustíveis fósseis, a mineração de minérios de níquel, atividades de fundição e refinação e industrias eletrônicas.

Nos ecossistemas aquáticos, o níquel ocorre principalmente como níquel(II). O níquel pode ser depositado nos sedimentos em decorrência da coprecipitação com óxidos de ferro e de manganês e sorção com a matéria orgânica. Sob condições anaeróbicas, o níquel também forma complexos insolúveis com sulfetos (Jaagumagi, 1990).

A exposição dos organismos aquáticos a sedimentos contaminados por níquel, pode resultar em uma variedade de efeitos adversos, incluindo mortalidade e redução no crescimento. Embora a bioconcentração tenha sido observada em organismos de vários grupos taxonômicos, a biomagnificação não constitui um fato preocupante nesses ambientes (CCREM, 1987).

\subsubsection{Zinco}

Zinco foi analisado apenas na baía de Paranaguá, pois as concentrações na Baía de Antonina foram baixas.

$\mathrm{Na}$ Baía de Paranaguá, concentrações totais de zinco acima do limite crítico, foram detectadas somente no mês de novembro no canal do Anhaia e na área de influência de sua desembocadura. Apesar de ter sido detectado aumento na concentração total de zinco no mês de novembro, a concentração associada à fração biodisponível permaneceu a mesma durante o período. Isto sugere que o zinco associa-se de maneira mais forte com outros elementos, partículas e compostos no sedimento.

Dados da literatura mostram que a concentração de zinco sofre variações e em alguns ecossistemas estuarinos apresentam concentrações bastante elevadas. $\mathrm{Na}$ maioria dos casos são correlacionadas com atividade industrial (Chon-Lin Lee et al., 1998; Belzunce, et al., 2001; Haynes et al., 2002). 
As frações associadas à biodisponibilidade de zinco, juntamente com a de outros metais comentados anteriormente, demonstraram a influência de fontes potenciais de contaminação como o canal do Anhaia e o Rio Itiberê. Sob condições redutoras, o zinco permanece aprisionado nos sedimentos na forma de sulfetos insolúveis, o que pode explicar sua presença nos sedimentos do canal do Anhaia, enquanto outros elementos metálicos só ocorrem após a desembocadura deste canal.

O zinco é usado, principalmente, em películas para proteger ferro e aço em ligas, em baterias secas e em construções. As principais fontes de zinco para os ambientes aquáticos incluem efluentes de esgotos municipais, atividades de mineração, fundição e refinação de zinco, combustão de madeira, incineração de lixo, produção de ferro e de aço, e outras emissões atmosféricas. Nos ecossistemas aquáticos, o zinco ocorre primariamente como $\mathrm{Zn}(\mathrm{II})$, mas pode formar também compostos orgânicos de zinco. $O$ zinco é um micronutriente essencial e a sua incorporação parece ser independente das concentrações ambientais (MacDonald, 1994). O zinco pode bioacumular em alguns organismos, mas não há evidências de magnificação biológica (Jaagumagi, 1990).

\subsubsection{Mercúrio}

As concentrações de mercúrio apresentaram um decréscimo em direção à região mais externa do complexo estuarino, apresentando concentrações elevadas apenas na baía de Antonina (Figura 43). Ainda não há um levantamento das fontes potenciais de $\mathrm{Hg}$ na região, o que dificulta a interpretação e discussão dos resusltados. A ocorrência de minerações de ouro na Serra do Mar, nessa região, durante o século passado é uma das possíveis fontes potenciais para 0 incremento deste elemento.

Em estudos anteriores (APPA, 1998/1999) mercúrio foi detectado na baía de Paranaguá em baixas concentrações. No presente estudo estas concentrações foram confirmadas. 


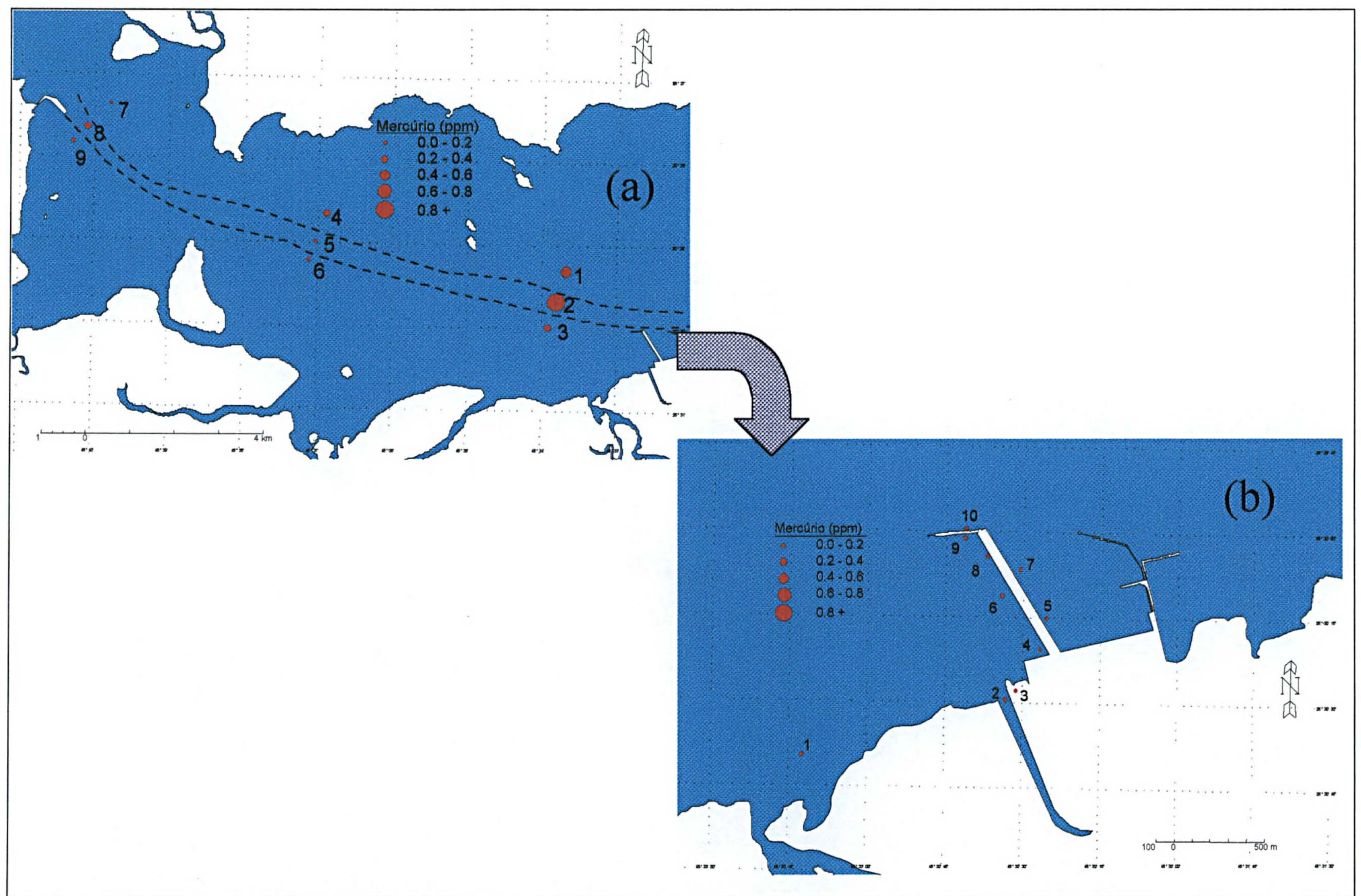

Figura 42 - Distribuição das concentrações de mercúrio (ppm) no canal de acesso à Baía de Antonina (a) e nas cercanias da industria de fertilizantes local (b). 
Kolm, et al. (2002) chamou a atenção para o elemento mercúrio na Baía de Antonina, que nas campanhas de coleta apresentou-se próximo ao limite máximo de tolerância $(487,82 \mu \mathrm{g} / \mathrm{Kg}$ ) nos organismos analisados (Cassostrea sp. e Cathorops spixii (Ariidae)). Observaram também um acúmulo das concentrações deste elemento nos organismos nas campanhas de pós-dragagem. Isto sugere que tal processo pode aumentar a biodisponibilidade do mercúrio para a biota.

O mercúrio é altamente tóxico para a biota, sendo o metil-mercúrio a forma mais tóxica desta substância. O mercúrio tem o potencial de acumular em altos níveis nos organismos aquáticos (CCREM, 1987).

O mercúrio é um elemento traço que ocorre em minerais de sulfeto. $O$ mercúrio é usado, principalmente, na produção de cloreto, soda cáustica na indústria de tintas, de papel, para equipamentos elétricos, em compostos medicinais e em termômetros. Fontes antropogênicas para os ecossistemas aquáticos incluem a incineração de lixo, combustão de carvão, tintas, mineração (principalmente de ouro) e fundição e indústria química.

Nos ecossistemas aquáticos, o mercúrio é geralmente sorvido ou complexado na matéria orgânica. Nos sistemas naturais, o mercúrio pode existir em três estados de oxidação, incluindo o mercúrio elemental, mercúrio(l) e mercúrio(II). Ambos mercúrio(I) e mercúrio(II) podem sofrer o processo de metilação por intermédio de microorganismos sob condições aeróbicas e anaeróbicas. Nos sedimentos o mercúrio tende a formar associações com a matéria orgânica. Sob condições anaeróbicas o mercúrio pode formar sulfetos insolúveis (Jaagumagi, 1990).

\subsubsection{Cromo}

As concentrações totais de cromo, da mesma forma que o mercúrio, mostraram um decréscimo em direção a região externa do complexo estuarino, com concentrações elevadas na baía de Antonina. Na baía de Paranaguá, nota-se a influência da região do canal do Anhaia e do Rio Itiberê, locais onde existe a maior concentração deste elemento (Figura 44). As frações de maior associação com a biodisponibilidade foram detectadas em concentrações elevadas na baía de 
Paranaguá (Figura 45), ao contrário das concentrações totais, o que indica um aporte deste elemento próximo à cidade de Paranaguá. Provavelmente, ocorre uma mistura de águas das baías de Paranaguá e das Laranjeiras, pois a concentração biodisponível mais elevada foi registrada na baía das Laranjeiras, fato também ocorrido com o elemento arsênio.

O cromo é um elemento traço metálico amplamente utilizado em processos industriais. Compostos de cromo hexavalente são usados na indústria metalúrgica para a produção de ligas de cromo e de metais cromados. Além disso estes compostos também são utilizados na indústria química, na produção de tintas, corantes, explosivos, cerâmica, papel e em curtumes de couro. Sais de cromo trivalente são usados na indústria têxtil, na indústria de cerâmicas e vidros, e de fotografia.

Nos ecossistemas aquáticos, o cromo está presente principalmente como cromo(III) e cromo (VI). O cromo(VI) é relativamente solúvel e não tende a sorver na matéria orgânica. Sob condições anaeróbicas, o cromo(VI) pode ser reduzido a cromo(III). Em contraste com o cromo(VI), o cromo(III) sofre prontamente sorção em particulados orgânicos e co-precipita com óxidos e hidróxidos de ferro e manganês. Sob condições anóxicas, o cromo também pode formar sulfetos insolúveis.

Os efeitos biológicos adversos associados com a exposição ao cromo incluem mortalidade e redução no crescimento, sendo as plantas mais vulneráveis que os peixes (CCREM, 1987). O cromo(VI) é mais prontamente acumulado do que o cromo(III) e é considerado como a forma mais tóxica (Jaagumagi, 1990). 


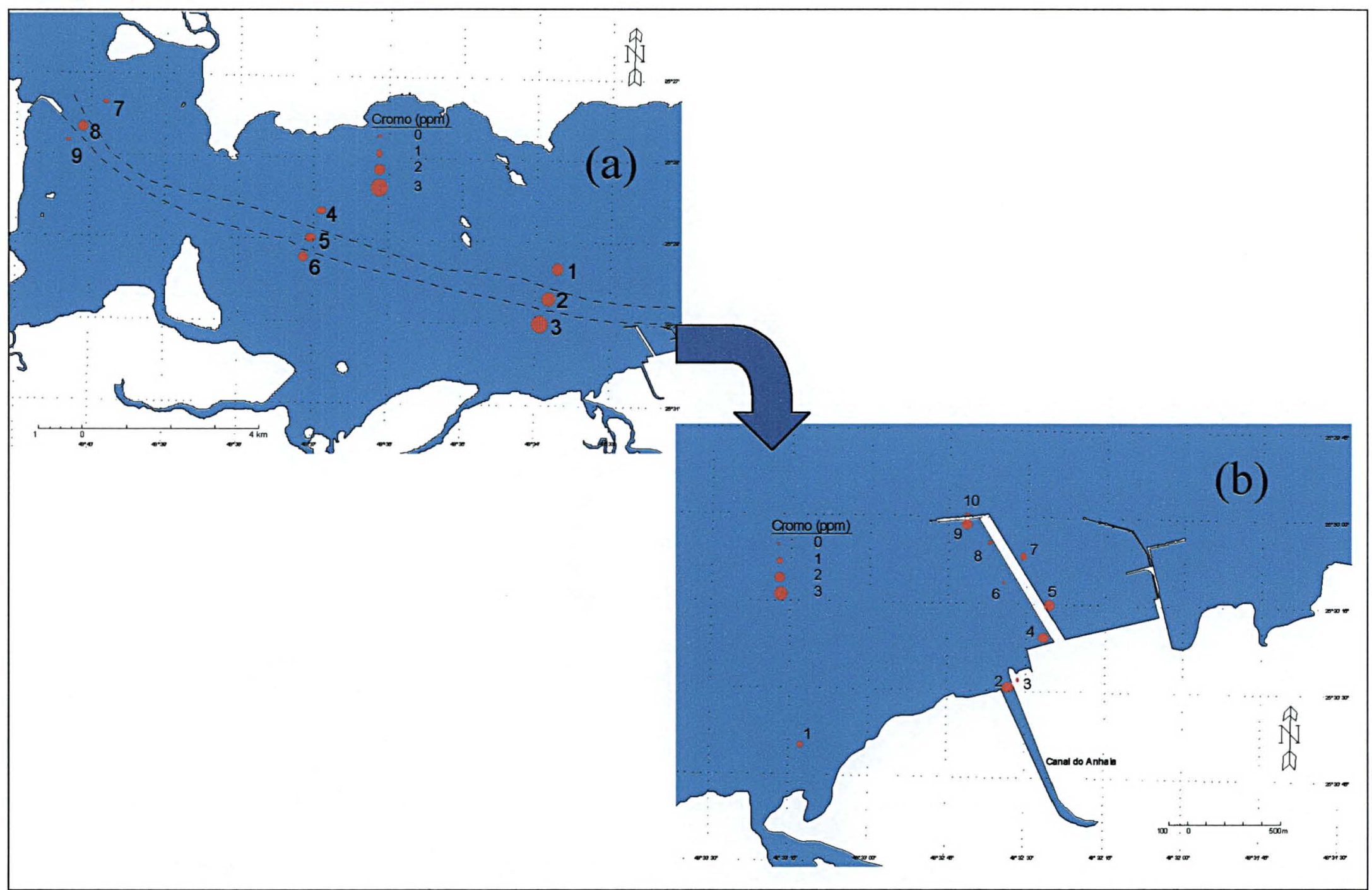

Figura 43 - Distribuição das concentrações de cromo $(\mathrm{ppm})$ relativa à extração fraca no canal de acesso à Baía de Antonina (a) e nas cercanias da indústria de fertilizantes local (b). 


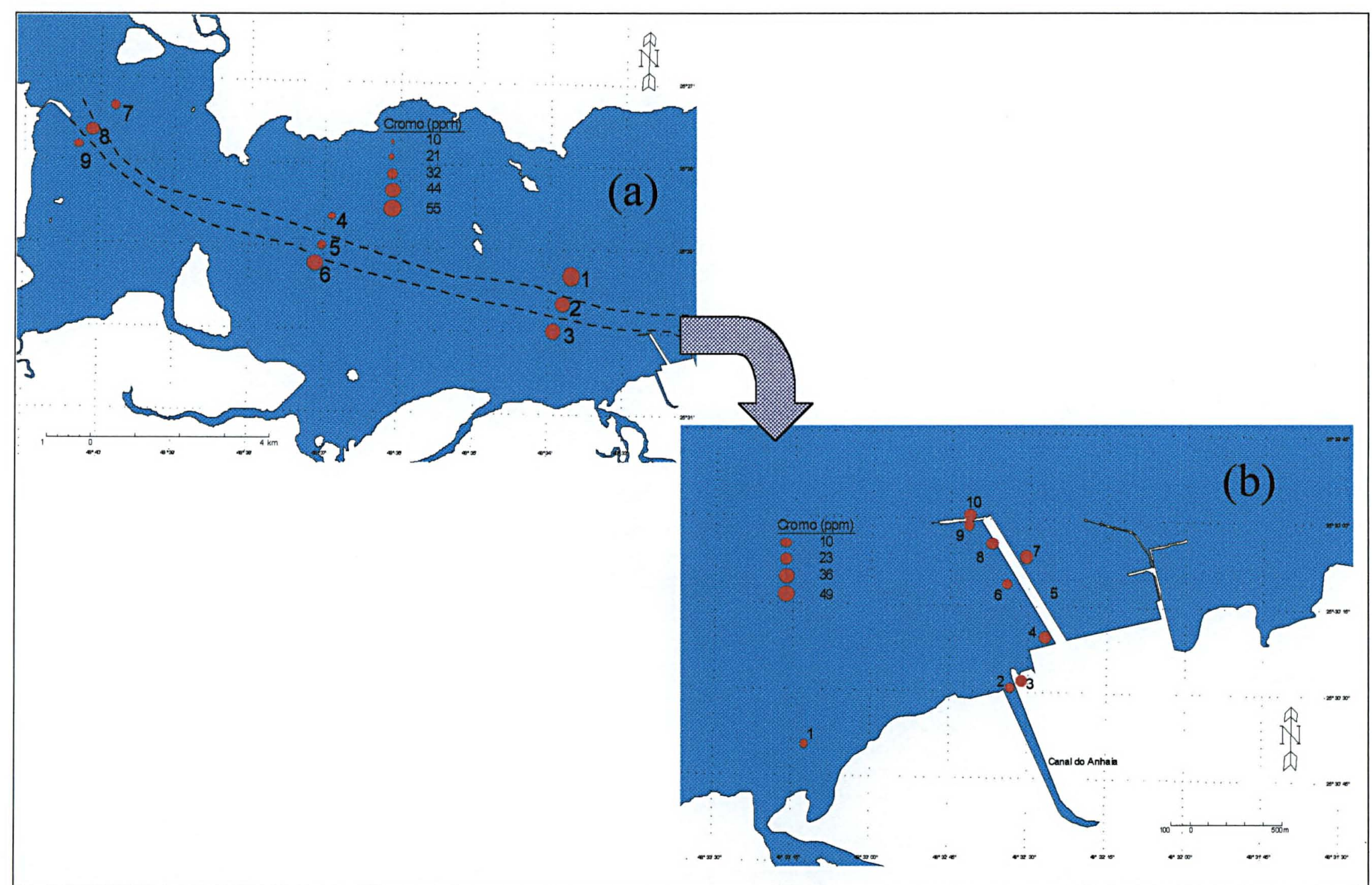

Figura 44 - Distribuição das concentrações de cromo $(\mathrm{ppm})$ relativa à extração forte no canal de acesso à Baía de Antonina (a) e nas cercanias da indústria de fertilizantes local (b). 


\subsubsection{Cádmio}

Assim como o cromo e o mercúrio as concentrações totais de cádmio apresentaram um decréscimo em direção à parte externa do complexo estuarino, com concentrações elevadas na baía de Antonina (Figura 46). Cádmio solubilizado através da extração fraca apresentou maiores concentrações na baía de Paranaguá do que na Baía de Antonina, isto indica que a fração do cádmio que mais se aproxima da fração disponível é maior próximo à cidade de Paranaguá. Isto possibilita a dizer que existem fontes deste elemento nessa localidade.

Comparando os resultados do presente estudo com aqueles obtidos por APPA (1998/1999), nota-se uma variação nas concentrações de cádmio. Em situações onde os resultados da APPA (extração forte) eram bastante elevados, ultrapassando até mesmo o limite crítico, no presente trabalho foram encontrados valores baixos.

O cádmio é utilizado em uma grande variedade de processos, incluindo a fabricação de pigmentos, baterias, ítens de produtos fotográficos, elétricos, cerâmicas, alguns biocidas, e em estabilizadores de plásticos. Além disso o cádmio pode estar presente em rochas fosfatadas usadas para fertilizantes. As principais fontes antropogênicas de cádmio são mineração, indústrias envolvidas na fabricação de ligas, tintas, baterias, plásticos, produtos agrícolas, fertilizantes e pesticidas, além da queima de combustíveis fósseis (CCREM, 1987)

$\mathrm{Na}$ água superficial, o cádmio ocorre geralmente na forma de cádmio(II), como constituinte de compostos inorgânicos (sulfetos, óxidos e haletos) e em menor quantidade a compostos orgânicos. A transferência de cádmio da solução para o sedimento ocorre principalmente através da sorção à matéria orgânica seguida de deposição e através da co-precipitação com óxidos de ferro, alumínio e de manganês. A disponibilidade do cádmio para a biota depende de fatores tais como $\circ \mathrm{pH}$, potencial redox, dureza da água e a presença de outros agentes complexantes. Os efeitos adversos do cádmio sobre a biota incluem mortalidade, redução do crescimento e inibição da reprodução (EISLER, 1985). 


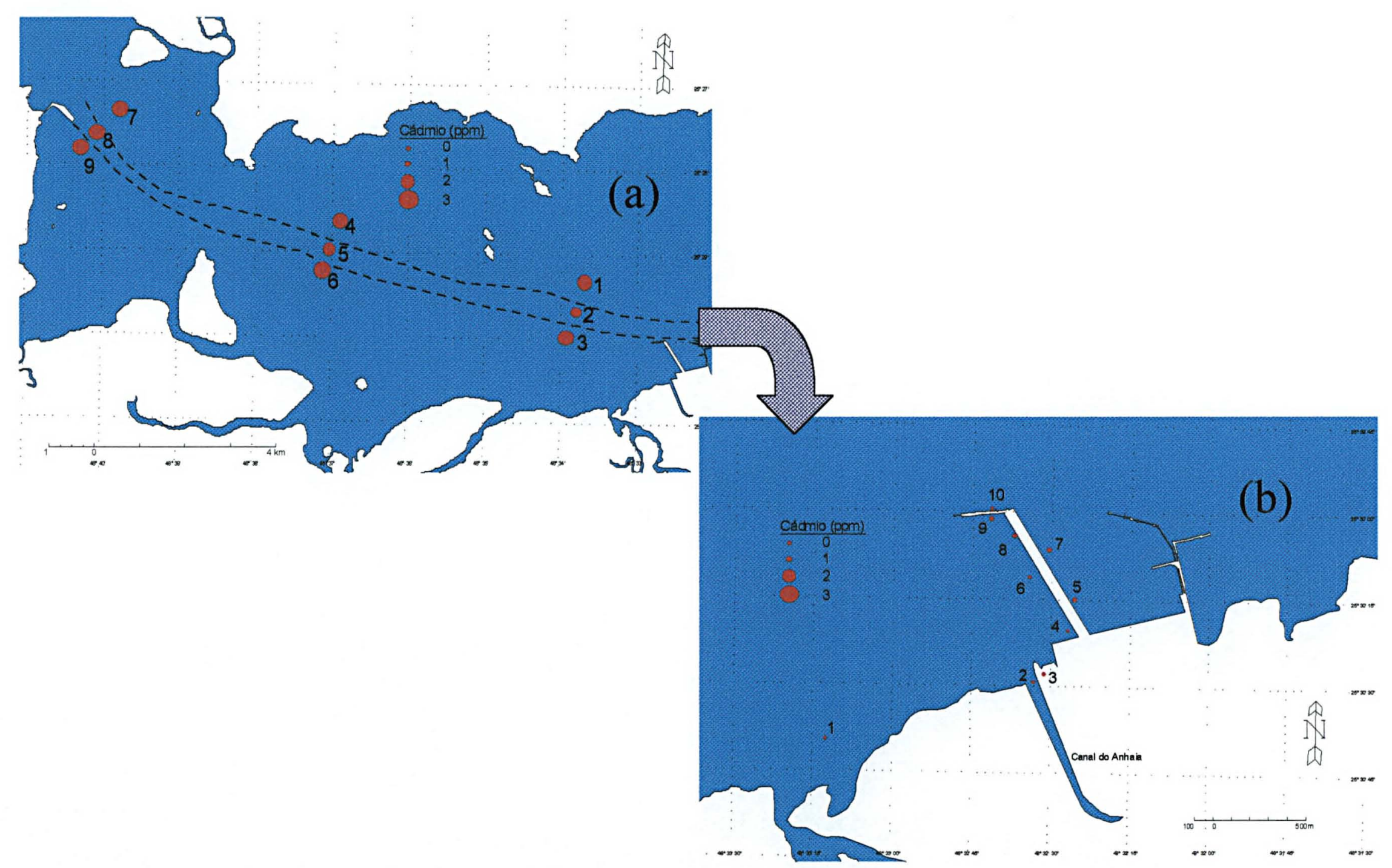

Figura 45 - Distribuição das concentrações de cádmio (ppm) relativo à extração forte no canal de acesso à Baía de Antonina (a) e nas cercanias da indústria de fertilizantes local (b). 


\subsubsection{Chumbo}

As concentrações mais elevadas de chumbo ocorreram na região mediana do complexo estuarino (Figuras 47 e 48), apresentando valores menores tanto na região mais interna quanto na região externa da Baía de Paranaguá. Este panorama é demonstrado nos dois tipos de extrações utilizadas.

O chumbo é usado principalmente na produção de baterias de chumbo-zinco e na fabricação compostos químicos, particularmente em aditivos da gasolina. 0 chumbo também é usado na metalurgia, materiais de construção, equipamentos eletrônicos, plásticos, produtos veterinários, tintas, vidro, tanques de transporte de materiais radioativos, etc. Como para os demais elementos metálicos investigados neste trabalho, as fontes de chumbo para o ecossistema em questão não são conhecidas. 


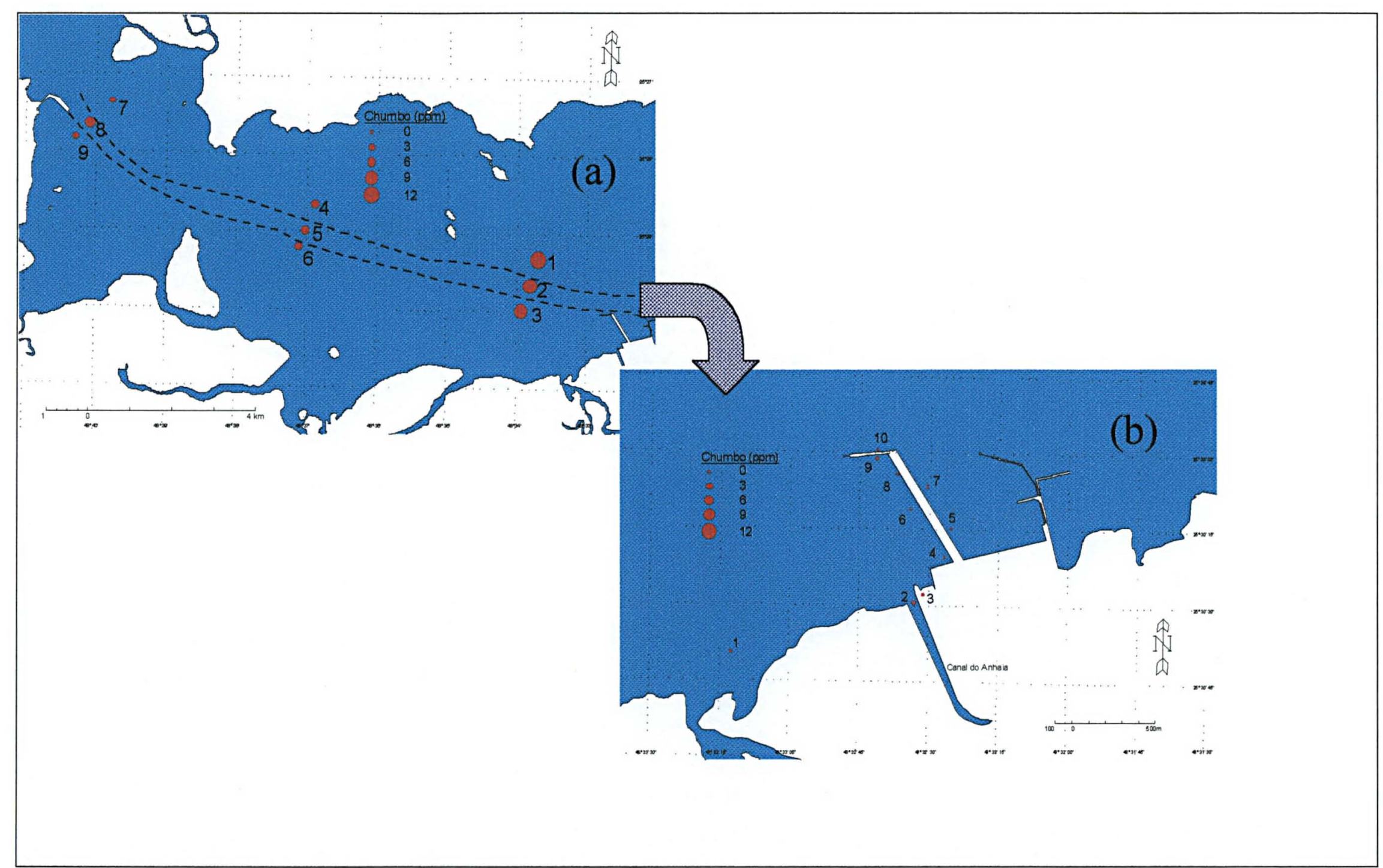

Figura 46 - Distribuição das concentrações de chumbo $(\mathrm{ppm})$ relativo à extração fraca no canal de acesso à Baía de Antonina (a) e nas cercanias da indústria de fertilizantes local (b). 


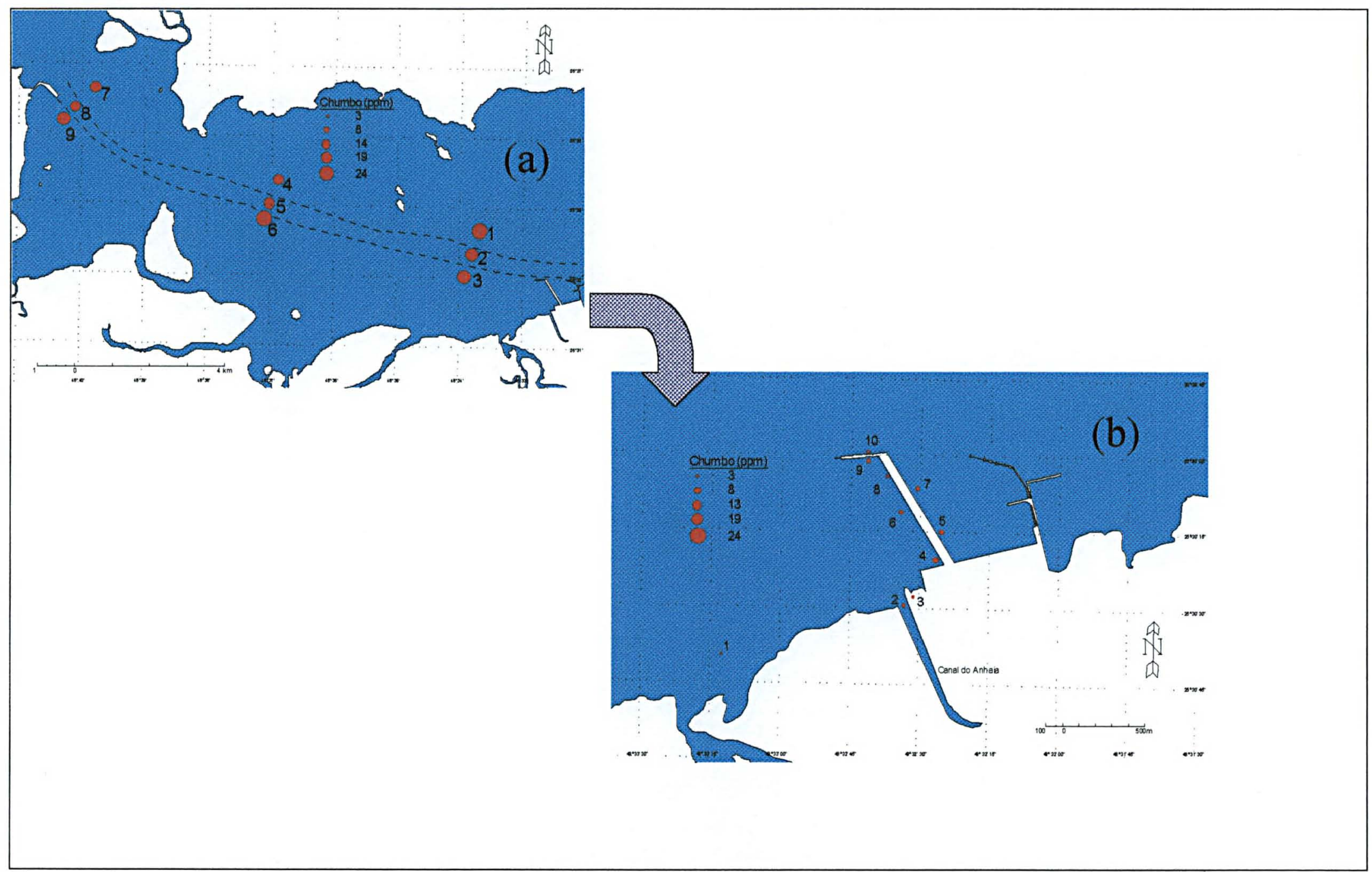

Figura 47 - Distribuição das concentrações de chumbo (ppm) relativo à extração forte no canal de acesso à Baía de Antonina (a) e nas cercanias da industria de fertilizantes local (b). 


\subsection{Legislação ambiental e atividades de dragagem}

\subsubsection{Legislação ambiental}

A legislação brasileira é muito vaga quando se trata especificamente das operações de dragagem. Existe apenas uma norma estabelecida pela Diretoria de Portos e Costas (DPC - órgão vinculado ao Ministério da Marinha) intitulada Norma da Autoridade Portuária n. ${ }^{0} 11$ (NORMAM - 11), de 30 de setembro de 1998, e estabelece que as dragagens poderão ser realizadas com diversos objetivos tais como: estabelecimento inicial de uma determinada profundidade, para manutenção de profundidade de certo local e para execução de aterro.

Esta norma estabelece a documentação que deverá ser entregue pelo interessado à Capitania dos Portos na área de jurisdição do sítio a ser dragado e do sítio de despejo, assim como as exigências feitas pela Diretoria de Hidrografia e Navegação (DHN) para constar em cartas náuticas, no banco de dados da Marinha, ser divulgado em Avisos aos Navegantes e delimitar o local a ser dragado de acordo com o Regulamento para Sinalização Náutica.

Através de Normas de Procedimentos e em consenso com os órgãos locais de controle do meio ambiente, as áreas de despejo poderão ser estabelecidas previamente pela Capitania dos Portos. Caso os órgãos de controle do meio ambiente local não se pronunciem a respeito da área escolhida dentro do prazo de 30 dias, as Capitanias podem estabelecer a área de despejo em caráter precário, comunicando o fato aos citados órgãos.

TORRES (2000) apresentou uma breve síntese sobre a legislação internacional que trata do controle das operações de dragagem e manejo do material dragado. A partir de 1949, quando o governo inglês instituiu a Lei de Proteção da Costa (Coast Protection Act), diversas leis foram criadas em diferentes países para regulamentar este tipo de trabalho e principalmente o que deveria ser feito com o material proveniente das dragagens. Em 1972 foi realizada a primeira etapa da Convenção de Londres sobre a prevenção de poluição marinha pela descarga de lixo e outros resíduos (London Dumping Convention $L D C$ ). O conjunto de normas da LDC prescrevem os passos a serem tomados para se evitar a poluição resultante de descargas no oceano. 
A LDC contém uma série de anexos listando uma grande quantidade de componentes e compostos químicos, os quais são considerados perigosos ou potencialmente perigosos e, portanto, sujeitos a regulamentação. Quando esta regulamentação se refere a dragagens e disposição do material dragado no oceano, os termos envolvidos são os seguintes:

- presença de elementos traço;

- presença em quantidades significativas dos elementos traço;

- verificação da "meia-vida" do componente/composto químico;

- avaliação da toxidade;

- avaliação da persistência;

- verificação de bioacumulação.

Quanto ao manejo do material dragado, a LDC recomenda:

- deve-se fazer amostragens representativas do material dragado;

- avaliar as características gerais do sedimento;

- avaliar quais são os contaminantes principais;

- se necessário, deve-se fazer testes biológicos para mostrar que o material a ser despejado não causará efeitos crônicos ou bioacumulação em organismos marinhos sensiveis.

Maiores detalhes sobre esta convenção podem ser encontrados em Kullenberg (1974 - 75), Davis et al. (1990), Senado Fedaral (1991) e Bray et al.(1997).

No Brasil existem poucos trabalhos que discutem as implicações da contaminação voltadas às atividades de dragagem. Destes, a maioria relaciona-se a modelos hidrodinâmicos, avaliação de impactos de contaminação principalmente por atividades portuárias, e em alguns casos, a análise de custo-benefício de determinados projetos de dragagem (KITZMANN, et al., 2002). 


\subsubsection{Sugestões para monitoramento de dragagem}

Levando em conta os conceitos da LDC, esta parte do trabalho realiza uma abordagem de maneira crítica sobre as leis nacionais, órgãos ambientais, requisitos e análises recomendadas, e quais os tipos de análises e abordagens que, realmente, são eficazes quanto aos problemas ambientais relacionados as atividades de dragagens.

Está em processo final de elaboração, para ser aprovado ainda neste ano, a proposta de resolução do Ministério do Meio Ambiente que dispõe sobre licenciamento ambiental das atividades de dragagem em águas jurisdicionais brasileiras e gerenciamento do material dragado, assim como a Resolução CONAMA para qualidade das águas. Esta resolução define a classificação dos sedimentos quanto às concentrações de diversos poluentes, incluindo elementos metálicos. Isto facilitará o desenvolvimento do gerenciamento das atividades de dragagens e a gestão do material dragado.

Até hoje as análises requisitadas pelos órgãos ambientais em estudos e relatórios ambientais relativos à elementos metálicos, são feitas com 1 tipo de extração, a extração forte (concentração total).

Como ficou demonstrado no presente estudo utilizar-se de somente os dois tipos de extrações para análises de metais proporciona apenas uma compreensão débil da dinâmica dos elementos metálicos e não gera subsídios suficientes para determinar qual a potencialidade poluidora do local e qual o melhor destino para o material dragado. Além da problemática discutida no parágrafo anterior, o órgão ambiental não requisita análises dos elementos metálicos na coluna d'água durante o acompanhamento da pluma de dispersão gerada pela atividade de dragagem, o que impossibilita a verificação e quantificação da partição destes elementos, processo que ocorre pela ressuspensão dos sedimentos, alterações de $\mathrm{pH}$ e condições redox.

USEPA, determina apenas a extração fraca para amostras de sedimento sem a separação da fração fina $(0,062 \mathrm{~mm})$ dos sedimentos. Este fracionamento da granulometria também não é exigido pelos orgãos ambientais brasileiros. 
Os sedimentos de granulometria mais fina possuem os teores mais elevados em matéria orgânica e elementos traço metálicos (FORSTNER \& WITTMAN, 1979). Esta característica é determinada fundamentalmente pelos argilo minerais que são substratos naturais de ligação física e química de substâncias orgânicas e inorgânicas.

Deste modo, tornam-se questionáveis os requisitos exigidos pelos órgãos ambientais para a elaboração de estudos ambientais relacionados à qualidade dos sedimentos e, principalmente, às operações de dragagem.

Algumas opções, em relação aos elementos metálicos, podem ser sugeridas para a melhoria do gerenciamento de dragagens e gestão do material dragado, tais como:

- análise com extração seqüencial ou especiação de metais para sedimentos. Com esta verificação torna-se mais fácil determinar o comportamento dos elementos metálicos, descobrindo em que fração este elemento se encontra, por exemplo na fração trocável, fração adsorvida, fração orgânica, fração carbonática ou fração residual;

- análise de elementos metálicos na coluna d'água, pelo menos durante as etapas de acompanhamento de pluma de dispersão;

- análise na fração fina dos sedimentos;

- análise de carbono orgânico total no sedimento e na coluna d'água;

- monitoramento contínuo de poluentes nos canais de acesso de navegação e bacia de evolução dos terminais portuários.

\subsubsection{Estudo de caso: Acompanhamento das atividades de dragagem no} canal de acesso ao porto de Antonina.

O acompanhamento das atividades de dragagem no canal de acesso ao porto de Antonina permitiu avaliar o quanto as análises de elementos metálicos exigidas pelo órgão ambiental foram representativas na avaliação dos impactos ambientais gerados por tal atividade.

Analisando os resultados obtidos, na primeira etapa deste trabalho, (etapas de acompanhamento da pluma de dispersão e pós-dragagem) verificou-se, em 
alguns casos, que muitos elementos analisados apresentaram concentrações mais elevadas na campanha da pluma do que na de pós-dragagem. Os grupos principais, formados através da análise de agrupamento (Figura 12), possibilitam a interpretação de que a atividade de dragagem pode ter influenciado todos as seções, inclusive a que não sofreu processo de dragagem. Este fato pode ser relacionado com o acompanhamento da pluma de dispersão, que na maioria dos casos apresentou concentrações mais elevadas. Com a falta das análises de especiação química e análises na coluna d'água desses elementos tornou-se difícil a compreensão dos dados obtidos, pois não foi possível obter o comportamento que estes elementos metálicos tiveram durante as atividades de dragagem.

É esperado que após a retirada de uma camada de sedimento, caso não tenha ocorrido algum tipo de poluição na história do local, que os teores de elementos metálicos diminuam, pois o aumento das concentrações nas camadas superiores é diretamente relacionadas com o início das atividades industriais no local. Porém, isto não ocorreu nas atividades de pós-dragagens na Baía de Antonina. O único elemento metálico analisado que que apresentou este comportamento, descrito acima, foi o cádmio, onde em todas as estações apresentou concentrações menores na fase de pós-dragagem em relação a fase de pré-dragagem (Figura 11). Segundo os resultados obtidos, as atividades de dragagem exerceram um efeito benéfico na qualidade do sedimento em relação a este metal. Porém, devemos ressaltar que apesar do decréscimo observado, as concentrações na fase de Pós-dragagem permaneceram acima do limite crítico.

Os outros elementos metálicos analisados durante a atividade de dragagem mostraram comportamento diferenciado, com concentrações mais elevadas nas fases de pós-dragagem e de acompanhamento da pluma de dispersão, tanto na extração forte quanto na extração fraca (ver Figuras 5 a 11).

Isto fortalece ainda mais a discussão sobre como são conduzidas as análises ambientais exigidas pelos órgãos ambientais, que geram um diagnóstico ineficiente sobre a qualidade do ambiente, principalmente em relação aos contaminantes presentes nos sedimentos. 


\section{Considerações finais}

A distribuição dos elementos metálicos e metalóide (arsênio) no Complexo Estuarino de Paranaguá ficou caracterizada através dos mapas de proporcionalidade. Os resultados obtidos evidenciaram os principais contaminantes presentes nos sedimentos superficiais, alertando para problemática ambiental, a qual deverá ser considerada nos futuros trabalhos desenvolvidos na região pelos órgãos ambientais.

Quanto à fonte poluidora para estes elementos investigados não foi possível sua determinação. Pode-se inferir a influência de despejos domésticos e industriais na Baía de Paranaguá para alguns dos elementos, como por exemplo o arsênio. Este elemento possui um incremento bastante significativo próximo a cidade de Paranaguá, podendo ser relacionado com as rochas fosfatadas utilizadas na fabricação de fertilizantes. A Baía de Antonina foi, provavelmente, influenciada por contaminações passadas devido à minerações ocorridas na Serra do Mar. A presença, por exemplo, do elemento mercúrio nesta região no sedimento superficial pode ser relacionada com a ressuspensão e posterior deposição gerada por atividades de dragagem.

Também ficou demonstrado a influência da atividade de dragagem, quanto à esses elementos, gerada dentro de um ambiente estuarino. Este tipo de atividade, com o local de despejo para o material dragado dentro do corpo estuarino, influencia uma grande área, principalmente os locais mais próximos da região dragada e de despejo.

Outra consideração, em relação à atividade de dragagem, é o comportamento diferenciado apresentado pelos diversos elementos analisados quando comparadas as fases de pré-dragagem, pluma de dispersão e pósdragagem, já que apenas para o elemento cádmio ocorreu uma diminuição da concentração na fase de pluma de dispersão e pós-dragagem. Os demais elementos apresentaram, geralmente, concentrações mais elevadas durante a fase de acompanhamento da pluma de dispersão. Sendo assim, a atividade de dragagem e despejo promoveram a remobilização dos elementos analisados e, 
consequentemente, modificações parcial ou total na distribuição dos elementos metálicos nas áreas investigadas.

A análise dos resultados mostrou que, exceto o elemento cádmio, os demais elementos analisados apresentaram concentrações mais elevadas na zona de máxima turbidez, definida por NOERNBERG (2001) entre as llhas Gererês e o Porto de Paranaguá (Figuras 38 - 47). Esta zona de mistura, denominada de máxima turbidez, encontra-se mais a jusante com o aumento do fluxo fluvial e maré de vazante, e mais a montante com a amplitude da maré de enchente. É caracterizada pela elevada concentração de partículas em suspensão, muito superior às concentrações encontradas a montante e a jusante. Isto acontece pois existem condições ótimas para floculação à medida que a descarga fluvial encontra a cunha de intrusão salina, o que aumenta o fluxo de deposição. Por outro lado, a corrente salina junto ao fundo pode ressuspender os sedimentos, liberando-os de novo para a coluna d'água, possivelmente desagregados, repetindo-se o processo.

As exigências efetuadas pelos órgãos ambientais para análises de elementos metálicos em sedimentos não são suficientes para o desenvolvimento do diagnóstico ambiental quanto às atividades de dragagem. É necessário o desenvolvimento de um monitoramento contínuo de contaminantes nos sedimentos em áreas portuárias e em prováveis regiões de despejo do material dragado, que esperamos, ser cumprida através da resolução CONAMA para sedimentos, em processo de aprovação, e pela Agenda Ambiental Portuária. Outra esperança é que a iniciativa privada localizada em terminais portuários tenha consciência de realizar medidas mitigadoras, as quais trazem infinitas recompensas, tanto para a própria empresa quanto para a qualidade ambiental, no qual o homem está inserido. 


\section{REFERÊNCIAS BIBLIOGRÁFICAS}

APPAVCEM 1997. Relatório consolidado do convênio APPA/CEM. Curitiba. Inédito.

ANGULO, R.J.; 1992. Geologia da planície costeira do Estado do Paraná. Instituto de Geociências, Universidade de São Paulo, São Paulo, Tese de Doutorado, 334p.

BAISCH, P.R.; 1994 Les oligo-éléments métalliques du système fluviolagunaire dos Patos (Brésil): flux et devenir. Bordeaux, (Thèse de Doctorat Université de Bordeaux, França), n. 1136, 231p. (Inédito).

BAISCH, P.R.; 1997 Geoquímica dos sedimentos do estuário da Lagoa dos Patos: elementos metálicos e matéria orgânica. Relatório Técnico Final / Setor de Geoquímica - EIA/RIMA - DEPRC/FURG. Rio Grande: Laboratório de Oceanografia Geológica.. 52p.

BAUMGATEN, M. G. Z, J. M. BARROS, L. F. H. NIENCHESKI 1996. Manual de análises em oceanografia química. Ed. Furg, Rio Gande, 132p.

BELZUNCE, M.J. 2001; Accumulation of Organic Matter, Heavy Metals and Organic Compounds in Surface Sediments along the Nervión Estuary (Northen Spain). Marine Pollution Bulletin Vol. 42, No. 12, pp.1407-1411.

BENNETT, J.R. The physics of sediment transport, resuspension and deposition. Hydrobiologia, v.149, p. 5-12, 1987

BHATTACHARYA, P. et al., 2001. Metal contamination at a wood preservation site: characterisation and experimental studies on remediation. The Science of the Total Environment 290: 165-180.

BHATTACHARYA, P., et al. 1997. Occurrence of arsenic contaminated grounwater in alluvial aquifers from Delta Plains, Eastern India: options for safe drinking water supply. Int Jour Water Res Management 13(1): 79-92.

BHUMBLA, D.K. and KEEFER, R.F. 1994. Arsenic mobilisation and bioavailability in soils. In: Nriagu JO, editor. Arsenic in the environment, part I: cycling and characterisation. New York: John Wiley, 51-82.

BIGARELLA, J. J.; BECKER, R. D.; MATOS, D. J.; WERNER, A. (1978). A Serra do Mar e a Porção Oriental do Estado do Paraná. Secretaria de Estado do Planejamento, Governo do Paraná. 248 p.

BIGARELLA, J. J.; ALESSI, A. H.; BECKER, R. D.; DUARTE, G. M. (1970). Natureza dos sedimentos de fundo das Baías de Paranaguá e Antonina. Instituto de Biologia e Pesquisas Tecnológicas, $n^{\circ}$ 15, Curitiba, PR, Brasil. 
BOSTROM, K.; VALDES, S. 1969. Arsenic in ocean floors. Lithos 2 p. 351-360. BRAY, R.N., BATES, A.D. e LAND, J.M. 1997. Dredging, a Handbook for Engineers. John Wiley \& Son, Inc. Second edition. New York. 434p.

BUCHMAN, M.F., 1999. NOAA Screening Reference Tables, NOAA HASMAT. Report 99-1, Seattle WA, Coastal Protection and Restoration Division, National and Amospheric Administration, 12p.

CCREM (Canadian Council of Resource and Environment Minister) 1987. Canadian Water Quality Guidelines. Task Force on Water Quality Guidelines. Ottawa, Canada.

CONSELHO NACIONAL DO MEIO AMBIENTE (1984 À 1991). Resolução do CONAMA. $4^{\circ}$ edição. Imprensa Nacional, Brasília.

CULLEM, W.R. and REIMER, K.J., 1989. Arsenic speciation in the enviroment. Chem. Rev. 89: 713-754.

CRECELIUS, E.A.; BOTHNER, M.H.; CARPENTR, R. 1975. Geochemistry of arsenic, antimony, mercury and related elements in sediments of Puget Sound. Environ. Sci. Tech., v. 1, p. 325-333.

DAVIS, J.D.; Macknight, S. e IMO staff. 1990. Environmental Considerations for Port and Harbor Developments. World Bank Technical Paper, no. 126. 83p.

DELAUNE, R.D. \& SMITH, C.J. 1985; Release of nutrients and metals following oxidadation of freshwater and saline sediments. Journal of Environmental Quality, v.14, n.2, p.164-168.

EISLER, R. 1985. Cadmium hazards to fish, wildlife, and invertebrates. A synoptic review. Contaminant Hazard Reviews Report No. 2. U.S. Department of rhe Interior. Fish and Wildlife Service. Patuxent Wildlife Research Center. Laurel, Maryland.

FARMER, J.G. and LOVELL, M.A., 1986. Natural enrichment of arsenic in Loch Lomond sediments. Geochim. Cosmochim. Acta, 50: 2059-2067.

FORSTNER, U. \& WITTMAN, G. Metal Pollution in the Aquatic Environment. Springer. Berlin Heidelberg New York, 1979. 486 p.

FORSTNER, $U$. Changes in metal mobilities in aquatic and terrestrial cycles. In: PATTERSON, V.W. \& PASSINO (eds.). Metals speciation, separation and recovery. Lewis, Chelsea, MI. 1987. p.3-26.

GALBA, J.; POLACEK, S. 1973. Solutions of arsenates under kinetic conditions in selected soil types. Acta Fytotech, v. 28, p. 187-197. 
HANSEN, D. V.; RATTARAY JÚNIOR, M. 1965. Gravitational circulation in straits and estuaries. J. Mar. Res., New Haven, v. 23, p. 104-122.

HAYNES, D. et al. 2002. Trace metals in sediments from Torres Strait and the Gulf of Papua: concentrations, distribution and water circulation patterns. Marine Pollution Bulletin. Vol. 44. pp. 1296-1313.

HARADA, M. 1978. Methyl mercury poisoning due to environmental contamination ("Minimata Disease"). In: Toxicity of Heavy Metals in the Environment. Oehme, F. W., Ed., Marcel Dekker, NY, p.261.

JAAGUMAGI, R. 1990. Development of the Ontario provincial sediment quality guidelines for arsenic, cadmium, chromium, copper, iron, lead, manganese, mercury, nickel and zinc. Water Resources Branch. Environment Ontario. Toronto, Ontario 10pp. + app.

KITZMANN, D.I.S.; CALLIARI, L.J.; ASMUS, M.L. \& TAGLIANI, C.R. 2002. Gerenciamento Ambiental Portuário. $1^{a}$ ed., pasta com 6 módulos. 15 a 20 de setembro de 2002. Paranaguá - PR. (PNCAP/FURG/TRAIN-SEA-COAST BRASIL).

KJERFVE, B. 1990. Manual for investigation of hydrological processes in mangrove ecosystems. UNESCO/UNDF Regional Project "Mangrove Ecosystems in Asia and the Pacific" (RAS/79/002 e RAS/86/120), 79p.

KNOPPERS, B. A.; BRANDINI, F. P.; THAMM, C. A. (1987). Ecological studies in the Bay of Paranaguá. II. Some physical and chemical characteristics. Nerítica, Curitiba, v. 2, n. 1, p. 1-36.

KOBAYASHI, J. 1970. Relation between Itai-Itai disease and the pollution of river water by cadmium from mine. In: Int. Conf. of Advances in Water Pollution Research, Vol. 1, Jenkins, S. H. Ed., Pergamon Press, Oxford.

KOLM, H.E.; MACHADO, E.C. et al., 2002. Avaliação dos impactos decorrentes da construção de um píer pela FOSPAR - Fertilizantes Fosfatados do Paraná S.A. Pontal do Paraná: UFPR-CEM-FOSPAR. 184 p. Relatório Técnico.

KULLENBERG, G.E.B. 1974-75. Ocean dumping sites. Ocean Management, vol. 2, pp.189-209.

LANA, P. C.; MARONE, E.; LOPES, R.M.; MACHADO, E.C. (2000). The subtropical estuarine complex of Paranaguá Bay, Brazil. In: Ecological Studies, Coastal Marine Ecosystems of Latin America. Springer-Verlag Berlin Heidelberg, 144, p. 131-145. 
LAUTERT, L.F.C. 1999. Diagnóstico sócio-natural da porção sul do município de Paranaguá - PR. Universidade Estadual Paulista, Rio Claro - SP, Dissertação de Mestrado, p. 121.

LEE, C-L. 1998; Characterization and Distribution of Metals in Surficial Sediments in Southwestern Taiwan. Marine Pollution Bulletin, Vol. 36. No. 6. pp. $464-471$.

LESSA, G.C.; ANGULO, R.J.; GIANNINI, P.C.; ARAÚJO, A.D. 2000. Stratigraphy and Holocene evolution of a regressive barrier in south Brazil. Marine Geology. n. 165 (1-4), p. 87-108.

LOMBARDI, A.T.; VIEIRA, A.; SARTORI, L.A. 2002. Musselaginous capsule adsorption and intra cellular uptake of copper by Kirchmeriella aperta (Chlorococcales). Journal of phycology, Vol. 38 pp.332-337.

LORING, D.H. et al. 1995. Arsenic, trace metals, and organic micro contaminants in sediments from the Pechora Sea, Russia. Marine Geology. Vol. 128. pp. 153-167.

MacDONALD, D.D. 1994. Approach to the assessment of sediment quality in Florida coastal waters. Development and Evaluation of Sediment Quality Assessment Guidelines, Florida Department of Environment Protection Office of Water Policy, U.S.A., Vol. 1, 140p.

MANNING, B.A. and GOLDBERG, S., 1996. Modelling competitive adsorption of arsenate with phosphate and molybdate on oxide minerals. Soil Sci Soc J, 60: 121-131.

MANTOVANELLI, A. 1999. Caracterização da dinâmica hídrica e do material particulado em suspensão na Baía de Paranaguá e em sua bacia de drenagem. Curitiba. 146 f. Dissertação (Mestrado em Geologia Ambiental) - Setor de Ciências da Terra, Universidade Federal do Paraná.

MARONE, E.; JAMIYANAA, D. 1997. Tidal characteristics and a variable boundary numerical model for the M2 tide for the Estuarine Complex of the Bay of Paranaguá, PR, Brazil. Nerítica, v. 11 (1-2), p. 95-107

MASSCHELEYN, P.H., et al. 1991. Arsenic and selenium chemistry as affected by sediment redox potencial and pH. Environ. Qual. 20: 522-527.

MIRANDA, L.B. 1996. Cinemática e dinâmica de estuários. São Paulo: Instituto Oceanográfico da USP (IO827), v. 1, 360 p.

MOORE, J.W. and RAMAMOORTHY, S. 1984. Heavy metals in natural waters. Applied Monitoring and Risk Assessment. Springer Verlag, New York, NY, USA. 
MOORE, J.N. et al. 1988. Partitioning of arsenic and metals in reducing sulfidic sediments. Environ. Sci. Technol. 22: 432-437.

NAS - NATIONAL ACADEMY OF SCIENCES, 1977. Drinking water and health. Vol. 1, National Academy of Sciences, Washington, D.C., U.S.A.

NOERNBERG, M. A. 2001. Processos morfodinâmicos no Complexo Estuarino de Paranaguá: um estudo utilizando dados Landsat-TM e medições in situ. Curitiba - PR. 118 f. Tese (Doutorado em Geologia Ambiental Departamento de Geologia), Setor de Ciências da Terra da Universidade Federal do Paraná. Em preparação

NEFF, J.M., 1996. Ecotoxicology of arsenic in the marine environment. Environment Toxicology and Chemistry, Vol. 16, No. 5, pp. 917-927.

ODRESKI, L.L.R. 2002. Evolução sedimentar e batimétrica da Baía de Antonina, PR. Dissertação de mestrado apresentada ao Curso de Pós-Graduação em Geiologia - UFPR, 79p., inédito.

PETROBRÁS. 1997. Estudos ambientais em áreas oceânicas e costeiras no sul do Brasil. 1 CD - ROM.

RIEDEL, G.F. et al., 1989. The role of three species os benthic invertebrates in the transport of arsenic from contaminated estuarine sediment. J. Exp. Mar. Biol. Ecol. 134: 143-153.

SADIQ, M. et al., 1983. Environmental bahavior of arsenic in soils: theoretical. Water Air Soil Pollut, 20: 369-377.

SALOMONS, W. \& FORSTNER, U. Metals in the hydrocycle. Berlin: SpringerVerlag $1984.349 p$.

SALOMONS, W. et al. Behaviour and impact assessment of heavy metals in estuarine and coastal zones. In: SEELIGER, U.; LACERDA, L.D. \& PATCHINEELAM, S.R. (eds.). Metals in Coastal Environnments of Latin America. Berlin: Springer-Verlag, p.157-193, 1988.

SEMA (1980). Avaliação dos projetos de metais pesados. Relatório SEMAMINTER, Brasilia.

SENADO FEDERAL. 1991. Meio Ambiente - Legislação. Subsecretaria de Edições Técnicas. Brasília. 882p.

SHUMILIN, E.; PÁEZ-OSUNA, F.; et al. 2001. Arsenic, antimony, selenium and other trace elements in sediments of the La Paz Lagoon, Peninsula of Baja, California, Mexico. Marine Pollution Bulletin, Vol. 42, No. 3, pp. 174-178. 
SOARES, C.R.; LESSA, G.C.; GOTTARDI NETO, A.; RIESEMBERG, C.E.; SILVA, C.B. 1996. Caracterização da distribuição dos sedimentos de fundo das baías de Paranaguá e Antonina, Estado do Paraná. In: Congresso Brasileiro de Geologia, 39., Salvador. Anais: SBG. Vol. 3, p. 390-396.

SOARES, C.R.; ANGULO, R.J. \& LESSA, G.C. 1997. Morfodinâmica dos ambientes atuais, evolução da planície durante o Quaternário e problemas de erosão costeira. VI Congresso da Associação Brasileira de Estudos do Quaternário. Plubicação Especial $n^{\circ} 2$. Roteiro da Excursão ao Litoral do Estado do Paraná, 127p.

STRICKLAND J. L. H. \& PARSONS T. R. (1972). A Practical Handbook of Seawater Analysis. Bull. Fish Res. Board Can., 167 p.

THOMAS, R.L. A protocol for the selection of process oriented remedial options to control the in situ sediment contaminants. Hydrobiologia, v.149, p.247-258, 1987.

TORRES, R.J. 2000. Uma Análise Preliminar dos Processos de Dragagem do Porto de Rio Grande, RS. Engenharia Oceânica, Fundação Universidade Federal do Rio Grande, Rio Grande, Dissertação de Mestrado 180 pp.

USEPA - United States Environmental Protection Agency. 1992. Evaluating Environmental Effects of Dredged Material, Management Alternatives, a Technical Framework. EPA 842-B-92-008. Office of Water (4504F). Washington. $79 p$.

VALLEE, B.L. and ULMER, D.D., 1972. Biochemical effects of mercury, cadmium and lead. A Rev. Biochem., Vol. 41, pp. 91-128. 